Article

\title{
Novel Selective Estrogen Receptor Ligand Conjugates Incorporating Endoxifen-Combretastatin and Cyclofenil-Combretastatin Hybrid Scaffolds: Synthesis and Biochemical Evaluation
}

\author{
Patrick M. Kelly ${ }^{1}$, Niall O. Keely ${ }^{2}$, Sandra A. Bright ${ }^{3}$, Bassem Yassin ${ }^{2}$, Gloria Ana ${ }^{1}$, \\ Darren Fayne $^{3}$, Daniela M. Zisterer ${ }^{3}$ and Mary J. Meegan ${ }^{1,2, *}$ \\ 1 School of Pharmacy and Pharmaceutical Sciences, Trinity Biomedical Sciences Institute, 152-160 Pearse \\ Street, Trinity College Dublin, Dublin 2, Ireland; kellyp9@tcd.ie (P.M.K.); anag@tcd.ie (G.A.) \\ 2 School of Pharmacy and Pharmaceutical Sciences, Trinity College Dublin, Dublin 2, Ireland; \\ nkeely@tcd.ie (N.O.K.); bassem76@yahoo.com (B.Y.) \\ 3 School of Biochemistry and Immunology, Trinity Biomedical Sciences Institute, 152-160 Pearse Street, Trinity \\ College Dublin, Dublin 2, Ireland; brights@tcd.ie (S.A.B.); FAYNED@tcd.ie (D.F.); dzistrer@tcd.ie (D.M.Z.) \\ * Correspondence: mmeegan@tcd.ie; Tel.: +353-1-896-2798
}

Received: 9 July 2017; Accepted: 17 August 2017; Published: 31 August 2017

\begin{abstract}
Nuclear receptors such as the estrogen receptors (ER $\alpha$ and $E R \beta)$ modulate the effects of the estrogen hormones and are important targets for design of innovative chemotherapeutic agents for diseases such as breast cancer and osteoporosis. Conjugate and bifunctional compounds which incorporate an ER ligand offer a useful method of delivering cytotoxic drugs to tissue sites such as breast cancers which express ERs. A series of novel conjugate molecules incorporating both the ER ligands endoxifen and cyclofenil-endoxifen hybrids covalently linked to the antimitotic and tubulin targeting agent combretastatin A-4 were synthesised and evaluated as ER ligands. A number of these compounds demonstrated pro-apoptotic effects, with potent antiproliferative activity in ER-positive MCF-7 breast cancer cell lines and low cytotoxicity. These conjugates displayed binding affinity towards ER $\alpha$ and ER $\beta$ isoforms at nanomolar concentrations e.g., the cyclofenil-amide compound 13e is a promising lead compound of a clinically relevant ER conjugate with $\mathrm{IC}_{50}$ in MCF-7 cells of $187 \mathrm{nM}$, and binding affinity to $\mathrm{ER} \alpha\left(\mathrm{IC}_{50}=19 \mathrm{nM}\right)$ and $\mathrm{ER} \beta\left(\mathrm{IC}_{50}=229 \mathrm{nM}\right)$ while the endoxifen conjugate $16 \mathrm{~b}$ demonstrates antiproliferative activity in MCF-7 cells $\left(\mathrm{IC}_{50}=5.7 \mathrm{nM}\right)$ and binding affinity to $\mathrm{ER} \alpha\left(\mathrm{IC}_{50}=15 \mathrm{nM}\right)$ and $\mathrm{ER} \beta\left(\mathrm{IC}_{50}=115 \mathrm{nM}\right)$. The ER binding effects are rationalised in a molecular modelling study in which the disruption of the ER helix-12 in the presence of compounds 11e, 13e and 16b is presented These conjugate compounds have potential application for further development as antineoplastic agents in the treatment of ER positive breast cancers.
\end{abstract}

Keywords: tumour targeting conjugates; selective estrogen receptor modulators; combretastatin A-4(CA-4); endoxifen; cyclofenil; estrogen receptor ligands; hormone-dependent breast cancer; apoptosis

\section{Introduction}

Breast cancer is the most common cancer in women worldwide, affecting one in eight women and representing a significant cause of cancer death in women. Incidence rates are increasing steadily, with nearly 1.7 million new cases diagnosed in 2012 worldwide [1]. The majority of early stage breast cancers are hormone-dependent and patient prognosis is good. However, when the breast cancer is or becomes hormone-independent then prognosis is poor. About $5 \%$ of breast cancers, denoted BRCA-1 and BRCA-2, are considered hereditary [2]. The two nuclear estrogen receptors (ER $\alpha$ and ER $\beta$ ) 
mediate the biological effects of the estrogen hormones $[3,4]$. These receptors are widely distributed in the body and are attractive therapeutic targets for diseases such as breast cancer and osteoporosis $[5,6]$. These receptors differ in their tissue distribution and in their ability to bind ligands. ER $\alpha$ is mainly found in uterus, bone, cardiovascular tissue and liver, and is the predominant receptor expressed in breast tumours [7]. ER $\alpha$ is also recognised to be mainly responsible for the effects of estrogen in hormonal replacement therapy. ER $\beta$ is expressed in many tissues and is the predominant ER in vascular endothelium, bone and male prostate tissues. The role of ER $\beta$ in the progression of breast cancer is still under investigation; ER $\beta$ expression has been reported to have a potentially protective effect on ER $\alpha$ promoted hyperproliferation [8-12]. The two ER subtypes differ significantly in size: 595 amino acids in ER $\alpha$ compared to 485 amino acids in ER $\beta$. The conservation of amino acid sequence in the ligand binding sites of $E R \alpha$ and $E R \beta$ is only $59 \%$, with the most notable differences in the ligand binding pocket (LBP) being replacement of Met412 and Leu384 in ER $\alpha$ with Ile and Met in ER $\beta$ [13-15]. Approaches to the discovery of selective estrogen receptor modulators (SERMs) rely on ER binding and cell-based estrogen response element-driven assays to identify compounds that are osteoprotective and antiproliferative in breast and uterine tissue. Estrogens are known to have tissue selective effects, and there is considerable interest in the therapeutic use of SERMs. These compounds act as ER antagonists in some tissues, e.g., uterus and breast, while functioning as ER agonists in the cardiovascular system, bone and brain.

A number of SERMs are currently in clinical use or clinical trials [16], including raloxifene [17] and tamoxifen [18,19], which are in widespread use for the prevention of osteoporosis and treatment of hormone-dependent breast cancer, respectively [4,20] (Figure 1). The indole-containing compound bazedoxifene [21] is also available for the treatment of osteoporosis and hot flushes in postmenopausal women, while ospemifene is approved for vaginal dryness [22]. Use of tamoxifen has been linked to increased risk of thrombosis and endometrial cancer. Also as the disease progresses, the effectiveness of drugs such as tamoxifen decreases as the tumours can become more resistant and less hormone dependent. The clinical success of tamoxifen and raloxifene has driven the search for new SERMs with applications as multifunctional drugs. Selective estrogen receptor downregulators (SERDs) such as fulvestrant reduce ER $\alpha$ protein levels and block ER activity. Fulvestrant is in clinical use for the treatment of postmenopausal ER positive breast cancer (locally advanced or metastatic) and is indicated for disease progression or relapse on adjuvant anti-estrogen therapy [23] (Figure 1). The acrylic acid GW5638 and the related hydroxylated GW7604, are identified as SERDs with similar core ligand triarylethylene structure to tamoxifen, but the basic side chain is replaced by an acrylic acid. GW5638 demonstrates agonist effects in bone but acts as an antagonist in breast tumours [24,25] (Figure 1).

Many approaches have been investigated to improve the selectivity of drugs used for chemotherapy by targeting tumour cells and associated receptors. The metabolites of tamoxifen, e.g., 4-hydroxytamoxifen, endoxifen and norendoxifen (Figure 1) possess potent antiestrogen activity [26]. Endoxifen is a potent antiestrogen, with strong ER affinity, degrades ER and interestingly demonstrates aromatase inhibitory activity [27-29]. In this research, the endoxifen molecule provides the ER targeting scaffold to be synthesised having selectivity to target the ER over-expressed in ER positive breast cancer cells, such as MCF-7 cells. The use of the endoxifen scaffold in the novel conjugate design should allow the selectivity to deliver a cytotoxic agent directly to the tumour site. Previous studies by Burke [30] and Keely [31] have demonstrated the use of the antiestrogen endoxifen for the conjugation of estradiol and cytotoxic drugs such as doxorubicin. The high affinity nonsteroidal ER ligand cyclofenil diphenol (F6060) [32,33] is also selected in the present work as an ER targeting core ligand for development of a novel conjugate design. Cyclofenil diphenol (F6060) and its derivatives have high binding affinity for ER, with mixed agonist-antagonist activity typical for a SERM such as tamoxifen or raloxifene [33]. F6060 and analogues have been shown to inhibit proteoglycan synthesis [34], similar to tamoxifen. Seo et al. reported good ER-subtype binding and selectivity in a number of cyclofenil analogues [33]. 


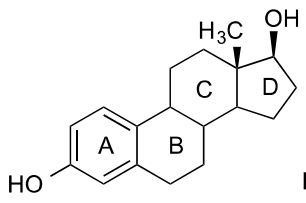

Estradiol<smiles>CCCC1CCc2cc(O)ccc21</smiles>

$\overline{\mathrm{H}} \mathrm{H}$

$\mathrm{OH}$<smiles>CCCCCCCCCCS(=O)CCCC(F)(F)C(F)(F)F</smiles>

Fulvestrant<smiles>COc1ccc(-c2cc(OC)c(OC)c(OC)c2)cc1O</smiles>

Combretastatin A-4: $\mathrm{R}=\mathrm{H}$ Fosbretabulin $\mathrm{R}=\mathrm{PO}_{3} \mathrm{Na}_{2}$<smiles>[R3]c1ccc(C(=C(CC)c2ccccc2)c2ccc(OCCN([R])[R])cc2)cc1</smiles>

Tamoxifen: $\mathrm{R}_{1}=\mathrm{R}_{2}=\mathrm{CH}_{3}, \mathrm{R}_{3}=\mathrm{H}$ 4-Hydroxytamoxifen: $\mathrm{R}_{1}=\mathrm{R}_{2}=\mathrm{CH}_{3}, \mathrm{R}_{3}=\mathrm{OH}$ Endoxifen: $\mathrm{R}_{1}=\mathrm{H}, \mathrm{R}_{2}=\mathrm{CH}_{3}, \mathrm{R}_{3}=\mathrm{OH}$ Norendoxifen $\mathrm{R}_{1}=\mathrm{R}_{2}=\mathrm{H}, \mathrm{R}_{3}=\mathrm{OH}$<smiles>[R]c1ccc(C(=C(CC)c2ccccc2)c2ccc(C=CC(=O)O)cc2)cc1</smiles>

GW5638 $\mathrm{R}=\mathrm{H}$ GW7604, $\mathrm{R}=\mathrm{OH}$,<smiles>OCCOc1ccc(C(=C(CCCl)c2ccccc2)c2ccccc2)cc1</smiles>

Ospemifene<smiles>Cc1c(-c2ccc(O)cc2)n(Cc2ccc(OCCN3CCCCCC3)cc2)c2ccc(O)cc12</smiles>

Bazedoxifene

Figure 1. Estradiol, selected ER antagonists and combretastatin A-4.

Typical conjugates are bifunctional molecules containing covalently linked ligands or pharmacophores which are designed to produce selectivity in targeting the intracellular ER [35,36]. The objectives of the conjugate design investigated in the current research are to produce conjugates capable of the delivery of cytotoxic agents to the ER positive breast cancer tumour cell, and to increase the selectivity of these cytotoxic agents which should result in less toxicity and increased efficacy. We also wished to produce ER antagonists through inclusion of the additional, bulky linker-cytotoxic agent moiety of the conjugate structure and with the possibility of achieving a dual-action activity i.e., ER antagonism and antimitotic activity.

ER ligand conjugates of cytotoxic agents, photodynamic therapeutic agents and radioligands which deliver cytotoxic agents have been reported [31,37]. We have previously reported stable conjugates of endoxifen (a tamoxifen metabolite and ER antagonist) with DNA alkylating agents, aromatase inhibitors, COX2 inhibitors and antitubulin compounds which demonstrate antiproliferative and ER binding effects [38]. We have also reported related conjugates based on the 2-arylindole scaffold structure which selectively target the ER in hormone dependent breast cancers [39]. Many previously reported ER conjugates have included ER agonist ligands such as estradiol as the ER ligand component $[37,40]$. However, in the present work we have incorporated ER antagonistic ligands such as endoxifen [27] and the novel cyclofenil based ER antagonist in the designed structures. 
Combretastatin A-4 (CA-4) (Figure 1), a potent antimitotic agent isolated from the bark of the South African tree Combretum caffrum. It exhibits potent antitubulin effects by binding to tubulin at the colchicine binding site. CA-4 demonstrates cytotoxicity against a wide range of human cancer cell lines, including those that are multi-drug resistant [41-43]. However, because of poor water solubility of CA-4, a more water-soluble combretastatin A4-phosphate CA-4P (fosbretabulin, Figure 1) was synthesized and is currently under investigation in combination with pazopanib in a Phase $1 \mathrm{~b}$ and Phase II study for the treatment of advanced recurrent ovarian cancer [44]. Many synthetic analogues of combretastatin A4 have been developed [45]. Among the various hybrids and conjugates of combretastatin A-4 which have been reported are hydrophobic combretastatin A-4 conjugated with hydrophilic irinotecan to form amphiphilic molecules (in which an azobenzene bond imparts hypoxia sensitivity) which can self assembly into nanoparticles for breast cancer synergistic therapy [46]. High-molecular weight conjugates of combretastatins with polyethylene glycol have been reported (comprising a block copolymer of a polyethylene glycol moiety and a polymer moiety having two or more carboxylic acid groups), in which a carboxylic acid group of the polymer moiety is linked to a hydroxyl group of combretastatins via an ester [47]. Combretastatin A-4 conjugated anti-angiogenic micellar drug delivery systems using dendron-polymer conjugates are also reported [48]. CA-4 analogues have been introduced onto steroid scaffolds to explore proapoptotic effects [49].

In the present work, ER antagonistic ligands such as endoxifen and cyclofenil related compounds are chosen as the targeting mechanism for the conjugate, with the objective of designing effective antiproliferative compounds for in vitro evaluation. The introduction of steric hindrance provided by the combretastatin CA-4 amide fragment is now investigated to determine if this modification enhances the ER antagonistic effects of the endoxifen and cyclofenil conjugates in the ER positive MCF-7 cells, possibly by interference with Helix-12 of the ER. To determine the influence of ER ligand structural modifications of the conjugate on antiproliferative activity in ER positive MCF-7 breast cancer cells, the following ER ligand conjugate structural types will be investigated:

1. Endoxifen-combretastatin-related acrylic acid conjugates $\mathbf{3 a - 3 k}$

2. Endoxifen-combretastatin-related modified acrylic acid conjugates $\mathbf{5 a - 5 d}$

3. Cyclofenil-combretastatin-related acrylic acid conjugates 13a-13e

4. Endoxifen-combretastatin ester type conjugates 16a-16c

\section{Results and Discussion}

\subsection{Synthesis of Conjugates}

For this study the required combretastatin related acrylic acids 1a-1r (Table 1) were prepared using the Perkin condensation reaction which is an efficient synthetic route for novel combretastatin acrylic acid analogues from a variety of aldehyde and phenylacetic acid starting materials as shown in Scheme 1 [50]. The carboxylic acid located on the ethylene products will facilitate the conjugate formation with the ER ligands via coupling reactions to afford the required ester or amide linking system. Selection of the series of acrylic acids for synthesis was initially based on the requirement for the 3,4,5-trimethoxyphenyl substitution for ring A of CA4; however, other structurally related substitutions were also used as shown in Scheme 1. The panel of novel and previously reported acrylic acid combretastatin analogues $\mathbf{1 a}-\mathbf{1 r}$ were synthesised via the Perkin reaction using both the reflux and microwave methods [51]. In all cases studied the yields for the microwave method were superior to those of the conventional technique method with shorter reaction time (<30 $\mathrm{min}$ ) and with exclusive formation of the desired cis isomer. 2-(3,5-Dimethoxyphenyl)acetic acid and 2-(3-hydroxy-4-methoxyphenyl)acetic acid were prepared as described in the Supplementary information. Combretastatin CA-4 was used as a standard reference and was prepared by the Wittig reaction sequence [52] or by decarboxylation of $\mathbf{1 1}$ [50].

Endoxifen was chosen as a suitable ER-ligand scaffold due to its high affinity ER-binding properties. Additionally, the secondary amine group present on the basic side chain can undergo amide 
type coupling reactions to synthesise the prototype conjugated compounds. The OTBDMS protected endoxifen ligand $\mathbf{2 a}$ was prepared in a multistep route as we previously reported via the McMurry reaction which is a low valent titanium mediated crossed coupling of substituted benzophenones and ketones [31].

Table 1. Structures of acrylic acids 1a-1r (see Scheme 1).

\begin{tabular}{|c|c|c|c|c|c|c|c|c|}
\hline Compound & $\mathbf{R}_{1}$ & $\mathbf{R}_{2}$ & $\mathbf{R}_{3}$ & $\mathbf{R}_{4}$ & $\mathbf{R}_{5}$ & $\mathbf{R}_{6}$ & $\mathbf{R}_{7}$ & Yield (\%) \\
\hline $1 \mathrm{a}$ & $\mathrm{OMe}$ & $\mathrm{OMe}$ & $\mathrm{OMe}$ & $\mathrm{H}$ & $\mathrm{OMe}$ & $\mathrm{NO}_{2}$ & $\mathrm{H}$ & 63 \\
\hline $1 b$ & $\mathrm{OMe}$ & $\mathrm{H}$ & $\mathrm{OMe}$ & $\mathrm{OMe}$ & $\mathrm{OMe}$ & $\mathrm{OMe}$ & $\mathrm{H}$ & 35 \\
\hline $1 c$ & $\mathrm{OMe}$ & $\mathrm{OMe}$ & $\mathrm{OMe}$ & $\mathrm{OMe}$ & $\mathrm{OMe}$ & $\mathrm{OMe}$ & $\mathrm{H}$ & 96 \\
\hline 1d & $\mathrm{OMe}$ & $\mathrm{H}$ & $\mathrm{OMe}$ & $\mathrm{H}$ & $\mathrm{OMe}$ & $\mathrm{OH}$ & $\mathrm{H}$ & 7 \\
\hline 1e & $\mathrm{OMe}$ & $\mathrm{OMe}$ & $\mathrm{OMe}$ & $\mathrm{H}$ & $\mathrm{OH}$ & $\mathrm{OH}$ & $\mathrm{H}$ & 36 \\
\hline 1f & $\mathrm{OMe}$ & $\mathrm{OMe}$ & $\mathrm{OMe}$ & $\mathrm{H}$ & $\mathrm{H}$ & $\mathrm{OH}$ & $\mathrm{H}$ & 88 \\
\hline $1 \mathrm{~g}$ & $\mathrm{OMe}$ & $\mathrm{OMe}$ & $\mathrm{OMe}$ & $\mathrm{H}$ & $\mathrm{OMe}$ & $\mathrm{OMe}$ & $\mathrm{H}$ & 45 \\
\hline $1 \mathrm{~h}$ & $\mathrm{OMe}$ & $\mathrm{OMe}$ & $\mathrm{OMe}$ & $\mathrm{H}$ & $\mathrm{OMe}$ & $\mathrm{OMe}$ & $\mathrm{OMe}$ & 30 \\
\hline $1 \mathrm{i}$ & $\mathrm{H}$ & $\mathrm{OMe}$ & $\mathrm{OH}$ & $\mathrm{OMe}$ & $\mathrm{OMe}$ & $\mathrm{OMe}$ & $\mathrm{H}$ & 38 \\
\hline $\mathbf{1 j}$ & $\mathrm{OMe}$ & $\mathrm{OMe}$ & $\mathrm{OMe}$ & $\mathrm{OMe}$ & $\mathrm{OH}$ & $\mathrm{OMe}$ & $\mathrm{H}$ & 48 \\
\hline $1 \mathrm{k}$ & $\mathrm{H}$ & $\mathrm{OMe}$ & $\mathrm{H}$ & $\mathrm{H}$ & $\mathrm{OCOCH}_{3}$ & $\mathrm{H}$ & $\mathrm{H}$ & 56 \\
\hline 11 & $\mathrm{OMe}$ & $\mathrm{OMe}$ & $\mathrm{OMe}$ & $\mathrm{H}$ & $\mathrm{OMe}$ & $\mathrm{OH}$ & $\mathrm{H}$ & 36 \\
\hline $1 \mathrm{~m}$ & $\mathrm{H}$ & $\mathrm{OMe}$ & $\mathrm{H}$ & $\mathrm{H}$ & $\mathrm{OCH}_{2} \mathrm{O}$ & & $\mathrm{H}$ & 49 \\
\hline 1n & $\mathrm{OMe}$ & $\mathrm{OMe}$ & $\mathrm{OMe}$ & $\mathrm{H}$ & $\mathrm{OMe}$ & $\mathrm{H}$ & $\mathrm{H}$ & 71 \\
\hline 10 & $\mathrm{H}$ & OMe & $\mathrm{H}$ & $\mathrm{OMe}$ & $\mathrm{OMe}$ & $\mathrm{OMe}$ & $\mathrm{H}$ & 47 \\
\hline $1 p$ & $\mathrm{OMe}$ & $\mathrm{OMe}$ & $\mathrm{OMe}$ & - & 2-Methylthienyl & - & - & 45 \\
\hline $1 \mathrm{q}$ & $\mathrm{OMe}$ & $\mathrm{OMe}$ & $\mathrm{OMe}$ & - & 3-Furfuryl & - & - & 64 \\
\hline $1 \mathrm{r}$ & $\mathrm{OMe}$ & $\mathrm{OMe}$ & $\mathrm{OMe}$ & $\mathrm{H}$ & $\mathrm{OMe}$ & $\mathrm{OH}$ & $\mathrm{H}$ & 83 \\
\hline
\end{tabular}<smiles>[R]c1cc(CC(=O)O)cc([R])c1[R2]</smiles><smiles>[R]Cc1cc(C=O)c([R6])c([R6])c1[R6]</smiles><smiles>C#CCCCC</smiles><smiles>[R]c1cc(/C(=C/c2cc([R3])c([R5])c([R6])c2[R])C(=O)O)cc([R])c1[R2]</smiles>

$1 \mathrm{a}-1 \mathrm{r}$

Scheme 1. Synthesis of acrylic acids 1a-1r: Reagents and conditions: (i) $\left(\mathrm{CH}_{3} \mathrm{CO}\right)_{2} \mathrm{O}, \mathrm{Et}_{3} \mathrm{~N}$, microwaves, $100^{\circ} \mathrm{C}, 0.5 \mathrm{~h}$, followed by conc $\mathrm{HCl}$.

The McMurry reaction has been the route of choice for the preparation of the triarylethylene scaffold as it commonly leads to favourable $E: Z$ isomer ratios. [53] The $E: Z$ isomeric ratio for $2 \mathbf{a}$ is calculated as 1:1.3 based on the integral of the signals of the chemical shifts assigned to the $\mathrm{OCH}_{2}$ and $\mathrm{NCH}_{2}$ signals for the protons of the basic side chain in the isomeric mixtures [54]. However, 4-hydroxytamoxifen and endoxifen and related 4-hydroxysubstituted triarylethylenes undergo $E / Z$ isomerisation under physiological conditions, and have little effect on ER activity [55-57]. Therefore, the $E / Z$ isomer mixture of $\mathbf{2 a}$ obtained in the present work was used without further separation in the formation of the subsequent conjugates. Deprotection of $2 \mathbf{a}$ affords endoxifen.

The acrylic acid combretastatin analogues $\mathbf{1 a}-\mathbf{1 j}, \mathbf{1 m}, \mathbf{1} \mathbf{p}, \mathbf{1 q}$ were directly coupled to the silyl-protected endoxifen analogue $\mathbf{2 a}$ to afford the conjugates 3a-3m (Scheme 2, Table 2). The initial coupling procedure investigated DCC as the coupling agent for the synthesis of this series of conjugates. Equimolar amounts of the acrylic acid, amine $2 \mathrm{a}$ DCC and HOBt were reacted and the reaction was monitored via TLC. The resulting silyl-protected conjugates were treated with TBAF to afford the direct amide conjugates $3 \mathbf{a}-\mathbf{3 m}$ in high yields as $~ 1: 1$ (E/Z)-isomeric mixtures, Table 2 . The isomeric ratios were calculated based on those of the endoxifen starting material and confirmed by integration of appropriate signals in the ${ }^{1} \mathrm{H}-\mathrm{NMR}$ spectra. The presence of rotamers also resulted in complex 
spectra. EDC was also used as the coupling reagent for the synthesis of conjugates $3 \mathbf{a}-\mathbf{3 k}$. The related amide compounds $\mathbf{3 n}, \mathbf{3 o}, \mathbf{3 p}$ and $\mathbf{3 q}$ were prepared for biochemical evaluation by reaction of the acrylic acids $\mathbf{1 1}, \mathbf{1 n}$ and $\mathbf{1 p}$ with ammonium acetate and diethylamine respectively (Scheme 3 ).

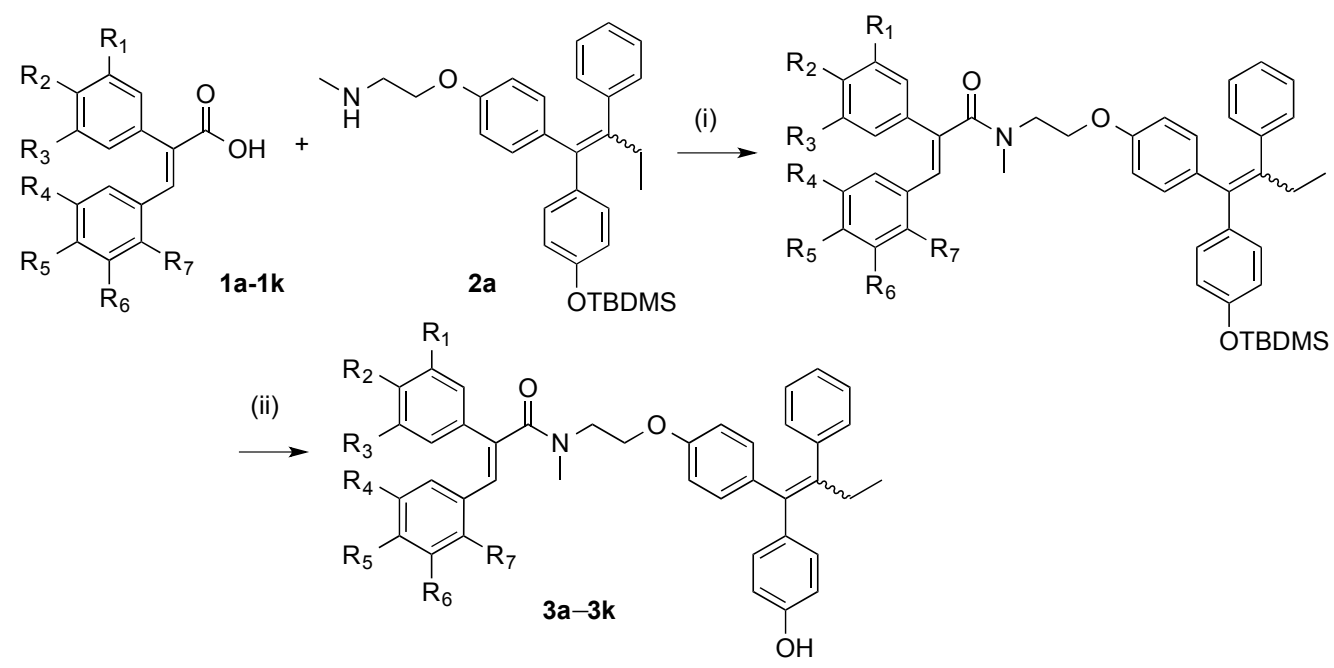<smiles>CCC(=C(c1ccccc1)c1ccc(OCCN(C)C(=O)c2cc(OC)c(OC)c(OC)c2)cc1)c1cc(OC)c(OC)c(OC)c1</smiles>

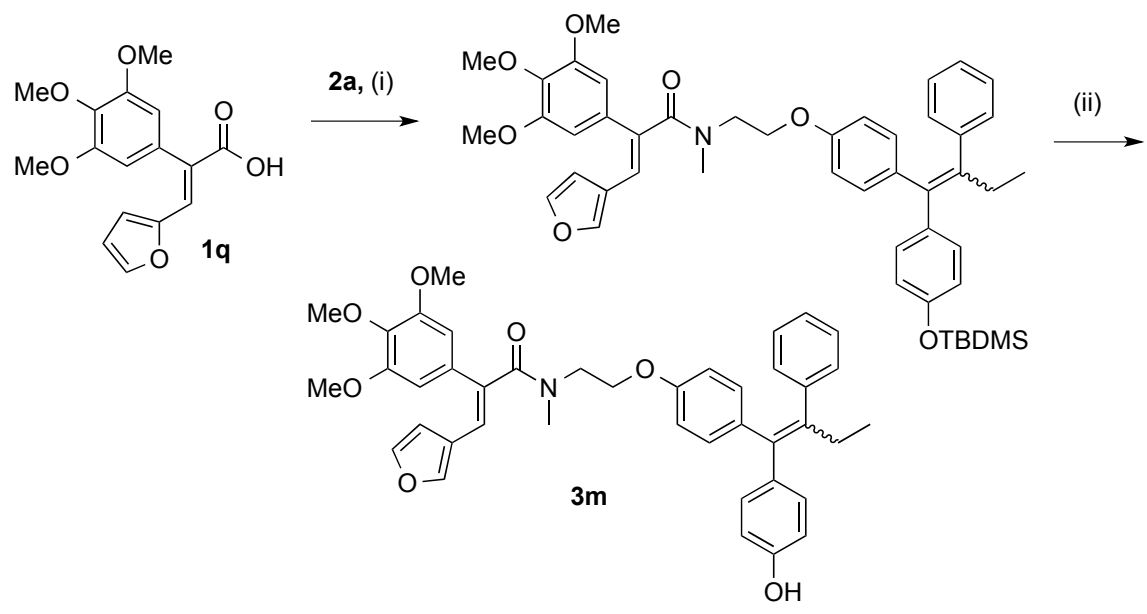

Scheme 2. Synthesis of combretastatin-endoxifen conjugates $3 \mathrm{a}-3 \mathrm{~m}$. Reagents and Conditions: ${ }^{\mathrm{a}}$ (i) DCC, $\mathrm{HOBt}, \mathrm{CH}_{2} \mathrm{Cl}_{2}, 24 \mathrm{~h}, 20^{\circ} \mathrm{C}$; (ii)TBAF, THF, $0.5 \mathrm{~h}, 20{ }^{\circ} \mathrm{C}$; ${ }^{\mathrm{b}}$ (i) EDC, $\mathrm{HOBt}, \mathrm{CH}_{2} \mathrm{Cl}_{2}, 24 \mathrm{~h}, 20{ }^{\circ} \mathrm{C}$; (ii) TBAF, THF, $0.5 \mathrm{~h}, 20^{\circ} \mathrm{C}$. 
Table 2. Conjugate compounds 3a-3k.<smiles>[R]c1cc(/C(=C\c2cc([R4])c([R5])c([R6])c2[R7])C(=O)N(C)CCOc2ccc(C(=C(CC)c3ccccc3)c3ccc(O)cc3)cc2)cc([R1])c1[R]</smiles>

\begin{tabular}{|c|c|c|c|c|c|c|c|c|}
\hline Compound & $\mathbf{R}_{1}$ & $\mathbf{R}_{2}$ & $\mathbf{R}_{3}$ & $\mathbf{R}_{4}$ & $\mathbf{R}_{5}$ & $\mathbf{R}_{6}$ & $\mathbf{R}_{7}$ & Yield * \\
\hline $3 \mathbf{a}$ & $\mathrm{OMe}$ & $\mathrm{OMe}$ & $\mathrm{OMe}$ & $\mathrm{H}$ & $\mathrm{OMe}$ & $\mathrm{NO}_{2}$ & $\mathrm{H}$ & $82^{b}$ \\
\hline $3 b$ & $\mathrm{OMe}$ & $\mathrm{H}$ & $\mathrm{OMe}$ & $\mathrm{OMe}$ & $\mathrm{OMe}$ & $\mathrm{OMe}$ & $\mathrm{H}$ & $33^{\mathrm{a}}$ \\
\hline $3 c$ & $\mathrm{OMe}$ & $\mathrm{OMe}$ & $\mathrm{OMe}$ & $\mathrm{OMe}$ & $\mathrm{OMe}$ & $\mathrm{OMe}$ & $\mathrm{H}$ & $83^{b}$ \\
\hline $3 d$ & $\mathrm{OMe}$ & $\mathrm{H}$ & $\mathrm{OMe}$ & $\mathrm{H}$ & $\mathrm{OMe}$ & $\mathrm{OH}$ & $\mathrm{H}$ & $54^{\mathrm{a}}$ \\
\hline $3 e$ & $\mathrm{OMe}$ & $\mathrm{OMe}$ & $\mathrm{OMe}$ & $\mathrm{H}$ & $\mathrm{OH}$ & $\mathrm{OH}$ & $\mathrm{H}$ & $60^{b}$ \\
\hline $3 \mathrm{f}$ & $\mathrm{OMe}$ & $\mathrm{OMe}$ & $\mathrm{OMe}$ & $\mathrm{H}$ & $\mathrm{H}$ & $\mathrm{OH}$ & $\mathrm{H}$ & $45^{\mathrm{a}}$ \\
\hline $3 g$ & $\mathrm{OMe}$ & $\mathrm{OMe}$ & $\mathrm{OMe}$ & $\mathrm{H}$ & $\mathrm{OMe}$ & $\mathrm{OMe}$ & $\mathrm{H}$ & $79^{b}$ \\
\hline $3 h$ & $\mathrm{OMe}$ & $\mathrm{OMe}$ & $\mathrm{OMe}$ & $\mathrm{H}$ & $\mathrm{OMe}$ & $\mathrm{OMe}$ & $\mathrm{OMe}$ & $26^{\mathrm{a}}$ \\
\hline $3 \mathbf{i}$ & $\mathrm{H}$ & $\mathrm{OMe}$ & $\mathrm{OH}$ & $\mathrm{OMe}$ & $\mathrm{OMe}$ & $\mathrm{OMe}$ & $\mathrm{H}$ & $77^{b}$ \\
\hline $3 \mathbf{j}$ & $\mathrm{OMe}$ & $\mathrm{OMe}$ & $\mathrm{OMe}$ & $\mathrm{OMe}$ & $\mathrm{OH}$ & $\mathrm{OMe}$ & $\mathrm{H}$ & $71^{b}$ \\
\hline $3 k$ & $\mathrm{H}$ & $\mathrm{OMe}$ & $\mathrm{H}$ & $\mathrm{H}$ & \multicolumn{2}{|c|}{$\mathrm{OCH}_{2} \mathrm{O}$} & $\mathrm{H}$ & $45^{b}$ \\
\hline 31 & $\mathrm{OMe}$ & $\mathrm{OMe}$ & $\mathrm{OMe}$ & 2-Methylthienyl & - & - & - & $16^{\mathrm{b}}$ \\
\hline $3 m$ & $\mathrm{OMe}$ & $\mathrm{OMe}$ & $\mathrm{OMe}$ & 3-Furfuryl & - & - & - & $76^{\mathrm{b}}$ \\
\hline
\end{tabular}

* Overall yield: coupling and deprotection. ${ }^{\mathrm{a}}$ (i) DCC, $\mathrm{HOBt}, \mathrm{CH}_{2} \mathrm{Cl}_{2}, 24 \mathrm{~h}, 20^{\circ} \mathrm{C}$; (ii)TBAF, THF, $0.5 \mathrm{~h}, 2{ }^{\circ} \mathrm{C}$; ${ }^{\mathrm{b}}$ (i) EDC, HOBt, $\mathrm{CH}_{2} \mathrm{Cl}_{2}, 24 \mathrm{~h}, 20^{\circ} \mathrm{C}$; (ii) TBAF, THF, $0.5 \mathrm{~h}, 20^{\circ} \mathrm{C}$.<smiles>[R]c1cc(/C=C(/C(=O)O)c2cc([R4])c(OC)c([R])c2)cc([R4])c1OC</smiles>

10 $\mathrm{R}_{1}=\mathrm{R}_{2}=\mathrm{H}, \mathrm{R}_{3}=\mathrm{R}_{4}=\mathrm{OCH}_{3}$ 1I $\mathrm{R}_{1}=\mathrm{R}_{2}=\mathrm{OCH}_{3}, \mathrm{R}_{3}=\mathrm{OH}, \mathrm{R}_{4}=\mathrm{H}$ 1n $\mathrm{R}_{1}=\mathrm{R}_{2}=\mathrm{OCH}_{3}, \mathrm{R}_{3}=\mathrm{R}_{4}=\mathrm{H}$ (i), (ii) or (iii)<smiles>[R5]NC(=O)C(=NS[R5])C(=O)/C(=C/c1cc([R3])c(OC)c([R4])c1)c1cc([R])c(OC)c([R])c1</smiles>

Scheme 3. Synthesis of combretastatin-amides 3n-3q: Reagents and conditions: 3o, 3q (i) Mukaiyama's reagent, $\mathrm{Et}_{3} \mathrm{~N}, \mathrm{DCM}, 3 \mathrm{~h}, 20^{\circ} \mathrm{C}$; 3 n (ii) $(\mathrm{COCl})_{2}, \mathrm{DMF}, \mathrm{DCM}, 12 \mathrm{~h}, 20{ }^{\circ} \mathrm{C}$, followed by $\mathrm{NH}_{4} \mathrm{OH}$; $3 \mathbf{p}$ (iii) $\mathrm{SOCl}_{2}, \mathrm{DCM}, \mathrm{Et}_{3} \mathrm{~N}, 2 \mathrm{~h}$ followed by $\mathrm{NH}_{4} \mathrm{OH}, 12 \mathrm{~h}, 20^{\circ} \mathrm{C}$.

A further objective of this project was to prepare conjugates of endoxifen with cinnamic and phenylpropanoic acids related in structure to A and B rings of CA4. For this modified structure the substituent ring would now be either the 3,4,5-trimethoxy ring (A ring) or the 3-hydroxy-4-methoxy-ring ( $\mathrm{B}$ ring). Both rings ( $\mathrm{A}$ and $\mathrm{B}$ ) have been shown to be relevant for the antitubulin CA4 activity [45]. The cinnamic acids $\mathbf{4 a}$ and $\mathbf{4} \mathbf{c}$ were prepared by reaction of the appropriate aryl aldehyde with malonic acid under microwave conditions [58]; subsequent reduction via a palladium/C hydrogenation afforded the 3-phenylpropanoic acids $\mathbf{4 b}$ and $\mathbf{4 d}$ [59] with yields 
in excess of $80 \%$. (See Supplementary information). The compounds $\mathbf{4 a - 4 d}$ were then used to synthesise the required endoxifen conjugates 5a-5d via EDC or DCC and HOBt coupling reactions; the intermediate silyl-protected conjugates were deprotected with TBAF affording the desired amide conjugates in high yields (90-95\%) as 1:1 (E/Z)-isomeric mixtures, (Scheme 4).

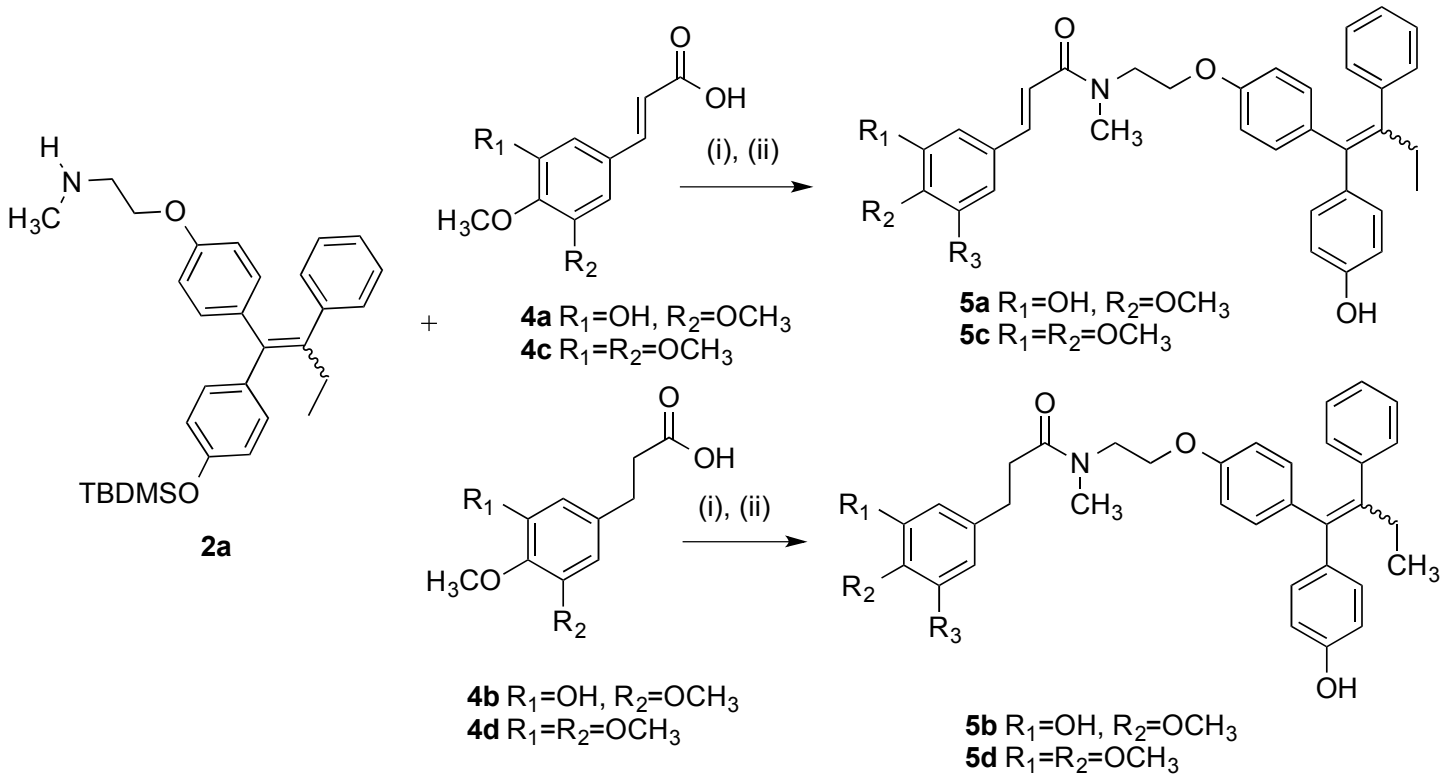

Scheme 4. Synthesis of cinnamic and propanoic acid-combretastatin hybrid conjugates $\mathbf{5 a}-\mathbf{5 d}$. Reagents and conditions: (i) DCC or EDC, HOBt, $\mathrm{CH}_{2} \mathrm{Cl}_{2}, 24 \mathrm{~h}, 20^{\circ} \mathrm{C}$; (ii) TBAF, THF, $0.5-24 \mathrm{~h}, 20^{\circ} \mathrm{C}$.

In the present study, the cyclofenil analogues chosen for synthesis retain the cycloalkyl group of the cyclofenil parent structure, while in addition, they include the basic side chain moiety of the endoxifen parent structure. Unlike the previous synthesis of the triarylethylene scaffold for the endoxifen analogues, the use of a cyclic ketone eliminates any issue of $E$ - and $Z$ - isomers in the products. It was envisioned that the elimination of the $E / Z$ isomers could lead to a simpler purification step and would result in a less complex NMR spectra.

The 4,4'-dihydroxybenzophenone 6 (protected as the OTBDMS ether 7) was reacted with the appropriate cyclic ketone (cyclopentanone, cyclohexanone, cycloheptanone, cyclooctanone and 4-methylcyclohexanone) under the McMurry reaction conditions to give the compounds $\mathbf{8 a}-\mathbf{8} \mathbf{e}$ respectively, (Scheme 5).

Compounds 8a-8e then underwent an ethylbromination reaction to afford 9a-9e. Following an amination reaction step, analogues 10a-10e were used in the formation of novel conjugates. Compounds 10a-10e were subsequently deprotected to afford the endoxifen-type cyclofenil analogues 11a-11e. These novel ER ligands containing a basic side chain ether similar to that of endoxifen, were subsequently used for the novel linkage to the CA4-type cytotoxic agent. The acrylic acid combretastatin analogue $\mathbf{1 1}$ was directly coupled to the silyl-protected cyclofenil-based analogues 10a-10e to afford the protected conjugates 12a-12e. This procedure employed EDC as the coupling reagent. The synthesis of this series of silyl-protected conjugates was similar to that for the endoxifen conjugates synthesis $3 \mathbf{a}-\mathbf{3 k}$ the reagent ratio was optimised: 1.2 eq. of acrylic acid, 1.4 eq. DCC, 1.4 eq. $\mathrm{HOBt}$ and 1 eq of amine were reacted and the reaction was monitored via TLC. The silyl-protected conjugates 12a-12e were isolated and fully characterised and then treated with TBAF to afford the direct amide conjugates 13a-13e in high yields (Scheme 5). 


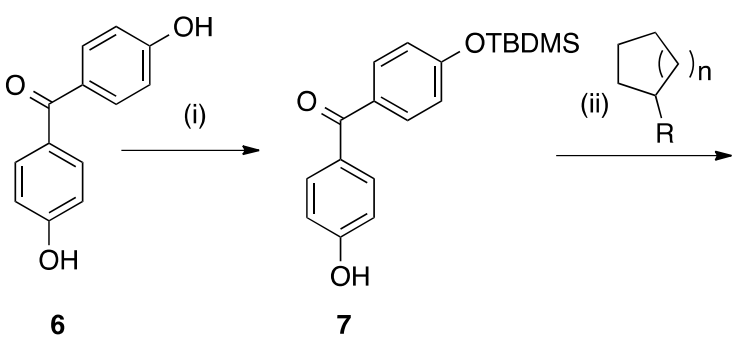<smiles></smiles><smiles>[R]C1CCC(=C(c2ccc(OCCNC)cc2)c2ccc(OCCNC)cc2)C1=C(c1ccc(OCCNC)cc1)c1ccc(OCCNC)cc1</smiles><smiles>COc1ccc(/C=C(\C(=O)O)c2cc(OC)c(OC)c(OC)c2)cc1O</smiles>

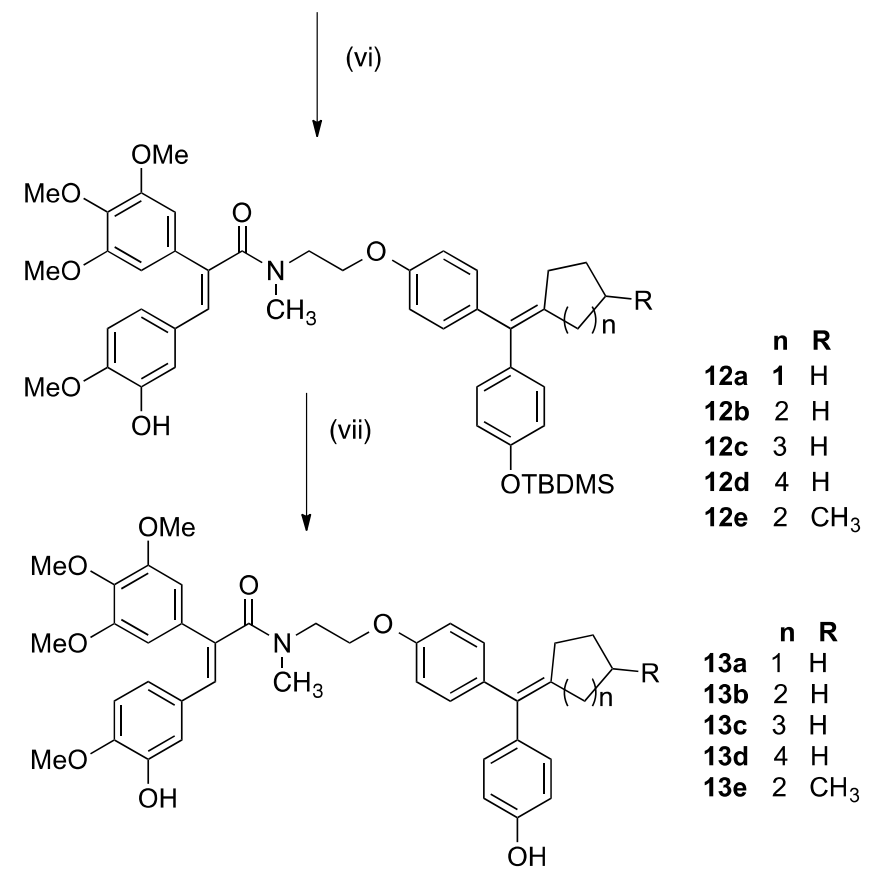

Scheme 5. Synthesis of cyclofenil-combretastatin hybrid conjugates 13a-13e. Reagents and conditions: (i) TBDMSCl, imidazole, DMF; (ii) $\mathrm{Zn}, \mathrm{TiCl}_{4}$; (iii) $\left.\mathrm{Br}_{2}\left(\mathrm{CH}_{2}\right)_{2}, \mathrm{NaOH}(\mathrm{aq}), \mathrm{nBu}\right) 4 \mathrm{NHSO}_{3}, \mathrm{CH}_{2} \mathrm{Cl}_{2}$; (iv) $\mathrm{CH}_{3} \mathrm{NH}_{2}$, sealed tube, $60{ }^{\circ} \mathrm{C}$; (v) TBAF, THF; (vi) EDC, $\mathrm{HOBt}, \mathrm{CH}_{2} \mathrm{Cl}_{2}, 24 \mathrm{~h}, 0^{\circ} \mathrm{C}$; (vii) TBAF, THF, $0.5 \mathrm{~h}, 0^{\circ} \mathrm{C}$.

With all of the conjugate prototypes investigated to date, the synthesis of the conjugates required a coupling reaction between a carboxylic acid group with an amine forming an amide linkage. Coupling of the phenolic functionality of CA-4 with the free carboxylic acid group of diacid linker compounds, forming ester linkages was also investigated. A diacid type linker was chosen to allow for the formation of ester and/or amide bonds with any available phenol and/or amine groups present on the conjugate component-fragments. Therefore, it is envisioned that these diacid fragments can be metabolised easily in vivo thus releasing the conjugate component ligands and possibly exerting a dual action effect. 
Desmethyltamoxifen $\mathbf{2 b}$ was initially used as the prototype ER-ligand for the DCC coupling reaction with the dicarboxylic acid (Scheme 6). Succinic acid, DCC and HOBt were reacted with $\mathbf{2 b}$ and an isomeric mixture ( $E: Z=1: 2.3)$ of the product 14a was afforded (90\% yield) (see Scheme 6). It was found that the reactions involving the formation of the diacid linker compounds from secondary amine, triarylethylenes with acid anhydrides were successful without the need for any additional reagents such as DCC, HOBt or DMAP. Succinic anhydride was reacted successfully with desmethyltamoxifen $\mathbf{2 b}$ to afford the diacid-linker compounds 14a in 97\% yield.

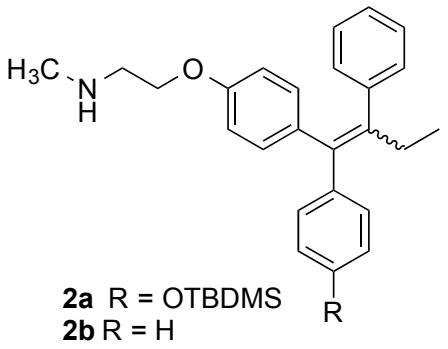<smiles>O=C(O)CCC(=O)O</smiles>

(i)

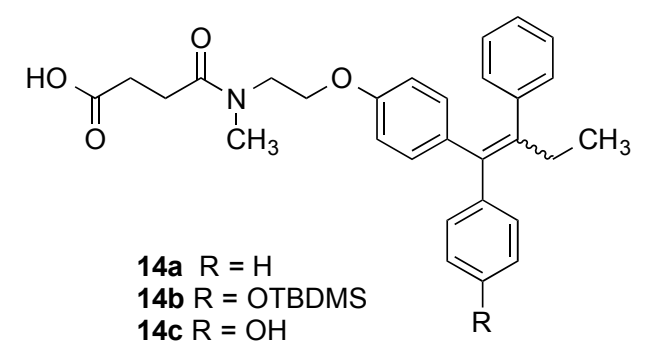<smiles>COc1ccc(-c2ccc(OC)c(OC)c2)cc1O</smiles>

(i), (ii)<smiles>[R]c1ccc(C(=C(CC)c2ccccc2)c2ccc(OCCN(C)C(=O)CCC(=O)Oc3cc(/C=C\c4cc(OC)c(OC)c(OC)c4)ccc3OC)cc2)cc1</smiles><smiles>CCC(=C(c1ccccc1)c1ccccc1)c1ccc(OCCN(C)C(=O)CCC(=O)O)cc1</smiles><smiles>COC(=O)/C(=C/c1ccc(OC)c(O)c1)c1cc(OC)c(OC)c(OC)c1</smiles><smiles>CCC(=C(c1ccccc1)c1ccc(OCCN(C)C(=O)CCC(=O)Oc2cc(C=C(C(=O)OC)c3cc(OC)c(OC)c(OC)c3)ccc2OC)cc1)c1ccccc1</smiles>

Scheme 6. Synthesis of endoxifen-combretastatin conjugates 16a-16c. Reagents and Conditions: (i) DCC, DMAP, DCM; (ii) (a) DCC, DMAP, DCM (b) TBAF, THF. 
In addition to the preliminary diacid reactions carried out on desmethyltamoxifen $\mathbf{2} \mathbf{b}$, succinic anhydride was next reacted with the silyl-protected endoxifen analogue $\mathbf{2 a}$ to afford $\mathbf{1 4 b}$. The phenol group present on the endoxifen ligand plays an important role in ER-binding and is a desirable functionality on the proposed conjugate structures for improved ER-binding and overall bioactivity. Initially, it was decided to carry out the conjugate prototype reactions using a single linker-ligand $\mathbf{1 4 b .}$ The succinic linker was chosen as it is a flexible fragment and allows the conjugate some flexibility. Therefore, the prototype succinic-conjugates would not be overly restricted and adopt a configuration for optimal binding.

The use of DCC with HOBt was effective for the majority of the coupling reactions above; however coupling of CA-4 15 with the diacid linker compound 14a to afford the conjugate 16a gave very low yields (Scheme 5). It was then decided to first react the diacid linker component succinic acid with the CA4 structure and then to react the resulting CA4-linker product with the desmethyltamoxifen analogue $\mathbf{2 b}$ forming the amide linkage of the conjugate 16a. However, initial attempts to couple the succinic acid/anhydride linker directly to CA4 were unsuccessful using a variety of reaction conditions (e.g., DCC/HOBt, $\mathrm{Et}_{3} \mathrm{~N}$, or Mitsunobu conditions, $\mathrm{PPh}_{3} / \mathrm{DIAD}$ ). Pettit et al. reported the synthesis of succinic acid esters of combretastatin analogues as CA4 prodrugs and water soluble derivatives [41]. In the present study CA4 15 was treated with 14b using DCC coupling conditions with DMAP as a base. The coupling reaction was successful (Scheme 5) and the intermediate protected conjugate was treated with TBAF to give the target compound $\mathbf{1 6 b}$ as an isomeric mixture $(E: Z=1: 1)$ in a high yield $(88 \%)$. Similarly, 16a was obtained in high yield (83\%) by reaction of 15 with the desmethyltamoxifen $\mathbf{2 b}$. The related conjugate $\mathbf{1 6 c}$ was prepared by coupling of the acrylic acid 14a with the phenolic ester 1s, to afford a product with additional ester functionality on the acrylic alkene (Scheme 6).

The stability of the target conjugate compounds 16a, 16b and 16c, was evaluated in phosphate buffer at $\mathrm{pH}$ values in the range 4-9 also in plasma and the half-life was determined to be greater than $20 \mathrm{~h}$ for each compound at these $\mathrm{pH}$ values. For the most potent conjugate compound $16 \mathrm{~b},>90 \%$ remained over $\mathrm{pH}$ range $4-9$ at $12 \mathrm{~h}$ with half life $>48 \mathrm{~h}$; and $77 \%$ remained intact in plasma at $12 \mathrm{~h}$, with a half life $>48 \mathrm{~h}$. We observed no significant degradation of the conjugate. This result indicates that the combretastatin stilbene moiety of the endoxifen conjugate structure is required for optimum interaction with helix 12 of the ER LBD, and contributes to the observed ER antagonistic effects.

\subsection{Antiproliferative Activity in MCF-7 Breast Cancer Cells}

The antiproliferative activity of the conjugate compounds synthesised was first evaluated using the ER-expressing (ER-dependent) MCF-7 human breast cancer cell line. Alamar Blue dye was used to quantify the cell viability. Cytotoxicity in MCF-7 cells was determined using the LDH assay [60]. Tamoxifen $\left(\mathrm{IC}_{50} 2.13 \mu \mathrm{M}\right)$, endoxifen $\left(\mathrm{IC}_{50} 0.029 \mu \mathrm{M}\right)$, and $\mathrm{CA}-4\left(\mathrm{IC}_{50} 3.57 \mathrm{nM}\right)$ were used as postive control compounds in the MCF-7 human breast cancer cell line. The $\mathrm{IC}_{50}$ values obtained are in agreement with the previously reported antiproliferative activity for these compounds which are: for $\mathrm{CA}-4, \mathrm{IC}_{50}=0.008 \mu \mathrm{M}$ [61-63]; tamoxifen $\mathrm{IC}_{50}=4.4 \mu \mathrm{M}$ [64], endoxifen $\mathrm{IC}_{50}=50 \mathrm{nM}$ [65] in the MCF-7 human breast cancer cell line.

The conjugate compounds synthesised incorporating the ER-binding triphenylethylene moiety of the SERM endoxifen 3a-3k were initially evaluated for their ability to reduce the viability of the MCF-7 cell line. In the present study, the terminal methylamine basic substituent was designed to mimic the endoxifen basic side chain structure. It was hypothesised that by incorporating a basic side chain linker of the endoxifen structure onto the combretastatin acrylic acid moiety that high affinity ER ligands with potential antagonist activity may be achieved. A range of novel substituted acrylic acids were evaluated in the MCF-7 cell line. The biochemical data observed is presented in Table 2. The most active of the series of conjugate compounds $\mathbf{3 i}$ and $\mathbf{3 k}$ demonstrated micromolar $\mathrm{IC}_{50}$ activity (Table 3) with $\mathrm{IC}_{50}$ value of $4.2 \mu \mathrm{M}$ and $1.47 \mu \mathrm{M}$ respectively. The lead compound 3i which incorporated the 3,4,5-trimethoxyphenyl Ring A and 3-hydroxy4-methoxyphenyl Ring $\mathrm{B}$ of CA4 in the structure of the acrylic acid moiety remains the key compound from this series. 
We had previously demonstrated the activity of the reverse CA4 conjugate [31]. The diversly substituted acrylic acid analogues were further investigated to enhance the activity seen for $3 \mathbf{i}$. Compound $\mathbf{3 j}$ containing the 3,5-dimethoxy-4-hydroxy substitution pattern (Ring B of the acrylic acid) displayed weak antiproliferative activity $\left(\mathrm{IC}_{50}=11.8 \mu \mathrm{M}\right)$, as did the furan containing compound $3 \mathrm{~m}\left(\mathrm{IC}_{50}=36.5 \mu \mathrm{M}\right)$.

Table 3. Antiproliferative effects of acrylic acid conjugates in MCF-7 human breast cancer cells a

\begin{tabular}{|c|c|c|c|c|c|}
\hline Compound & $\mathrm{IC}_{50}(\mu \mathrm{M})^{\mathrm{b}}$ & $\operatorname{cLog} P \mathrm{j}$ & Compound & $\mathrm{IC}_{50}(\mu \mathrm{M})^{\mathrm{b}}$ & $\mathrm{cLog} P \mathrm{j}$ \\
\hline $3 a$ & $>50$ & 8.19 & $11 a$ & 3.09 & 4.62 \\
\hline $3 b$ & $>50$ & 8.02 & $11 b$ & 4.78 & 5.18 \\
\hline $3 c$ & $>50$ & 7.61 & 11c & 1.38 & 5.74 \\
\hline $3 d$ & $>50$ & 8.40 & $11 d$ & 3.23 & 6.30 \\
\hline $3 e$ & $>50$ & 7.42 & 11e & 1.77 & 5.70 \\
\hline $3 f$ & $>50$ & 7.84 & $5 a$ & 51.3 & 7.04 \\
\hline $3 g$ & $>50$ & 7.62 & $5 b$ & 46.77 & 6.82 \\
\hline $3 h$ & $>50$ & 7.63 & $5 c$ & $>50$ & 7.16 \\
\hline $3 \mathbf{i}$ & 4.20 & 7.69 & $5 d$ & $>50$ & 6.94 \\
\hline $3 \mathbf{j}$ & 11.75 & 9.09 & $13 a$ & 1.38 & 6.75 \\
\hline $3 \mathbf{k}$ & 1.47 & 7.33 & $13 b$ & 2.01 & 7.31 \\
\hline 31 & $>50$ & 8.65 & $13 c$ & 2.50 & 7.87 \\
\hline $3 m$ & 36.5 & 7.68 & $13 d$ & 0.346 & 7.83 \\
\hline $3 n$ & $\mathrm{f}$ & 2.15 & $13 e$ & 0.182 & 7.83 \\
\hline 30 & $\mathrm{~g}$ & 1.75 & $16 a$ & 0.090 & 8.73 \\
\hline $3 p$ & $\mathrm{~h}$ & 2.15 & $16 b$ & 0.0057 & 9.21 \\
\hline \multirow[t]{4}{*}{$3 q$} & $\mathrm{i}$ & 3.33 & $14 a$ & $>50$ & 5.28 \\
\hline & & & Tamoxifen $\mathrm{e}^{\mathrm{e}}$ & 2.13 & 6.82 \\
\hline & & & Endoxifen ${ }^{\mathrm{d}}$ & 0.029 & 6.04 \\
\hline & & & $\mathrm{CA} 4^{\mathrm{c}}$ & 0.008 & 3.32 \\
\hline
\end{tabular}

\footnotetext{
${ }^{a}$ Mean $\mathrm{IC}_{50}$ values of compounds for their antiproliferative effects and percent cytotoxicity on a human MCF-7 breast cancer cell line. ${ }^{\mathrm{b}} \mathrm{IC}_{50}$ values are half maximal inhibitory concentrations required to block the growth stimulation of MCF-7 cells. Values are an average of at least three experiments performed in triplicate with typical standard errors below $15 \%$. ${ }^{\text {c }}$ The $\mathrm{IC}_{50}$ value obtained for $\mathbf{1 4}$ (CA4) in this assay is $8 \mathrm{nM}$ for MCF-7 and is in good agreement with the reported values for CA4 in MCF-7 cell line [61-63]. ${ }^{d}$ The reported $\mathrm{IC}_{50}$ value for endoxifen in the MCF-7 cell line is $50 \mathrm{nM}$ [65]. ${ }^{e}$ The $\mathrm{IC}_{50}$ value for Tamoxifen is in agreement with the reported $\mathrm{IC}_{50}$ value in MCF-7 cells $(4.4 \mu \mathrm{M})$ [64]. ${ }^{\mathrm{f}} 20 \%$ growth inhibition for compound $3 \mathrm{n}$ at $1 \mu \mathrm{M} .{ }^{\mathrm{g}} 16 \%$ growth inhibition for compound 3 o at $1 \mu \mathrm{M}$. ${ }^{\mathrm{h}} 60 \%$ growth inhibition for compound $3 \mathrm{p}$ at $1 \mu \mathrm{M} .{ }^{\mathrm{i}} 25 \%$ growth inhibition for compound $3 \mathrm{q}$ at $1 \mu \mathrm{M}$. $\mathrm{j}$ cLogP values calculated from ChemDraw Ultra, version 12.0. (PerkinElmer, Waltham, MA, USA).
}

However, the majority of compounds $\mathbf{3 a}-\mathbf{3 m}$ investigated did not exhibit any antiproliferative activity below $\mathrm{IC}_{50}$ of $50 \mu \mathrm{M}$. Therefore, this indicates that the substituent on the acrylic acid analogues play a key role in determining the effects of these conjugates on cell proliferation. Compounds $3 \mathbf{a}-3 \mathrm{~m}$ all have cLogP values greater than 5 and are predicted to have poor oral absorption. The amides $\mathbf{3 n}-\mathbf{3 q}$ demonstrated low potency when evaluated against the MCF-7 cell line. Compounds 5a-5d were next investigated to determine the effect of the core structure of the conjugate scaffold on the antiproliferative activity. It was decided to determine if both aryl rings (A and B) of the combretastatin structure were required for optimum antiproliferative activity containing cinnamic acids and 3-phenylpropanoic acids which were subsequently coupled to form the desired conjugates $\mathbf{5 a} \mathbf{a} \mathbf{5 d}$. The biochemical data for compounds $\mathbf{5 a - 5 d}$ is presented in Table 3 . The four compounds evaluated for this investigation showed reduced activity compared with $\mathbf{3 i}$ and $\mathbf{3 k}$. Compounds $\mathbf{5 a}$ and $\mathbf{5} \mathbf{b}$ which have the $p$-methoxy and 3-OH substituent (Ring B CA4) showed weak activity, with $\mathrm{IC}_{50}$ values of 51.3 and $46.7 \mu \mathrm{M}$ respectively. Compounds $5 \mathbf{c}$ and $\mathbf{5 d}$ which contain the 3,4,5-trimethoxy substituent (Ring A) did not show any antiproliferative activity below $100 \mu \mathrm{M}$. Therefore from the biochemical data for this series it is apparent that the two aryl rings, A and B, of the combretastatin structure with the CA4 type substituents were essential for optimum antiproliferative activity of the conjugate compounds. 
The cyclofenil-based analogues 11a-11e were synthesised based on the reported cyclofenil structure which demonstrated impressive ER $\alpha$ and ER $\beta$ binding affinities. It was hypothesised that by incorporating a basic side chain onto the cyclofenil structures that high affinity ER ligands with potential antagonist activity may be achieved. The cyclofenil-based analogues were designed to be used as the potential ER targeting ligands for this series of conjugates. As these cyclofenil-based analogues were novel compounds it was decided that they should be first evaluated individually for antiproliferative activity. This data would be beneficial as it would allow the cyclofenil conjugates 13a-13e to be compared directly to ER-ligands 11a-11e for reduced/enhanced activity.

The biochemical data for compounds 11a-11e is presented in Table 3. The cyclofenil-based analogues 11a-11e all showed low micromolar antiproliferative activity in MCF-7 cells with $\mathrm{IC}_{50}$ values ranging from 1.38 to $4.78 \mu \mathrm{M}$. This activity allowed for the rationalization of the next series of conjugates that incorporated the cyclofenil-based analogues. In this series only 11a had a CLogP less than 5 , and this compound would be expected to demonstrate reasonable oral absorption properties. The conjugates 13a-13e incorporated the novel ER-ligands 11a-11e and were obtained via a direct amide linkage to the acrylic acid analogue 11. The biochemical data for conjugates 13a-13e is presented in Table 3. This series of conjugates 13a-13e showed mostly low micromolar activity $\left(\mathrm{IC}_{50}\right.$ range of $1.38-2.5 \mu \mathrm{M}$ ) with two compounds exhibiting sub-micromolar activity ( $\mathrm{IC}_{50}$ values of $0.182 \mu \mathrm{M}$ for $13 \mathrm{e}$ and $0.346 \mu \mathrm{M}$ for $13 \mathrm{~d}$ ). The activity of the conjugates varies depending on the nature of the cycloalkane ring attached and the most active conjugates, $13 \mathrm{~d}$ and $13 \mathrm{e}$ contains the cyclooctane and cyclohexane rings respectively. The compounds $\mathbf{1 3 a} \mathbf{- 1 3 e}$ are predicted to have poor oral absorption with CLogP greater than 5 .

Of the ester linked conjugates, the combretastatin containing compounds $16 \mathbf{a}$ and $\mathbf{1 6 b}$ were the most potent conjugates in this series with antiproliferative activity in MCF-7 cell line of $\mathrm{IC}_{50}=90 \mathrm{nM}$ and $5.7 \mathrm{nM}$ respectively. The cytotxicity of compounds $\mathbf{1 6 a}$ and $\mathbf{1 6} \mathbf{b}$ was determined in the lactate dehydrogenase (LDH) assay to be $13.2 \%$ and $4.1 \%$ respectively, and compares favourably with the cytoxicity of endoxifen $(23 \%)$ and CA-4 $(13 \%)$ when evaluated in the same assay.

\subsection{NCI 60 Cell Line}

The activity of conjugate compound 16a was evaluated using a 60-cell line screen facility of different cancer cell lines of diverse tumour origin in the National Cancer Institute (NCI, Bethesda, MD, USA) Division of Cancer Treatment and Diagnosis (DCTD)/Developmental Therapeutics Programme (DTP). In the one-dose screen, compound 16a displayed very high growth inhibition in the cell lines of colon cancer HCC-2998 (95\%), HCT-116 (98\%), HCT-15 (99\%) and HT29 (93\%); breast cancer BT-549 (94\%), MCF-7 (90\%) and MDA-MB-468 (99\%); melanoma M14 (99\%); CNS cancer SF-295 (94\%) and U251 (90\%) when evaluated at $10 \mu \mathrm{M}$ concentration. The compound caused between $80-89 \%$ growth inhibition in a further 10 cell lines. The compound 16a displayed $\mathrm{GI}_{50}\left(\mathrm{IC}_{50}\right)$ values within the range $10-72 \mathrm{nM}$ for most of the 60 cancer cell lines. Compound 16a displayed a $\mathrm{GI}_{50}\left(\mathrm{IC}_{50}\right)$ value of $36 \mathrm{nM}$ and a $\mathrm{LC}_{50}$ value greater than $100 \mu \mathrm{M}$ in the MCF-7 breast cancer cell line, (Table 4), indicating a significant therapeutic window between the concentration required for inhibition of cancer cell growth, and the concentration that is determined to be toxic to MCF-7 breast cancer cells. 
Table 4. In vitro human cancer cell growth inhibition for compound $\mathbf{1 6 a}^{a}$ : Antiproliferative evaluation in the NCI60 cell line in vitro screen.

\begin{tabular}{|c|c|c|c|c|c|}
\hline \multirow{2}{*}{ Cell Line } & Compound 16a & Compound 16a & \multirow{2}{*}{ Cell Line } & \multirow{2}{*}{$\begin{array}{c}\text { Compound 16a } \\
\text { Growth } \%\left(10^{-5} \mathrm{M}\right)^{a}\end{array}$} & \multirow{2}{*}{$\begin{array}{l}\text { Compound 16a } \\
\qquad \mathrm{GI}_{50}(\mu \mathrm{M})^{\mathrm{b}}\end{array}$} \\
\hline & Growth $\%\left(10^{-5} \mathrm{M}\right)^{a}$ & $\mathrm{GI}_{50}(\mu \mathrm{M})^{\mathrm{b}}$ & & & \\
\hline Leukemia & & & Melanoma & & \\
\hline CCRF-CEM & 20.38 & 0.0394 & LOX IMV1 & 28.97 & 0.0358 \\
\hline HL-60(TB) & 28.19 & 0.0145 & MALME-3M & 74.86 & $>10.00$ \\
\hline K-562 & 41.7 & $<0.0100$ & M14 & 1.39 & 0.0129 \\
\hline MOLT-4 & 36.2 & 0.0398 & MDA-MB-435 & $-16.61^{\mathrm{e}}$ & $<0.0100$ \\
\hline RPMI-8226 & $-18.51^{\mathrm{e}}$ & 0.0271 & SK-MEL-2 & 37.97 & $>10.00$ \\
\hline SR & 29.68 & 0.0189 & SK-MEL-28 & 89.31 & $<0.0100$ \\
\hline $\begin{array}{l}\text { Non-Small Cell } \\
\text { Lung Cancer }\end{array}$ & & & SK-MEL-5 & $-34.34^{e}$ & 0.0201 \\
\hline A549/ATCC & 18.56 & 0.059 & UACC-257 & 48.73 & $>10.00$ \\
\hline EKVX & 22.72 & 0.0569 & UACC-62 & 25.13 & 0.0181 \\
\hline HOP-62 & 35.29 & 0.0492 & Ovarian cancer & & \\
\hline HOP-92 & 58.55 & $<0.0100$ & $\begin{array}{c}\text { IGROV1 } \\
\text { OVCAR-3 }\end{array}$ & $\begin{array}{l}-26.34 \mathrm{e} \\
-57.79^{\mathrm{e}}\end{array}$ & $\begin{array}{c}0.0473 \\
<0.0100\end{array}$ \\
\hline NCI-H226 & 11.59 & 0.0471 & OVCAR-4 & 30.96 & 0.0628 \\
\hline NCI-H23 & 12.25 & 0.0459 & OVCAR-5 & 34.65 & 0.0894 \\
\hline NCI-H332M & 57.18 & 0.0672 & OVCAR-8 & 12.79 & 0.049 \\
\hline NCI-H460 & $-6.77^{e}$ & 0.0299 & NCI/ADR-RES & $-41.32^{\mathrm{e}}$ & 0.0111 \\
\hline NCI-H552 & $-30.85^{\mathrm{e}}$ & 0.0197 & SK-OV-3 & 17.23 & 0.0368 \\
\hline Colon Cancer & & & Renal cancer & & \\
\hline COLO 205 & $-55^{\mathrm{e}}$ & 0.378 & $786-0$ & 11.54 & 0.185 \\
\hline HCT-2998 & 4.72 & 0.0317 & A498 & 29.47 & 0.0581 \\
\hline НСТ-116 & 1.61 & 0.0156 & $\mathrm{ACHN}$ & 22.73 & 0.0455 \\
\hline НCT-15 & 0.71 & 0.0245 & CAKI-1 & 23.4 & 0.0307 \\
\hline HT29 & 6.79 & 0.489 & RXF 393 & 12.08 & 0.0398 \\
\hline KM12 & $-37^{\mathrm{e}}$ & $<0.0100$ & SN12C & 31.84 & 0.0576 \\
\hline SW-620 & 28.17 & $<0.0100$ & TK-10 & 33.77 & 0.589 \\
\hline CNS Cancer & & & UO-31 & 31.52 & 0.0884 \\
\hline SF-268 & 18.51 & 0.0253 & Breast cancer & & \\
\hline SF295 & 6.21 & 0.0208 & MCF-7 & 10.06 & 0.0345 \\
\hline SF539 & $-7.31^{\mathrm{e}}$ & 0.0213 & MDA-MB-231/ATCC & 23.19 & 0.0286 \\
\hline SNB-19 & 28.03 & 0.0365 & HS 578T & 17.57 & 0.0255 \\
\hline SNB-75 & 39.46 & 0.0166 & BT-549 & 7.07 & 0.0438 \\
\hline U251 & 10.13 & 0.0316 & $\mathrm{~T}-47 \mathrm{D}$ & 59.73 & $>10$ \\
\hline Prostate cancer & & & MDA-MB-468 & 0.68 & 0.0343 \\
\hline PC-3 & 19.1 & 0.012 & $\underset{c}{\text { MG-MID }(\mu M)}$ & - & 1.62 \\
\hline DU-145 & $-36.33^{e}$ & 0.0125 & $\begin{array}{c}M G \%\left(10^{-5}\right. \\
M)^{d}\end{array}$ & 14.74 & - \\
\hline
\end{tabular}

${ }^{a}$ Data obtained from NCI in vitro human tumour cell screen at $10 \mu \mathrm{M}$ concentration. ${ }^{\mathrm{b}} \mathrm{GI}_{50}$ is the molar concentration of the compound causing 50\% inhibition of growth of the tumour cells. ${ }^{c}$ MG-MID: the mean of $\mathrm{GI}_{50}$ values over all cell lines for the tested compound. ${ }^{\mathrm{d}} \mathrm{MG} \%\left(10^{-5} \mathrm{M}\right)$ : Mean Growth \% over all cell lines for the tested compound. ${ }^{\text {e }}$ Cytotoxic effect.

As 16a does not display selectivity and enhanced activity towards the ER-positive cell line, it suggests that 16a may be exerting its potent activity by other biological mechanisms (i.e., inhibition of tubulin polymerisation) other than through the ER alone. Again, this is a promising result and highlights the possible therapeutic applications for the prototype ER-conjugates. Future research is being undertaken to determine what other mechnisms this compounds may inhibit in cancer cells. For 16a the COMPARE analysis was run on a database of common anti-cancer agents (JobID: 37888) and the larger more comprehensive database including natural products and other submitted agents (JobID: 37889). The highest correlation coefficient achieved was 0.629 in relation to the synthetic nucleoside antitumour, DNA and RNA synthesis inhibitor tiazofurin [66]. CA-4 15 was listed as a high-ranking hit with a correlation coefficient of 0.658 . A correlation coefficient of above 0.6 is considered a positive correlation. This result supports the suggestion that the combretastatin moiety plays an important role in the activity profile of this ester-conjugate as it has a similar pattern or mechanism of action. 


\subsection{Estrogen Receptor Binding Studies}

It was necessary to test the binding efficiency of each compound for both ER isoforms (ER $\alpha$ and $\mathrm{ER} \beta$ ), to determine how effectively the ligand binds to the receptor and whether the compound is acting as an antagonist or agonist. The competitive binding experiments were conducted using a fluorescence polarization assay which consists of purified baculovirus expressed human $\operatorname{ER} \alpha$ and $\operatorname{ER} \beta$ and fluoromone, a fluorescein labelled estrogen ligand $[67,68]$. The most active SERM type compounds and conjugates incorporating an ER type ligand from the antiproliferative assay were selected for ER binding study. The selectivity value reported is the ratio of relative binding affinity (RBA) values ER $\alpha$ relative to $E R \beta$, for each of the compounds. For selectivity values greater than 1, the compounds have a more pronounced affinity for ER $\alpha$ binding site, while for values less than 1, the compounds have a more pronounced affinity for the ER $\beta$ binding site.

The most potent compounds evaluated for both $E R \alpha$ and $E R \beta$ affinity exhibit impressive binding activity. Compound $3 \mathbf{i}$ displayed ER binding activity in the nanomolar region for both ER isoforms $\left(\mathrm{IC}_{50} \mathrm{ER} \alpha 182 \mathrm{nM}\right.$ and $\mathrm{IC}_{50} \mathrm{ER} \beta 436 \mathrm{nM}$ ), with selectivity (3.13) for ER $\alpha$ thus demonstrating that the incorporation of a combretastatin-endoxifen hybrid scaffold structure results in a compound with potential SERM properties. The cyclofenil type compounds 11c and 11e display nanomolar activity in $\mathrm{ER} \beta\left(\mathrm{IC}_{50}=199 \mathrm{nM}\right.$ and $\mathrm{IC}_{50}=67 \mathrm{nM}$ respectively) and low micromolar activity in ER $\alpha$ $\left(\mathrm{IC}_{50}=1.738 \mu \mathrm{M}\right.$ and $\mathrm{IC}_{50}=3.162 \mu \mathrm{M}$ respectively), with selectivity for ER $\beta$ in both cases. Compound 11e which was a cyclofenil type ligand, exhibited the greatest selectivity (46 fold) towards the ER $\beta$ isoform while compound 13e which was a direct conjugate of 11e displayed the greatest selectivity (12.3 fold) towards ER $\alpha$. The corresponding cyclofenil conjugate 13e demonstrated potent nanomolar binding activity for $\operatorname{ER} \alpha\left(\mathrm{IC}_{50}=19.0 \mathrm{nM}\right)$ and $\mathrm{ER} \beta\left(\mathrm{IC}_{50}=229 \mathrm{nM}\right)$.

The CA4 conjugate $\mathbf{1 6 b}$ displays significant ER binding affinities which help explain the antiproliferative activity of the conjugate. Interestingly the succinic-endoxifen linker compound 14c displays potent binding affinities in both $\mathrm{ER} \alpha$ and $\mathrm{ER} \beta$ with competitive binding $\mathrm{IC}_{50}$ values of $11.3 \mathrm{nM}(\mathrm{ER} \alpha)$ and $6.7 \mathrm{nM}(\mathrm{ER} \beta)$. These values represent an approximately 3-fold increase in binding affinity in both ER isoforms when compared to 4-hydroxytamoxifen. The carboxylic acid group may interact favourably with a residue in the binding site. Interestingly, the carboxylic acids such as 14a (Table 3) closely related (differing only in the hydroxy moiety on the triarylethylene aryl ring scaffold) displayed no significant antiproliferative activity.

As in the antiproliferative assays, the conjugate $16 \mathrm{~b}$ demonstrated impressive ER binding results and is suitable as a possible lead compound for further development. The conjugate displays nanomolar binding to the $\mathrm{ER} \alpha$ and $\mathrm{ER} \beta,\left[\mathrm{IC}_{50} \mathrm{ER} \alpha 52.1 \mathrm{nM}\right.$ and $\mathrm{IC}_{50} \mathrm{ER} \beta 115 \mathrm{nM}$ ]. The phenolic hydroxy functionality present on the endoxifen fragment can interact favourably with the residues Glu353, Arg394 and His524 in the ER binding site through hydrogen bonding which can explain the high binding affinity. The combretastatin fragment may also form favourable interactions in the binding site as there is comparable ER $\alpha$ binding affinity with endoxifen. Presumably, the hydroxy functionality present on the combretastatin fragment is involved in hydrogen bonding.

Often the relative binding affinity (RBA) of estrogen receptor ligands is reported. Estradiol is typically used as the reference ligand and is taken as the $100 \%$ binding value. Using the reference $\mathrm{IC}_{50}$ values obtained from the literature for estradiol in the $\mathrm{ER} \alpha(5.7 \mathrm{nM})$ and $\mathrm{ER} \beta(5.6 \mathrm{nM})$, the RBAs of the selected conjugates were calculated (see Table 5). All of the conjugates investigated in the ER competitive binding assays had RBA values greater than or equal to $1 \%$. The RBA values between of $5-16 \%$ would be considered moderate binding while the RBA value for 14c demonstrates strong RBA $\mathrm{ER} \alpha=50.44, \mathrm{ER} \beta=83.6$. The lead conjugates e.g., 13e and $\mathbf{1 6} \mathbf{b}$ display very impressive RBA values of $\mathrm{ER} \alpha=30$ and $\mathrm{ER} \beta 2.44$ for $\mathbf{1 3 e}$ and $\mathrm{ER} \alpha=10.94, \mathrm{ER} \beta 4.87$ for $\mathbf{1 6 b}$. 
Table 5. Estrogen receptor binding affinities for compounds ${ }^{\mathrm{a}}$.

\begin{tabular}{|c|c|c|c|c|c|}
\hline Compound & $\mathrm{ER} \alpha \mathrm{IC}_{50}(\mathrm{nM})^{\mathrm{a}, \mathrm{b}}$ & $\mathrm{ER} \beta \mathrm{IC}_{50}(\mathrm{nM})^{\mathrm{a}, \mathrm{b}}$ & $E R \alpha R_{B A}^{c}$ & $E R \beta R_{B A}{ }^{c}$ & Selectivity $(\alpha / \beta)$ \\
\hline $3 \mathbf{i}$ & 182 & 436 & 3.13 & 1.28 & 2.44 \\
\hline $11 \mathrm{c}$ & 1738 & 199 & 0.328 & 2.81 & 0.12 \\
\hline 11d & 170 & 112 & 3.35 & 5.00 & 0.67 \\
\hline $11 \mathrm{e}$ & 3162 & 67.0 & 0.180 & 8.35 & 0.02 \\
\hline $13 \mathrm{e}$ & 19.0 & 229 & 30.0 & 2.44 & 12.3 \\
\hline $14 \mathrm{c}$ & 11.3 & 6.7 & 50.44 & 83.6 & 0.60 \\
\hline $16 a$ & 79.9 & 22.7 & 7.13 & 24.66 & 0.29 \\
\hline $16 b$ & 52.1 & 115 & 10.94 & 4.87 & 2.25 \\
\hline $16 c$ & 70.9 & 90.1 & 8.04 & 6.22 & 1.29 \\
\hline Endoxifen & 47.0 & 118 & 12.1 & 4.75 & 2.55 \\
\hline 4-Hydroxytamoxifen & 30.0 & 26.1 & 19.0 & 21.5 & 0.88 \\
\hline Estradiol & 5.7 & 5.6 & - & - & 0.98 \\
\hline
\end{tabular}

${ }^{a}$ Mean $\mathrm{IC}_{50}$ values of compounds for their competitive binding in $\mathrm{ER} \alpha$ and $\mathrm{ER} \beta$ isoforms. ${ }^{\mathrm{b}}$ Values are an average of at least nine replicate experiments, for ER $\alpha$ with typical standard errors below $15 \%$, and six replicate experiments for ER $\beta$, with typical standard errors below $15 \% .{ }^{c}$ The relative binding affinity (RBA) of ER ligands is reported, using $\mathrm{IC}_{50}$ values for estradiol as the reference ligand [ER $\alpha(5.7 \mathrm{nM})$ and $\operatorname{ER} \beta(5.6 \mathrm{nM}) ; 100 \%$ binding value.]

\subsection{Effects of Selected Active Compounds on Cell Cycle and Cell Death.}

Based on the cell viability assay results, a selected cohort of the most active compounds from each series ( $\mathrm{IC}_{50}$ values $0.182-4.57 \mu \mathrm{M}$ ) were subjected to cell cycle analysis, Figure 2 . Flow cytometry with propidium iodide stained cells was carried out to analyse the percentage of cells in each stage of the cell cycle and the number of apoptotic or dead cells. Samples were treated for $72 \mathrm{~h}$ at $10 \mu \mathrm{M}$. Results showed that all compounds tested increased apoptosis when compared to vehicle-treated cells. Of the active compounds, the cyclofenil based analogues 11c and 11e proved significantly more active than the positive control tamoxifen $(p$ value $<0.001)$. The most potent compound tested, 11c induced $79.7 \pm 5.2 \%$ apoptosis at $10 \mu \mathrm{M}$ while compound 11e induced $76 \%$ apoptosis. Conjugates $13 \mathbf{c}, \mathbf{1 3} \mathbf{d}$ and 13e demonstrated pro-apoptotic effects of $20 \%, 36 \%$ and $48 \%$ respectively.

Interestingly, in addition to inducing apoptosis, the CA4 direct amide cyclofenil based conjugate 13d ( $p$ value $<0.01$ ) also induced a significant G2/M-arrest $(27 \%)$ in MCF-7 cells when compared to vehicle-treated cells, with 13e causing a lesser effect on G2M arrest of 18\%. A G2/M arrest typically, though not necessarily always, precedes apoptosis. Future studies at earlier time-points ( $24 \mathrm{~h}$ and $48 \mathrm{~h}$ ) will be undertaken to establish if the other active compounds in this cohort also induce a G2/M arrest preceding apoptosis. A G2/M arrest is commonly observed with tubulin-targeting compounds and so this data suggests that the tubulin-targeting ability of combretastatins is maintained when complexed to various ligands with induction of significant apoptosis.

Next, the same cohort of compounds was tested on peripheral blood mononuclear cells (PBMCs) isolated from the blood of healthy donors. Cells were treated with $10 \mu \mathrm{M}$ of each compound for $72 \mathrm{~h}$ and subjected to flow cytometry. Results showed that only two of the compounds, (11c and 11e), the most active compounds in the MCF-7 cells), induced apoptosis in PBMCs, with no toxic effects observed with the other compounds. None of the compounds caused a G2/M arrest in PBMCs. The potent activity of $\mathbf{1 3} \mathbf{d}, \mathbf{1 3} \mathbf{e}$ and $\mathbf{3 i}$ of this cohort of compounds in MCF-7 breast cancer cells and their lack of toxicity in normal PBMCs make them ideal candidates for further anti-cancer studies. 


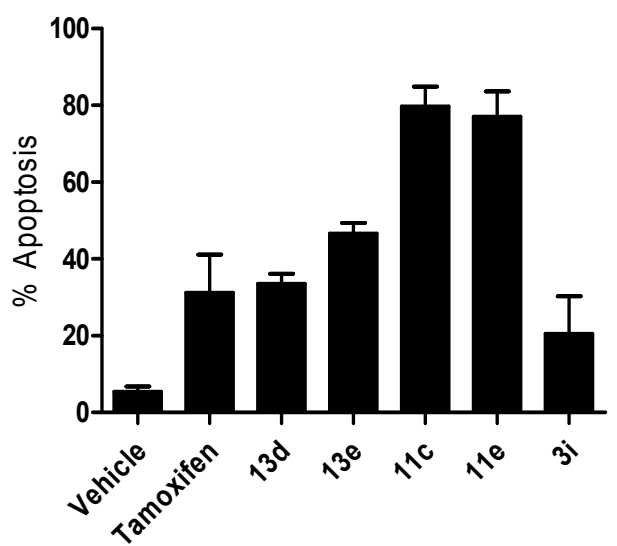

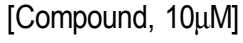

(A)

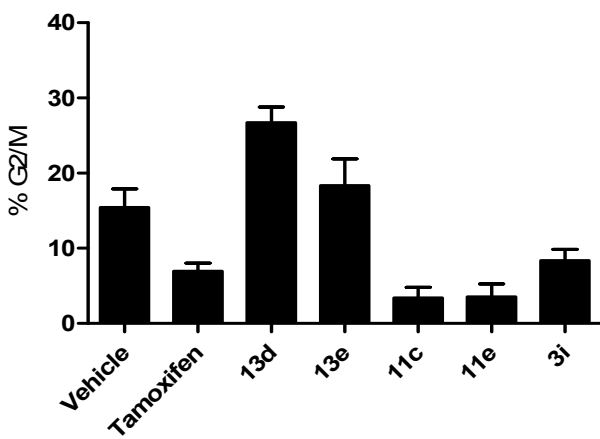

[Compound, $10 \mu \mathrm{M}$ ]

(C)

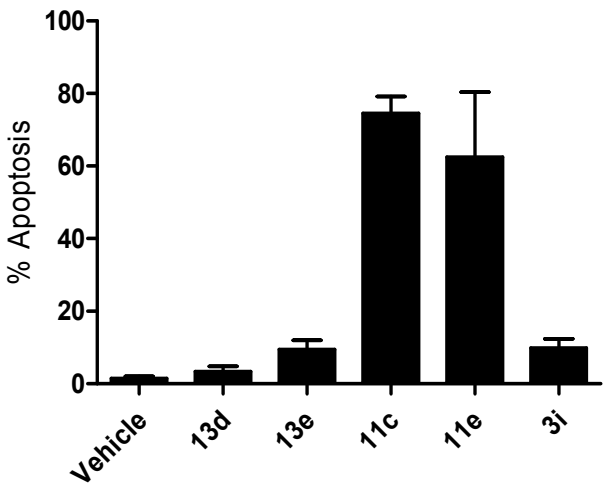

[Compound, 10 $\mu \mathrm{M}$ ]

(B)

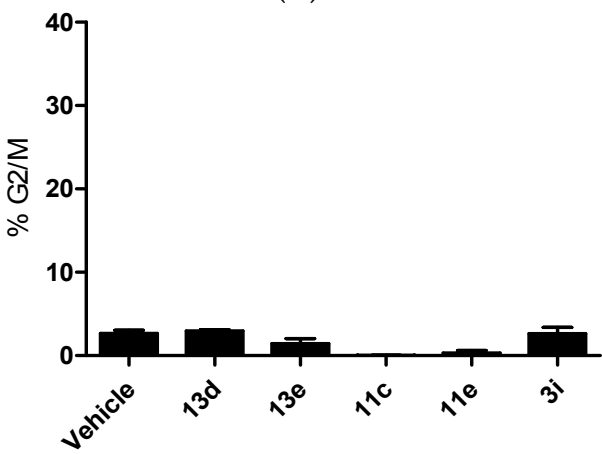

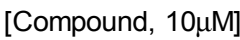

(D)

Figure 2. Compounds 3i, 11c, 11e, 13d and 13e potently induce apoptosis in MCF-7 cells, but not healthy PBMCs. Cells were treated for $72 \mathrm{~h}$ with a vehicle or the indicated compounds. After the required incubation period, cells were fixed in $1 \mathrm{~mL}$ ethanol and $100 \mu \mathrm{L}$ PBS and stained with propidium iodide. Cells were subsequently analysed by flow cytometry to determine the percentage of apoptotic (A) MCF-7 cells and (B) PBMCs and G2/M-arrested (C) MCF-7 cells and (D) PBMCs. Values represent the mean \pm SEM of three independent experiments.

\subsection{Molecular Modelling of 11e, $\mathbf{1 6 b}$ and $\mathbf{1 3 e}$ in ER $\alpha$ and $E R \beta$}

A retrospective molecular modelling study of $11 \mathrm{e}, \mathbf{1 6 b}$ and $13 \mathrm{e}$ was undertaken to rationalise the selectivity profile differences of the compounds for ER $\alpha$ and ER $\beta$. Two amino acid differences within the ligand binding pocket of the ER isoforms are replacement of Met412 and Leu384 in ER $\alpha$ with Ile373 and Met336 respectively in ER $\beta$ which have an impact on the following results.

The 3ERT X-ray structure of hER $\alpha$ co-crystallised with 4-hydroxytamoxifen (4-OHT) [69] was downloaded from the PDB website. For ER $\beta$ the 1NDE X-ray structure co-crystallised with a triazine modulator was used [70]. An in-depth binding poses analysis on compounds 11e, 16b and 13e was performed. The top five docked poses of each compound in each isoform were analysed and mapping to the $\mathrm{X}$-ray structure ligands binding poses was considered. Amino acid numbering corresponds to $\mathrm{AA}(\# \mathrm{ER} \alpha) /(\# \mathrm{ER} \beta)$ unless specified in the text. 


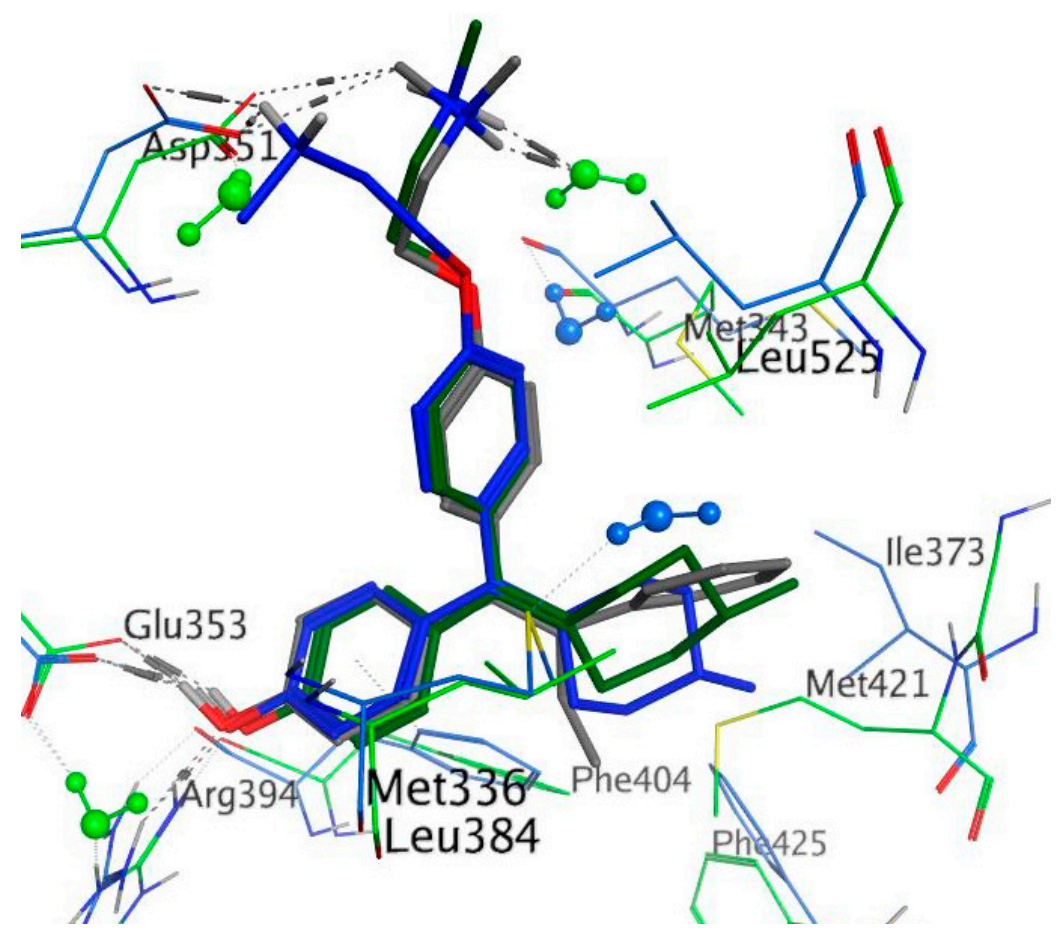

Figure 3. Ranked poses of 11e in ER $\alpha$ and ER $\beta$ overlaid on 4-OHT X-ray structure. Carbon atoms of 11e are illustrated in dark green in ER $\alpha$, dark blue in ER $\beta$ and grey in 4-OHT (oxygen atoms are red; nitrogen in dark blue; sulphur in yellow). ER $\alpha$ and associated water molecules are in light green, $E R \beta$ and associated water molecules are in light blue. Amino acid numbering is for ER $\alpha$ except when different in ER $\beta$ where both labels are used. PDB structures 3ERT [69] and 1NDE [70] were used for molecular docking.

11e docked well into both ER isoforms and recapitulated the interactions formed by 4-OHT in the 3ERT X-ray structure. The 4-methylcyclohexylidene moiety occupies a hydrophobic pocket delineated by Leu525, Met343, Met421 (Ile373 in ER $\beta$ ) and Leu384 (Met336 in ER $\beta$ ). In ER $\alpha$ each of these amino acids are closer to the ligand and form a tighter binding sub-pocket than for ER $\beta$. In 4-OHT the D-ring phenyl group occupies this sub-pocket and is a planar conformationally rigid structure but the corresponding moiety in 11e is 4-methylcyclohexylidene which is bulkier and converts between multiple conformational states. This results in clashing with the more tightly packed ER $\alpha$ amino acids. Additionally, in ER $\beta$ Leu384 is mutated to Met336 which, in the 1NDE X-ray structure, forms a hydrogen bond acceptor interaction (HBA) with a cocrystallised water molecule, thereby decreasing the hydrophobicity of the sub-pocket. Both of these factors result in a 47-fold binding affinity preference for ER $\beta$ over ER $\alpha$ of this compound. The similarities in overlays between 11e docked in ER $\alpha$ and ER $\beta$ is illustrated in Figure 3.

Docking of compound 13e in ER $\alpha$ retained the same 4-OHT mapping binding mode as observed for 11e. Analogous to the situation with $\mathbf{1 6 b}$, the methylamide moiety of 13e would clash with Leu476 of $E R \beta$ so the ligand is significantly shifted upwards thereby unable to make optimal interactions within the binding pocket. This is reflected in the 12-fold selectivity of the ligand for ER $\alpha$ over ER $\beta$ and is shown in Figure 4. 


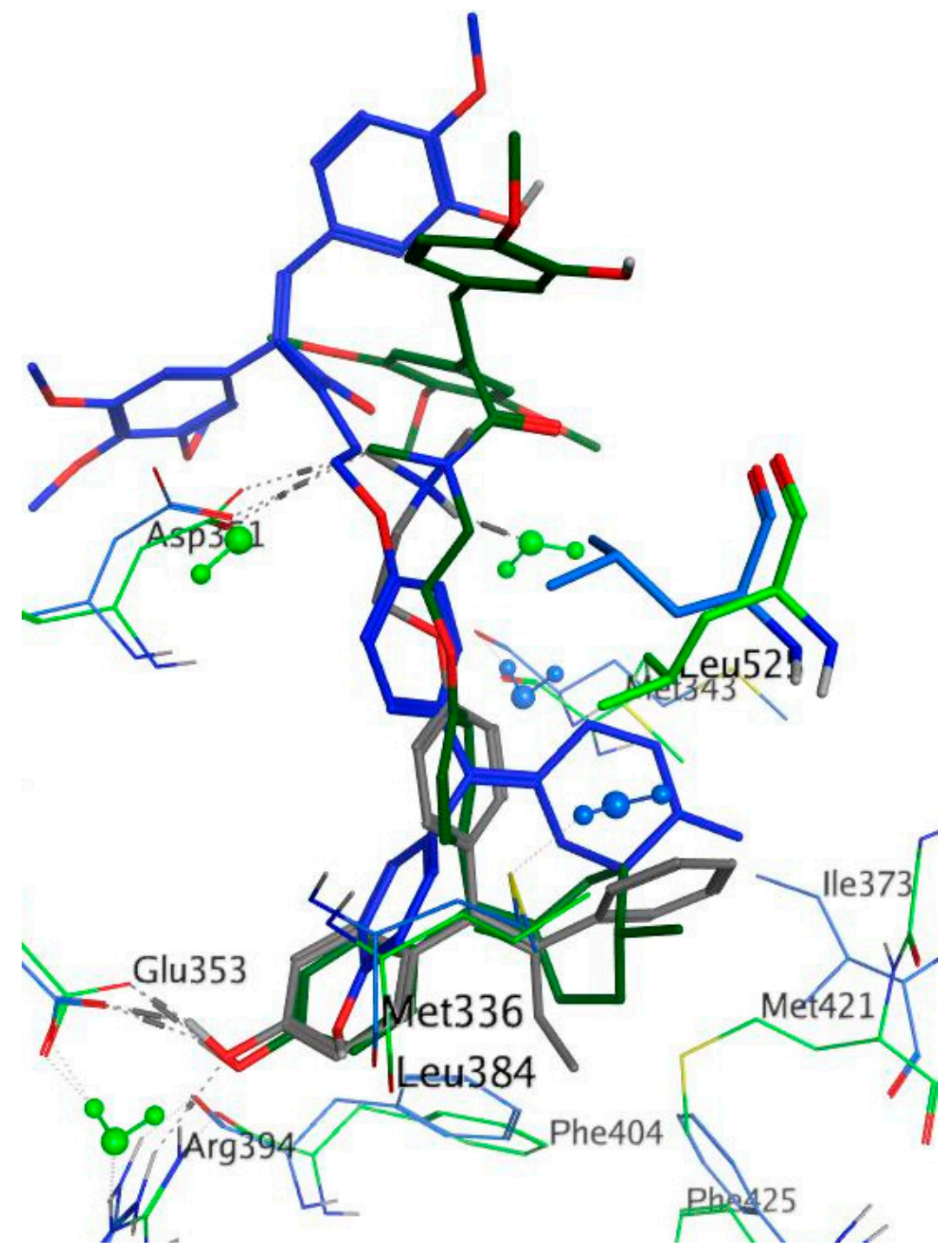

Figure 4. Ranked poses of 13e in ER $\alpha$ and ER $\beta$ overlaid on 4-OHT X-ray structure. The potential clashing interaction between Leu525/476 (rendered in tube style) of ER $\beta$ with the methylamide of 13e is present. Carbon atoms of 13e are illustrated in dark green in ER $\alpha$, dark blue in ER $\beta$ and grey in 4-OHT (oxygen atoms are red; nitrogen in dark blue; sulphur in yellow). ER $\alpha$ and associated water molecules are in light green, ER $\beta$ and associated water molecules are in light blue. Amino acid numbering is for ER $\alpha$ except when different in ER $\beta$ where both labels are used. PDB structures 3ERT [69] and 1NDE [70] were used for molecular docking.

16b docked with a perfect overlay on the ER $\alpha$ OHT X-ray. The corresponding docked pose in ER $\beta$ is capable of making the same hydrogen bond donor (HBD) interaction as the 4-OHT A-ring phenolic oxygen atom but the ligand is shifted upwards in the binding site. A contributing factor to this is the repositioning of Leu525/476 which is adjacent to the 4-OHT C-ring in ER $\alpha$ but flipped $180^{\circ}$ upwards towards the binding pocket entrance in ER $\beta$.

As highlighted with a red circle in Figure 5, this repositioned Leu now clashes with the methylamide of the side-chain of $\mathbf{1 6 b}$ in ER $\beta$ so the ligand is shifted away and twisted so as to avoid electrostatic repulsion between the amide carbonyl oxygen atom and Asp351/303. This is revealed in a 7-fold binding affinity preference for ER $\alpha$ over ER $\beta$. 


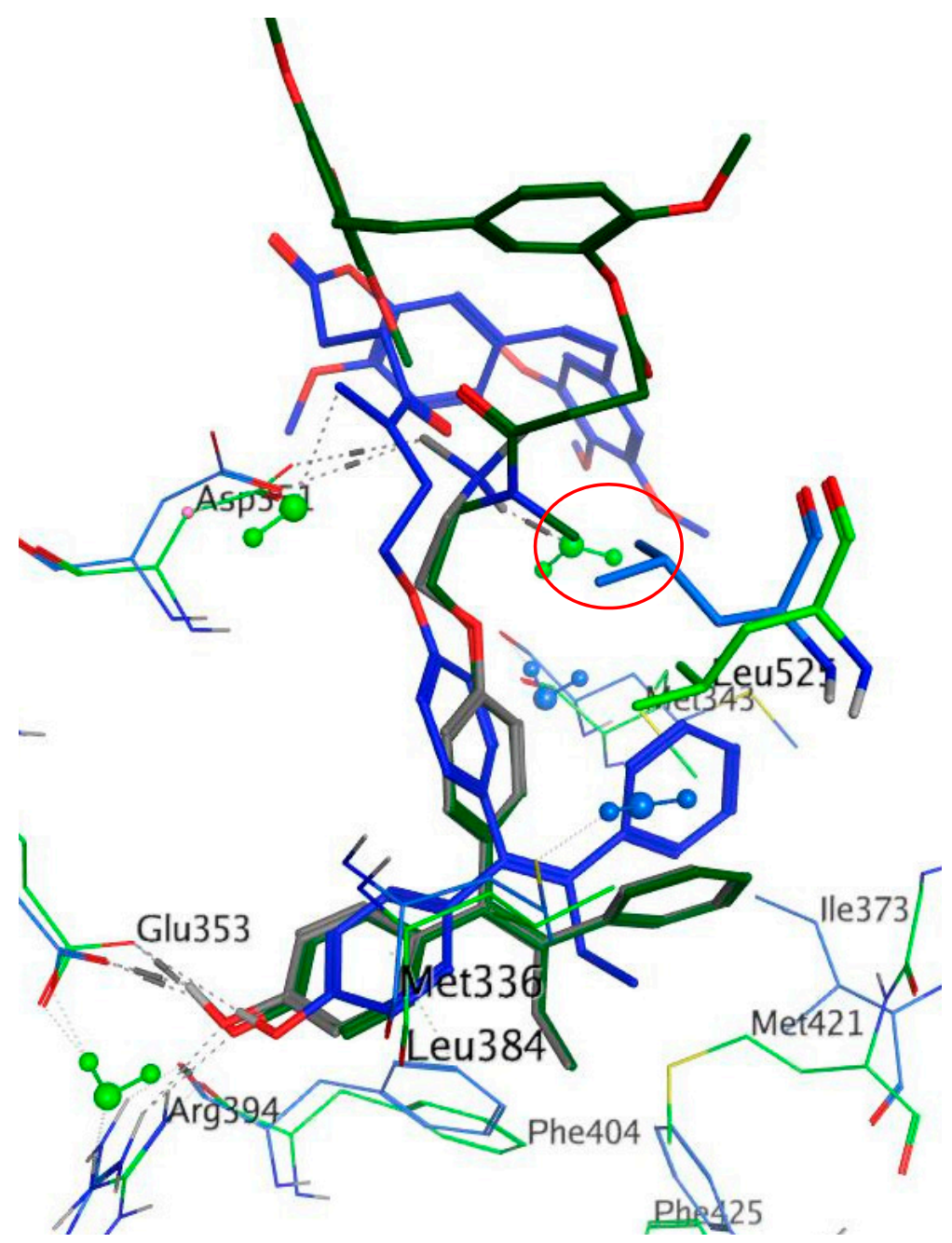

Figure 5. Ranked poses of $\mathbf{1 6 b}$ in ER $\alpha$ and ER $\beta$ overlaid on 4-OHT X-ray structure. The potential clashing interaction between Leu525/476 (rendered in tube style) of ER $\beta$ with the methylamide of $\mathbf{1 6 b}$ is circled in red. Carbon atoms of $\mathbf{1 6 b}$ are illustrated in dark green in ER $\alpha$, dark blue in ER $\beta$ and grey in 4-OHT (oxygen atoms are red; nitrogen in dark blue; sulphur in yellow). ER $\alpha$ and associated water molecules are in light green, ER $\beta$ and associated water molecules are in light blue. Amino acid numbering is for ER $\alpha$ except when different in $E R \beta$ where both labels are used. PDB structures 3ERT [69] and 1NDE [70] were used for molecular docking.

\section{Experimental Section}

\subsection{General Information}

All reagents were commercially available and were used without further purification unless otherwise indicated [19]. Tetrahydrofuran (THF) was distilled immediately prior to use from $\mathrm{Na} /$ Benzophenone under a slight positive pressure of nitrogen, toluene was dried by distillation from sodium and stored on activated molecular sieves $(4 \AA)$ and dichloromethane was dried by distillation from calcium hydride prior to use. Uncorrected melting points were measured on a Gallenkamp apparatus. Infra-red (IR) spectra were recorded as thin film on $\mathrm{NaCl}$ plates, or as potassium bromide discs on a Perkin Elmer FT-IR Specrtum 100 spectrometer (Perkin Elmer, Waltham, MA, USA). ${ }^{1} \mathrm{H}$ - and ${ }^{13} \mathrm{C}$-nuclear magnetic resonance (NMR) spectra were recorded at $27{ }^{\circ} \mathrm{C}$ on a Bruker Avance DPX 400 spectrometer $\left(400.13 \mathrm{MHz},{ }^{1} \mathrm{H} ; 100.61 \mathrm{MHz},{ }^{13} \mathrm{C}\right)$ (Bruker, Billerica, MA, USA) at $20{ }^{\circ} \mathrm{C}$ in $\mathrm{CDCl}_{3}$ (internal standard tetramethylsilane (TMS)), $\mathrm{CD}_{3} \mathrm{OD}$ or DMSO- $d_{6}$ by Dr. John O'Brien and 
Dr. Manuel Ruether in the School of Chemistry, Trinity College Dublin. For $\mathrm{CDCl}_{3},{ }^{1} \mathrm{H}-\mathrm{NMR}$ spectra were assigned relative to the TMS peak at $0.00 \delta$ and ${ }^{13} \mathrm{C}$-NMR spectra were assigned relative to the middle $\mathrm{CDCl}_{3}$ triplet at $77.00 \mathrm{ppm}$. For $\mathrm{CD}_{3} \mathrm{OD},{ }^{1} \mathrm{H}$ and ${ }^{13} \mathrm{C}-\mathrm{NMR}$ spectra were assigned relative to the centre peaks of the $\mathrm{CD}_{3} \mathrm{OD}$ multiplets at $3.30 \delta$ and $49.00 \mathrm{ppm}$ respectively. Electrospray ionisation mass spectrometry (ESI-MS) was performed in the positive ion mode on a liquid chromatography time-of-flight (TOF) mass spectrometer (Micromass LCT, Waters Ltd., Manchester, UK), equipped with electrospray ionization (ES) interface operated in the positive ion mode at the High Resolution Mass Spectrometry Laboratory by Dr. Martin Feeney in the School of Chemistry, Trinity College. Mass measurement accuracies of $< \pm 5 \mathrm{ppm}$ were obtained. Low resolution mass spectra (LRMS) were acquired on a Hewlett-Packard 5973 MSD GC-MS system (Hewlett-Packard, Palo Alto, CA, USA) in electron impact (EI) mode. $R_{f}$ values are quoted for thin layer chromatography on silica gel F-254 plates (Merck, Kenilworth, NJ, USA) unless otherwise stated. Compounds were visually detected with UV at 254 and $366 \mathrm{~nm}$. Flash column chromatography was carried out on Merck Kieselgel 60 (particle size $0.040-0.063 \mathrm{~mm}$ ), aluminium oxide, (activated, neutral, Brockmann I, 50 mesh, Aldrich, Darmstadt, Germany) or Aldrich aluminium oxide, (activated, acidic, Brockmann I, 50 mesh). All products isolated were homogenous on TLC. Analytical high-performance liquid chromatography (HPLC) to determine the purity of the final compounds was performed using a Waters 2487 Dual Wavelength Absorbance detector, a Waters 1525 binary HPLC pump, a Waters In-Line Degasser AF and a Waters 717 plus Autosampler (Waters Corporation, Milford, MA 01757, USA). The column used was a Varian Pursuit XRs C18 reverse phase $150 \times 4.6 \mathrm{~mm}$ chromatography column (Agilent, Santa Clara, CA, USA). Samples were detected using a wavelength of $254 \mathrm{~nm}$. All samples were analyzed using acetonitrile (70\%): water (30\%) over $10 \mathrm{~min}$ and a flow rate of $1 \mathrm{~mL} / \mathrm{min}$. Unless otherwise indicated, the purity of the final products was $\geq 95 \%$. Chromatograpic separations were also carried out on Biotage SP4 instrument (Biotage AB, Uppsala, Sweden). Microwave experiments were carried out with the Biotage Initiator and Discover CEM microwave synthesisers. Combretastatin A-4 (CA4) 15 [50,52] and the acrylic acids 1a [71], 1b [72], 1d [73], 1e [73], 1g [74], 1i [75], 11 [76], 1m [77], 1n [50], 1s [50] were prepared as previously reported.

\subsection{Chemistry}

\subsubsection{General Method for Synthesis of Acrylic Acids 1a-1r}

Method A: A mixture of the appropriate the appropriate phenylacetic acid ( $0.50 \mathrm{~g}, 1$ equivalent), benzaldehyde (1 equivalent), acetic anhydride $(2 \mathrm{~mL})$ and triethylamine $(1 \mathrm{~mL})$ were heated under reflux for $3-5 \mathrm{~h}$. After acidification with concentrated hydrochloric acid $(5 \mathrm{~mL})$, the resulting solid was filtered off and recrystallised to yield the required acrylic acid. Method B: A mixture of the appropriate benzaldehyde (1 eq.), the appropriate phenylacetic acid (700 $\mathrm{mg}, 1 \mathrm{eq}$.$) , acetic anhydride$ $(2 \mathrm{~mL})$ and triethylamine $(1 \mathrm{~mL})$ were reacted in the microwave reactor at a $120^{\circ} \mathrm{C}$ and for $30 \mathrm{~min}$. After acidification with concentrated hydrochloric acid $(5 \mathrm{~mL})$, the resulting solid was filtered and recrystallised to afford the required acrylic acid.

(E)-2,3-bis(3,4,5-Trimethoxyphenyl)acrylic acid (1c). 3,4,5-Trimethoxybenzaldehyde (700 mg, $3.59 \mathrm{mmol})$ and 3,4,5-trimethoxyphenylacetic acid $(744 \mathrm{mg}$, $3.59 \mathrm{mmol})$ were reacted following the general method A. Recrystallisation from methanol afforded the acrylic acid as fine yellow solid (484 $\mathrm{mg}, 33 \%$ ). 3,4,5-Trimethoxybenzaldehyde $(606 \mathrm{mg}, 3.09 \mathrm{mmol})$ and 3,4,5-trimethoxyphenylacetic acid $(700 \mathrm{mg}$, $3.09 \mathrm{mmol}$ ) were reacted following the general method B. Recrystallisation from methanol afforded the acrylic acid as fine yellow solid $(1.2 \mathrm{~g}, 96 \%)$, m.p. $169-172{ }^{\circ} \mathrm{C} .{ }^{1} \mathrm{H}-\mathrm{NMR}\left(\mathrm{CDCl}_{3}\right): \delta 7.85(\mathrm{~s}, 1 \mathrm{H}$, $\mathrm{C}=\mathrm{CH}), 6.53(\mathrm{~s}, 2 \mathrm{H}, \mathrm{Ar}-\mathrm{H}), 6.42(\mathrm{~s}, 2 \mathrm{H}, \mathrm{Ar}-\mathrm{H}), 3.88\left(\mathrm{~s}, 3 \mathrm{H}, \mathrm{OCH}_{3}\right), 3.85\left(\mathrm{~s}, 3 \mathrm{H}, \mathrm{OCH}_{3}\right), 3.83(\mathrm{~s}, 6 \mathrm{H}$, $\left.2 \times \mathrm{OCH}_{3}\right), 3.63\left(\mathrm{~s}, 6 \mathrm{H}, 2 \times \mathrm{OCH}_{3}\right) .{ }^{13} \mathrm{C}-\mathrm{NMR}\left(\mathrm{DMSO}-d_{6}\right): \delta 171.4,160.9,153.1,152.2,141.7,139.0$, 137.1, 129.8, 128.7, 107.9, 106.9, 99.9, $60.5\left(\mathrm{OCH}_{3}\right), 60.4\left(\mathrm{OCH}_{3}\right), 55.2\left(\mathrm{OCH}_{3}\right), 55.0\left(\mathrm{OCH}_{3}\right) . \mathrm{IR}: v_{\max }$ $(\mathrm{KBr}) \mathrm{cm}^{-1}: 3440.90,2938.31,1668.56,1580.98,1505.11,1413.46,1272.44,1240.40$. HRMS (EI): Found 405.1452 [M+ H] $]^{+}, \mathrm{C}_{21} \mathrm{H}_{25} \mathrm{O}_{8}$ requires 405.1471. 405.1549. 
(E)-3-(3-Hydroxyphenyl)-2-(3,4,5-trimethoxyphenyl)acrylic acid (1f). 3-Hydroxybenzaldehyde (377 mg, $3.09 \mathrm{mmol}), 3,4,5$-trimethoxyphenylacetic acid $(700 \mathrm{mg}, 3.09 \mathrm{mmol})$ were reacted following the general method B. Recrystallisation from methanol afforded the acrylic acid as fine yellow soild (711 mg, 60\%), m.p. $230-231{ }^{\circ} \mathrm{C} .{ }^{1} \mathrm{H}-\mathrm{NMR}$ (DMSO- $\left.d_{6}\right): \delta 7.61(\mathrm{~s}, 1 \mathrm{H}, \mathrm{C}=\mathrm{CH}), 7.05(\mathrm{t}, 1 \mathrm{H}, 8 \mathrm{~Hz}$, Ar-H), 6.67 (dd, 1H, 8 Hz, 1 Hz, Ar-H), 6.54-6.52 (m, 2H, Ar-H), 6.44 (s, 2H, Ar-H), 3.70 (s, 3H, $\left.\mathrm{O} \mathrm{CH}_{3}\right), 3.67\left(\mathrm{~s}, 6 \mathrm{H}, \mathrm{OCH}_{3}\right) .{ }^{13} \mathrm{C}-\mathrm{NMR}\left(\mathrm{DMSO}-d_{6}\right): \delta 168.40(\mathrm{COOH}), 157.02,152.93,139.05$, 136.96, 135.59, 132.96, 131.72, 129.19, 121.28, 116.85, 116.27, 106.74, $60.12\left(\mathrm{OCH}_{3}\right), 55.91\left(\mathrm{OCH}_{3}\right)$. IR: $v_{\max }(\mathrm{KBr}) \mathrm{cm}^{-1}:$ 3362.7, 2941.0, 2836.0, 2627.4, 1681.6, 1584.8, 1411.8, 1239.2, 1125.0, 997.3, 965.6, 688.2. HRMS (EI): Found $353.1003[\mathrm{M}+\mathrm{Na}]^{+}, \mathrm{C}_{18} \mathrm{H}_{18} \mathrm{O}_{6} \mathrm{Na}$ requires 353.1001. Hydrolysis of (E)-3-(3-acetoxyphenyl)-2-(3,4,5-trimethoxy-phenyl)acrylic acid 1k with $\mathrm{NAOH} / \mathrm{MeOH}$ for $12 \mathrm{~h}$ followed by acidification to $\mathrm{pH} 4$ afforded $1 \mathrm{f}$ in $88 \%$ yield.

(E)-3-(2,3,4-Trimethoxyphenyl)-2-(3,4,5-trimethoxyphenyl)acrylic acid (1h). 2,3,4-Trimethoxy-benzaldehyde $(607 \mathrm{mg}, 3.09 \mathrm{mmol})$ and 3,4,5-trimethoxyphenylacetic acid $(700 \mathrm{mg}, 3.09 \mathrm{mmol})$ were reacted following the general method B. Recrystallisation from methanol afforded the acrylic acid as fine yellow solid (374 mg, 30\%), m.p. $222-225{ }^{\circ} \mathrm{C} .{ }^{1} \mathrm{H}-\mathrm{NMR}$ (DMSO- $\left.d_{6}\right): \delta 7.91$ (s, $\left.1 \mathrm{H}, \mathrm{C}=\mathrm{CH}\right), 6.61$ (d, $\left.1 \mathrm{H}, 9 \mathrm{~Hz}, \mathrm{Ar}-\mathrm{H}\right)$, $6.46(\mathrm{~m}, 3 \mathrm{H}, \mathrm{Ar}-\mathrm{H}), 3.86\left(\mathrm{~s}, 3 \mathrm{H}, \mathrm{OCH}_{3}\right), 3.74\left(\mathrm{~s}, 6 \mathrm{H}, \mathrm{OCH}_{3}\right), 3.70\left(\mathrm{~s}, 3 \mathrm{H}, \mathrm{OCH}_{3}\right), 3.68\left(\mathrm{~s}, 6 \mathrm{H}, \mathrm{OCH}_{3}\right)$. ${ }^{13}$ C-NMR (DMSO- $d_{6}$ ): $\delta 168.96,154.79,153.48,153.36,141.88,137.35,133.34,132.05,124.97,121.23$, 108.20, 107.30, $61.95\left(\mathrm{OCH}_{3}\right), 60.88\left(\mathrm{OCH}_{3}\right), 60.58\left(\mathrm{OCH}_{3}\right), 56.40\left(\mathrm{OCH}_{3}\right), 56.31\left(\mathrm{OCH}_{3}\right) \mathrm{IR}: v_{\max }(\mathrm{KBr})$ $\mathrm{cm}^{-1}: 3440.90,2938.31,1668.56,1580.98,1505.11,1413.46,1272.44,1240.40$. HRMS (EI): Found 427.1370 $[\mathrm{M}+\mathrm{Na}]^{+}, \mathrm{C}_{21} \mathrm{H}_{24} \mathrm{O}_{8} \mathrm{Na}$ requires 427.1369.

(E)-3-(4-Hydroxy-3,5-dimethoxyphenyl)-2-(3,4,5-trimethoxyphenyl)acrylic acid (1j). 3,5-Dimethoxy-4hydroxybenzaldehyde (350 mg, $1.91 \mathrm{mmol})$ and 3,4,5-trimethoxyphenylacetic acid (433 mg, 1.91 mmol) were reacted following the general method B. Recrystallisation from methanol afforded the acrylic acid as pale yellow solid $(400 \mathrm{mg}, 48 \%)$, m.p. $212-214{ }^{\circ} \mathrm{C} .{ }^{1} \mathrm{H}-\mathrm{NMR}\left(\mathrm{CDCl}_{3}\right): \delta 7.86(\mathrm{~s}, 1 \mathrm{H}$, $\mathrm{C}=\mathrm{CH}), 6.52(\mathrm{~s}, 2 \mathrm{H}, \mathrm{Ar}-\mathrm{H}), 6.44(\mathrm{~s}, 2 \mathrm{H}, \mathrm{Ar}-\mathrm{H}), 3.86\left(\mathrm{~s}, 3 \mathrm{H}, \mathrm{OCH}_{3}\right), 3.83\left(\mathrm{~s}, 6 \mathrm{H}, \mathrm{OCH}_{3}\right), 3.59(\mathrm{~s}, 6 \mathrm{H}$, $\left.\mathrm{OCH}_{3}\right) .{ }^{13} \mathrm{C}-\mathrm{NMR}\left(\mathrm{CDCl}_{3}\right): \delta 171.94,168.05,153.40,151.32,141.59,137.23,131.51,130.88,130.35,139.41$, 107.34, 105.99, $60.34\left(\mathrm{OCH}_{3}\right), 55.77\left(\mathrm{OCH}_{3}\right), 55.37\left(\mathrm{OCH}_{3}\right), 19.97\left(\mathrm{CH}_{3}\right) . \mathrm{IR}: v_{\max }(\mathrm{KBr}) \mathrm{cm}^{-1}: 3438.9$, 2942.4, 1765.4, 1676.7, 1594.8, 1506.7, 1420.4, 1272.3, 1236.7, 1127.5, 999.8, 906.9. HRMS (EI): Found $455.1321[\mathrm{M}+\mathrm{Na}]^{+}, \mathrm{C}_{22} \mathrm{H}_{24} \mathrm{O}{ }_{9} \mathrm{Na}$ requires 455.1318 .

(E)-3-(3-Acetoxyphenyl)-2-(3,4,5-trimethoxyphenyl)acrylic acid (1k). 3-Hydroxybenzaldehyde (350 mg, 2.3 $\mathrm{mmol}$ ) and 3,4,5-trimethoxyphenylacetic acid $(520 \mathrm{mg}, 2.3 \mathrm{mmol})$ were reacted following the general method B. Recrystallisation from methanol afforded the acrylic acid as fine yellow solid ( $515 \mathrm{mg}, 56 \%)$, m.p. $176-180{ }^{\circ} \mathrm{C} .{ }^{1} \mathrm{H}-\mathrm{NMR}\left(\mathrm{CDCl}_{3}\right): \delta 7.88(\mathrm{~s}, 1 \mathrm{H}, \mathrm{C}=\mathrm{CH}), 6.95(\mathrm{~d}, 1 \mathrm{H}, 8 \mathrm{~Hz}, \mathrm{Ar}-\mathrm{H}), 6.88(\mathrm{dd}, 1 \mathrm{H}, 18 \mathrm{~Hz}$, $2 \mathrm{~Hz}, \mathrm{Ar}-\mathrm{H}), 6.65$ (s, 2H, Ar-H), 6.50 (s, 2H, Ar-H), 3.88 (s, 3H, OCH3), 3.81 (s, 6H, O CH3), 2.30 (s, 3H, COCH3). ${ }^{13} \mathrm{C}-\mathrm{NMR}\left(\mathrm{CDCl}_{3}\right): \delta 171.72,153.36,150.13,141.07,140.40,137.21,132.37,130.80,130.36$, 124.46, 122.28, 113.19, 105.96, 60.38 (OCH3), 55.72 (OCH3), 54.88 (OCH3), 20.18 (CH3). IR: vmax (KBr) $\mathrm{cm}^{-1}:$ 3362.7, 2941.0, 2836.0, 2627.4, 1681.6, 1584.8, 1411.8, 1239.2, 1125.0, 997.3, 965.6, 688.2. HRMS (EI): Found $395.1110[\mathrm{M}+\mathrm{H}]^{+}, \mathrm{C}_{20} \mathrm{H}_{20} \mathrm{O}_{7} \mathrm{Na}$ requires 395.1107.

(E)-2-(3,4,5-Trimethoxyphenyl)-3-(5-methylthiophen-2-yl)but-2-enoic acid (1p). 5-Methyl-2-thiophenecarboxaldehyde $(389 \mathrm{mg}, 0.337 \mathrm{~mL}, 3.09 \mathrm{mmol})$ and 3,4,5-trimethoxyphenylacetic acid $(700 \mathrm{mg}$, $2.3 \mathrm{mmol}$ ) were reacted following the general method B. Recrystallisation from methanol afforded the acrylic acid as a dark yellow solid ( $375 \mathrm{mg}, 36 \%$ ), m.p. $212-217^{\circ} \mathrm{C} .{ }^{1} \mathrm{H}-\mathrm{NMR}$ (DMSO- $\left.d_{6}\right): \delta 7.87(\mathrm{~s}, 1 \mathrm{H}$, $\mathrm{C}=\mathrm{CH}), 7.24(\mathrm{~d}, 1 \mathrm{H}, 3.6 \mathrm{~Hz}$, thiophene- $\mathrm{H}), 6.74(\mathrm{~d}, 1 \mathrm{H}, 3.6 \mathrm{~Hz}$, thiophene-H), $6.47(\mathrm{~s}, 2 \mathrm{H}, \mathrm{Ar}-\mathrm{H}), 3.72$ (s, 9H, OCH3), 2.31 (s, 3H, CH3). ${ }^{13} \mathrm{C}-\mathrm{NMR}$ (DMSO- $\left.d_{6}\right): \delta 15.23$ (CH3), 55.93 (OCH3), 60.20 (OCH3), 106.94, 125.42, 128.27, 130.99, 133.25, 134.85, 136.05, 137.44, 153.36, 168.10. IR: $v \max (\mathrm{KBr}) \mathrm{cm}^{-1}$ : 3426.13, 2998.75, 2537.61, 1662.03, 1581.35, 1412.40, 1283.72, 1128.23. HRMS (EI): Found 357.0763 $[\mathrm{M}+\mathrm{Na}]^{+}, \mathrm{C}_{17} \mathrm{H}_{18} \mathrm{O}_{5} \mathrm{NaS}$ requires 357.0773. 
(E)-3-(Furan-3-yl)-2-(3,4,5-trimethoxyphenyl)acrylic acid (1q). 3-Furaldehyde (296 mg, $0.26 \mathrm{~mL}, 3.09$ $\mathrm{mmol}$ ) and 3,4,5-trimethoxyphenylacetic acid (700 $\mathrm{mg}, 2.3 \mathrm{mmol}$ ) were reacted following the general method B. Recrystallisation from methanol afforded the acrylic acid as a dark brown solid (460 mg, 49\%), m.p. $188-191{ }^{\circ} \mathrm{C} .{ }^{1} \mathrm{H}-\mathrm{NMR}\left(\mathrm{DMSO}-d_{6}\right): 7.90$ (s, 1H, C=CH), $7.74(\mathrm{~s}, 1 \mathrm{H}, \mathrm{C}=\mathrm{CH}), 7.29-7.25(\mathrm{~m}, 1 \mathrm{H}$, $\mathrm{C}=\mathrm{CH}), 6.86(\mathrm{~m}, 1 \mathrm{H}, \mathrm{C}=\mathrm{CH}), 6.38(\mathrm{~s}, 2 \mathrm{H}, \mathrm{Ar}-\mathrm{H}), 3.92\left(\mathrm{~s}, 3 \mathrm{H}, \mathrm{OCH}_{3}\right), 3.81\left(\mathrm{~s}, 6 \mathrm{H}, \mathrm{OCH}_{3}\right) .{ }^{13} \mathrm{C}-\mathrm{NMR}$ (DMSO-d $\left.{ }_{6}\right)$ : 168.3, 153.0, 143.7, 143.6, 139.0, 138.4, 138.0, 124.4, 108.2, 105.1, $60.8\left(\mathrm{OCH}_{3}\right), 56.1\left(\mathrm{OCH}_{3}\right)$. IR: $v_{\max }(\mathrm{KBr}) \mathrm{cm}^{-1}: 3447.5,2938.9,2627.6,1674.9,1582.2,1504.8,1909.5,1504.8,1909.5,1236.5,1127.5$, 1007.9, 803.2. HRMS (EI): Found 327.0839 [M + Na $]^{+}, \mathrm{C}_{16} \mathrm{H}_{16} \mathrm{O}_{6} \mathrm{Na}$ requires 327.0845.

(E)-3-(3-Methoxy-4-hydroxyphenyl)-2-(3,4,5-trimethoxyphenyl)acrylic acid (1r). 4-Hydroxy-3-methoxybenzaldehyde $(470 \mathrm{mg}, 3.09 \mathrm{mmol})$ and 3,4,5-trimethoxyphenylacetic acid (700 mg, $3.09 \mathrm{mmol})$ were reacted following the general method $\mathrm{B}$. Recrystallisation from methanol afforded the acrylic acid as fine yellow needles (923 mg, 83\%), m.p. $237-239{ }^{\circ} \mathrm{C} .{ }^{1} \mathrm{H}-\mathrm{NMR}$ (DMSO-d $): 12.45$ (br s, 1H, COOH), 8.98 (br s, 1H, OH), 7.57 (s, 1H, C=CH), 6.81 (d, J = $7 \mathrm{~Hz}, 1 \mathrm{H}, \mathrm{Ar}-\mathrm{H}), 6.60$ (d, J = $7 \mathrm{~Hz}, 1 \mathrm{H}, \mathrm{Ar}-\mathrm{H}), 6.53$ (s, 1H, Ar-H), 6.44 (s, 2H, Ar-H), $3.73\left(\mathrm{~s}, 3 \mathrm{H}, \mathrm{OCH}_{3}\right), 3.71\left(\mathrm{~s}, 3 \mathrm{H}, \mathrm{OCH}_{3}\right), 3.69\left(\mathrm{~s}, 6 \mathrm{H}, \mathrm{OCH}_{3}\right) .{ }^{13} \mathrm{C}-\mathrm{NMR}$ (DMSO- $\left.d_{6}\right): 168.61(\mathrm{COOH}), 153.09,148.89,145.84,139.13,136.90,132.18,130.31,127.02,122.99,117.19$, $111.49,106.65,60.12\left(\mathrm{OCH}_{3}\right), 55.91\left(\mathrm{OCH}_{3}\right), 55.45\left(\mathrm{OCH}_{3}\right) . \mathrm{IR}: v_{\max }(\mathrm{KBr}) \mathrm{cm}^{-1}: 3423.9$ (br), 2939.8 , 1671.3, 1585.2, 1509.6, 1455.3, 1411.1, 1268.3, 1239.3, 1126.2. HRMS (EI): Found 383.1103 [M + Na] ${ }^{+}$, $\mathrm{C}_{19} \mathrm{H}_{20} \mathrm{O}_{7} \mathrm{Na}$ requires 383.1107 .

(4-((E/Z)-1-(4-(2-Methylaminoethoxy)phenyl)-2-phenylbut-1-enyl)phenoxy)(tert-butyl)dimethylsilane (2a). (4-((E/Z)-1-(4-(2-Bromoethoxy)phenyl)-2-phenylbut-1-enyl)phenoxy)(tert-butyl) dimethylsilane $(1.457 \mathrm{~g}, 2.69 \mathrm{mmol})$ was dissolved in a solution $(2 \mathrm{M})$ of methylamine in THF $(1.678 \mathrm{~g}, 26.99 \mathrm{~mL}$, $54 \mathrm{mmol})$. The reaction mixture was stirred in a sealed pressure tube for $48 \mathrm{~h}$ at $60{ }^{\circ} \mathrm{C}$, followed by the addition of dichloromethane $(100 \mathrm{~mL})$. The organic phase was washed with a sodium bicarbonate/sodium carbonate $(\mathrm{pH} 10),(50 \mathrm{~mL})$. The aqueous phase was then extracted with $3 \times 50 \mathrm{~mL}$ dichloromethane. The organic layers were combined, dried over sodium sulfate and concentrated in vacuo to yield crude product. The material was purified via flash chromatography on silica gel (DCM:EtOAc 3:1) to afford the product as a brown resin. $(1.24 \mathrm{~g}, 94 \%)$. ${ }^{1} \mathrm{H}-\mathrm{NMR}\left(\mathrm{CDCl}_{3}\right): \delta$ 7.20-6.50 (m, 26H, Ar-H), $4.11\left(\mathrm{t}, 0.43 \times 4 \mathrm{H}, J=5.0 \mathrm{~Hz}, \mathrm{CH}_{2}\right), 3.95\left(\mathrm{t}, 0.43 \times 4 \mathrm{H}, \mathrm{J}=5.0 \mathrm{~Hz}, \mathrm{CH}_{2}\right), 3.36$ (s, 2H, NH), $2.99\left(\mathrm{~s}, 0.57 \times 4 \mathrm{H}, \mathrm{CH}_{2}\right), 2.89\left(\mathrm{~s}, 0.43 \times 4 \mathrm{H}, \mathrm{CH}_{2}\right) 2.53\left(\mathrm{~m}, 10 \mathrm{H}, \mathrm{NCH}_{3}, \mathrm{CH}_{2}\right), 1.01-0.92(\mathrm{~m}$, $\left.24 \mathrm{H}, \mathrm{CH}_{3},\left(\mathrm{CH}_{3}\right)_{3}\right), 0.26\left(\mathrm{~s}, 0.43 \times 12 \mathrm{H}, \mathrm{Si}\left(\mathrm{CH}_{3}\right)_{2}\right), 0.13\left(\mathrm{~s}, 0.57 \times 12 \mathrm{H}, \mathrm{Si}\left(\mathrm{CH}_{3}\right)_{2}\right) .{ }^{13} \mathrm{C}-\mathrm{NMR}\left(\mathrm{CDCl}_{3}\right): \delta$ 156.94, 156.10, 153.84, 153.06, 142.19, 142.11, 140.65, 140.59, 137.53, 137.44, 136.35, 136.06, 136.02, 135.68, $131.57,131.43,130.20,130.12,129.25,127.41,127.33,125.48,125.44,119.12,118.54,113.54,112.80,65.99$, 65.73, 50.12, 50.03, 49.47, 35.39, 35.26, 28.60, 28.47, 25.26, 25.24, 17.75, 13.24, 13.21, -4.80, -4.91. IR: $v_{\max }(\mathrm{KBr}) \mathrm{cm}^{-1}:$ 3431.2, 1606.0, 1508.0, 1241.3, 1173.2, 1099.5, 1078.8, 1036.9, 938.9, 846.8. HRMS (EI): Found $488.3088[\mathrm{M}+\mathrm{H}]^{+}, \mathrm{C}_{31} \mathrm{H}_{41} \mathrm{NO}_{2} \mathrm{Si}$ requires 488.2907.

\{2-[4-(1,2-Diphenylbut-1-enyl)phenoxy]ethyl\}methylamine (2b) \{2-[4-(1,2-Diphenylbut-1-enyl)phenoxy]ethyl bromide $(0.41 \mathrm{~g}, 1.00 \mathrm{mmol})$ was dissolved in anhydrous tetrahydrofuran $(20 \mathrm{~mL})$ together with methylamine (in a 20 molar equivalent excess), and sealed in a high pressure tube. The reaction was heated to $60{ }^{\circ} \mathrm{C}$ while stirring for 48-72 h. Following addition of sodium carbonate/sodium hydrogen carbonate $\mathrm{pH} 10$ buffer solution $(50 \mathrm{~mL})$, the mixture were extracted with DCM $(3 \times 50 \mathrm{~mL})$. The organic phases were combined, dried over sodium sulfate and the solvent evaporated in vacuo to afford a crude product which was then purified via flash chromatography (DCM:MeOH) to afford the product as a brown oil $(0.28 \mathrm{~g}, 77 \%, E / \mathrm{Z}=1: 1.1) .{ }^{1} \mathrm{H}-\mathrm{NMR}\left(\mathrm{CDCl}_{3}\right): \delta 0.96-1.02\left(\mathrm{~m}, 6 \mathrm{H}, \mathrm{CH}_{3}\right), 2.49-2.58$ $\left(\mathrm{m}, 10 \mathrm{H}, \mathrm{CH}_{2}, \mathrm{CH}_{3}\right), 2.98-3.08\left(\mathrm{~m}, 4 \mathrm{H}, \mathrm{CH}_{2} \mathrm{~N}\right), 3.99-4.23\left(\mathrm{~m}, 6 \mathrm{H}, \mathrm{NH}, \mathrm{CH}_{2} \mathrm{O}\right), 6.59-7.40(\mathrm{~m}, 28 \mathrm{H}, \mathrm{ArH})$. ${ }^{13} \mathrm{C}-\mathrm{NMR}\left(\mathrm{CDCl}_{3}\right)$ : 13.25, 28.62, 28.64, 35.16, 35.28, 49.76, 49.89, 65.45, 65.78, 112.96, 113.70, 125.28, $125.67,126.17,126.92,127.39,127.50,127.72,129.03,129.28,130.23,130.40,131.53,135.44,135.94,137.74$, $137.89,141.03,141.56,141.89,142.88,143.33,156.06,156.92$. IR: $v_{\max }(\mathrm{KBr}) \mathrm{cm}^{-1}: 3431.2,1606.0,1508.0$, 1241.3, 1173.2, 1099.5, 1078.8, 1036.9, 938.9, 846.8. HRMS (EI): Found 358.2173 [M + H] ${ }^{+}, \mathrm{C}_{25} \mathrm{H}_{28} \mathrm{NO}$ requires 358.2171 . 


\subsubsection{General Method for the Synthesis of Endoxifen-Acrylic Acid Conjugates 3a-3m}

Step (i): A mixture of the required acrylic acid (1 eq., $0.154 \mathrm{mmol})$, DCC (1 eq., $0.154 \mathrm{mmol}, 32 \mathrm{mg}$ ), and HOBt (1 eq., $0.154 \mathrm{mmol}, 21 \mathrm{mg}$ ) was suspended in $3 \mathrm{~mL}$ of anhydrous DCM and stirred for $10 \mathrm{~min}$ under a nitrogen atmosphere. The endoxifen derivative $\mathbf{2 a}$ (75 mg, 1 eq., $0.154 \mathrm{mmol})$ was dissolved in $3 \mathrm{~mL}$ of anhydrous DCM and slowly added to the mixture via syringe. Reaction was allowed stir for 24-48 h. Reaction was monitored via TLC. The reaction mixture was diluted to $15 \mathrm{~mL}$ with anhydrous DCM and filtered to remove DCU. The filtrate was evaporated to dryness under reduced pressure. Purification was not required at this step. Silyl deprotection: The residue was dissolved in THF ( $3 \mathrm{~mL})$ and stirred under nitrogen. A solution of $0.1 \mathrm{M}$ TBAF (2 eq.) was added to the mixture and allowed to stir for $24 \mathrm{~h}$. The mixture was evaporated to dryness under reduced pressure. The residue was dissolved in DCM and was washed with $10 \% \mathrm{HCl}$ solution. The resulting organic phase was dried over sodium sulphate and evaporated to dryness under vacuum. The material was purified via flash chromatography on silica gel.

Step (ii): A mixture of the required acrylic acid (1.2 eq.), EDC (1.4 eq.), and HOBt (1.4 eq.) was suspended in anhydrous dichloromethane $(3 \mathrm{~mL})$ and stirred for 10 min under a nitrogen atmosphere. The endoxifen derivative $\mathbf{2 a}$ (1 eq.) was dissolved in anhydrous dichloromethane ( $3 \mathrm{~mL})$ and slowly added to the mixture via syringe. Reaction was allowed stir for $16 \mathrm{~h}$. Reaction was monitored via TLC. The reaction mixture was diluted to $15 \mathrm{~mL}$ with anhydrous dichloromethane. To this mixture, water $(20 \mathrm{~mL})$ was added. The aqueous phase was extracted with DCM $(20 \mathrm{~mL} \times 3)$, brine $(50 \mathrm{~mL})$, dried over $\mathrm{Na}_{2} \mathrm{SO}_{4}$ and evaporated to dryness in vacuo to yield the crude product. The material was purified via flash chromatography on silica gel. (DCM:EtOAc). The silyl deprotection was performed as above.

(E/Z)-3-(Benzo[d][1,3]dioxol-5-yl)-N-(2-(4-((Z)-1-(4-hydroxyphenyl)-2-phenylbut-1-en-1-yl)phenoxy)ethyl)-2(4-methoxyphenyl)-N-methylacrylamide (3k). Following the general method above, the acrylic acid $1 \mathrm{~m}$ (1.2 eq., $176 \mathrm{mg}, 0.492 \mathrm{mmol})$, EDC (1.4 eq., $110 \mathrm{mg}, 0.572 \mathrm{mmol})$ and HOBt (1.4 eq., $77.6 \mathrm{mg}$, $0.572 \mathrm{mmol}$ ) was reacted with endoxifen derivative (1 eq., $200 \mathrm{mg}, 0.41 \mathrm{mmol}$ ). Purification by flash chromatography over silica gel (DCM:EtOAc, gradient 20:1 to 10:1) afforded the silyl ether as a white solid (261 mg, 83\%). HRMS: Found 790.3566 [M + Na] ${ }^{+}, \mathrm{C}_{48} \mathrm{H}_{53} \mathrm{NO}_{6} \mathrm{NaSi}$ requires 790.3540. The protected compound (142 $\mathrm{mg}, 0.185 \mathrm{mmol})$ was dissolved in THF ( $3 \mathrm{~mL})$ and stirred under nitrogen. A solution of TBAF (1M in THF, 1 eq., $0.185 \mathrm{~mL}, 0.185 \mathrm{mmol}$ ) was added to the mixture and allowed to stir for $1 \mathrm{~h}$. The mixture was evaporated to dryness under reduced pressure and purified via flash chromatography over silica gel (DCM:EtOAc, gradient 6:1 to 3:1) to afford the product as a white solid (109 mg, 91\%), m.p. 84-86 ${ }^{\circ} \mathrm{C} .{ }^{1} \mathrm{H}-\mathrm{NMR}\left(\mathrm{CDCl}_{3}\right) \delta 6.99-7.24(\mathrm{~m}, 17 \mathrm{H}, \mathrm{Ar}-\mathrm{H}, \mathrm{C}=\mathrm{CH})$, 6.34-6.88 (m, 25H, Ar-H), $5.87\left(\mathrm{~s}, 4 \mathrm{H}, \mathrm{CH}_{2}\right), 4.00-4.26\left(\mathrm{~m}, 4 \mathrm{H}, \mathrm{CH}_{2}\right), 3.59-3.86\left(\mathrm{~m}, 10 \mathrm{H}, \mathrm{OCH}_{3}, \mathrm{CH}_{2}\right)$, 2.96-3.13 (m, 6H, NCH$), 2.38-2.54\left(\mathrm{~m}, 4 \mathrm{H}, \mathrm{CH}_{2}\right), 0.87-0.96\left(\mathrm{~m}, 6 \mathrm{H}, \mathrm{CH}_{3}\right) .{ }^{13} \mathrm{C}-\mathrm{NMR}\left(\mathrm{CDCl}_{3}\right) \delta 172.8$ (C=O), 160.7, 159.3, 158.3, 154.9, 154.0, 148.0, 147.3, 147.3, 147.2, 147.1, 142.6, 140.9, 137.8, 135.7, 135.4, 131.98, 131.96, 130.6, 130.3, 130.2, 130.1, 129.7, 129.7, 129.5, 127.81, 127.8, 125.9, 124.0, 115.1, 114.4, 114.2, 113.9, 113.2, 109.1, 108.1, 108.1, 101.0, $100.2\left(\mathrm{OCH}_{2} \mathrm{O}\right), 65.9\left(\mathrm{CH}_{2}\right), 60.4\left(\mathrm{CH}_{2}\right), 55.2\left(\mathrm{OCH}_{3}\right), 47.6\left(\mathrm{CH}_{2}\right)$, $38.7\left(\mathrm{NCH}_{3}\right), 25.6\left(\mathrm{CH}_{2}\right), 13.6\left(\mathrm{CH}_{3}\right)$. IR: $v_{\max }(\mathrm{KBr}) \mathrm{cm}^{-1}: 3239.3,2929.9,1735.6,1605.7,1508.4,1244.2$, 1036.7, 835.5 HRMS (EI): Found 676.2685 [M + Na] ${ }^{+}, \mathrm{C}_{42} \mathrm{H}_{39} \mathrm{NO}_{6} \mathrm{Na}$ requires 676.2675.

(E/Z)-N-(2-(4-((E)-1-(4-Hydroxyphenyl)-2-phenylbut-1-en-1-yl)phenoxy)ethyl)-3-(4-methoxy-3-nitro-phenyl)$N$-methyl-2-(3,4,5-trimethoxyphenyl)acrylamide (3a). Following the general method above, the acrylic acid $1 \mathrm{a}$ (1.2 eq., $191 \mathrm{mg}, 0.492 \mathrm{mmol})$, EDC (1.4 eq., $110 \mathrm{mg}, 0.572 \mathrm{mmol})$, and HOBt (1.4 eq., $77.6 \mathrm{mg}$, $0.572 \mathrm{mmol}$ ) was reacted with endoxifen derivative $2 \mathrm{a}$ (1 eq., $200 \mathrm{mg}, 0.41 \mathrm{mmol}$ ). The crude product was afforded as a brown resin. The material was purified via flash chromatography over silica gel (DCM:EtOAc, gradient 20:1 to 10:1) to afford the product as a white solid. (309 $\mathrm{mg}, 88 \%$ ), HRMS: Found $881.3841[\mathrm{M}+\mathrm{Na}]^{+}, \mathrm{C}_{50} \mathrm{H}_{58} \mathrm{~N}_{2} \mathrm{O}_{9} \mathrm{NaSi}$ requires 881.3809. The product was then deprotected. The protected compound (182 $\mathrm{mg}, 0.212 \mathrm{mmol}$ ) was dissolved in $3 \mathrm{~mL}$ THF and stirred under nitrogen environment. A solution of TBAF (1M in THF, 1 eq., $0.212 \mathrm{~mL}, 0.212 \mathrm{mmol}$ ) was added to the mixture 
and allowed to stir for $1 \mathrm{~h}$. The mixture was evaporated to dryness under reduced pressure. The material was purified via flash chromatography over silica gel (DCM:EtOAc, gradient 6:1 to 3:1) to afford the product as a white solid. $(146 \mathrm{mg}, 93 \%)$, m.p. $77-78{ }^{\circ} \mathrm{C} .{ }^{1} \mathrm{H}-\mathrm{NMR}\left(\mathrm{CDCl}_{3}\right) \delta 7.58-7.73(\mathrm{~m}, 2 \mathrm{H}$, Ar-H), 6.99-7.17 (m, 12H, Ar-H, C=CH), 6.09-6.88 (m, 24H, Ar-H), 4.01-4.28 (m, 4H, $\left.\mathrm{CH}_{2}\right), 3.53-3.93$ $\left(\mathrm{m}, 28 \mathrm{H}, \mathrm{CH}_{2}, \mathrm{OCH}_{3}\right), 2.99-3.20\left(\mathrm{~m}, 6 \mathrm{H}, \mathrm{NCH}_{3}\right), 2.36-2.50\left(\mathrm{~m}, 4 \mathrm{H}, \mathrm{CH}_{2}\right), 0.84-0.96\left(\mathrm{~m}, 6 \mathrm{H}, \mathrm{CH}_{3}\right)$. ${ }^{13} \mathrm{C}-\mathrm{NMR}\left(\mathrm{CDCl}_{3}\right): \delta 172.8(\mathrm{C}=\mathrm{O}), 172.7(\mathrm{C}=\mathrm{O}), 157.2,156.3,155.9,155.1,154.1,153.2,142.7,142.6,141.2$, 141.1, 140.9, 137.8, 137.7, 137.1, 136.7, 136.3, 135.7, 135.3, 132.1, 132.0, 130.8, 130.7, 129.7, 127.8, 125.9, 115.1, 114.4, 113.9, 113.1, 113.1, 105.3, 105.3, 66.7, 66.4, 65.1, 64.8, 60.9, 60.5, 56.1, 49.2, 48.3, 48.2, 37.7, 37.6, 35.7, 35.7, 35.2, 35.1, 34.2, 34.1, 32.1, 32.0, 31.6, 31.6, 29.1, $29.0\left(\mathrm{CH}_{2}\right), 13.7\left(\mathrm{CH}_{3}\right)$. IR: $v_{\max }(\mathrm{KBr})$ $\mathrm{cm}^{-1}: 3240.6,2933.8,1733.9,1606.5,1505.9,1238.4,1126.7,834.2$. HRMS (EI): Found 743.2974 [M $\mathrm{H}]^{-}, \mathrm{C}_{44} \mathrm{H}_{43} \mathrm{~N}_{2} \mathrm{O}_{9}$ requires 743.2969.

(E/Z)-2-(3,5-Dimethoxyphenyl)-N-(2-(4-((Z)-1-(4-hydroxyphenyl)-2-phenylbut-1-en-1-yl)phenoxy)ethyl)N-methyl-3-(3,4,5-trimethoxyphenyl)acrylamide (3b). Following the general method above, the acrylic acid analogue $\mathbf{1 b}$ was reacted with endoxifen derivative $\mathbf{2 a}$. The final product was purified via flash chromatography over silica gel (DCM:EtOAc, gradient 6:1 to 3:1) to afford the product as a brown resin $(33 \%) .{ }^{1} \mathrm{H}-\mathrm{NMR}\left(\mathrm{CDCl}_{3}\right): \delta 7.17-6.37(\mathrm{~m}, 38 \mathrm{H}, \mathrm{Ar}-\mathrm{H}, \mathrm{C}=\mathrm{CH}), 4.25-4.09\left(\mathrm{~m}, 38 \mathrm{H}, \mathrm{OCH}_{3}, \mathrm{NCH}_{2}\right.$, $\left.\mathrm{OCH}_{2}\right), 3.23-3.05\left(\mathrm{~m}, 6 \mathrm{H}, \mathrm{NCH}_{3}\right), 2.52-2.48\left(\mathrm{~m}, 4 \mathrm{H}, \mathrm{CH}_{2}\right), 0.94-0.91\left(\mathrm{~m}, 6 \mathrm{H}, \mathrm{CH}_{3}\right),{ }^{13} \mathrm{C}-\mathrm{NMR}\left(\mathrm{CDCl}_{3}\right)$ : $\delta$ 160.56, 154.86, 153.90, 152.22, 152.20, 140.38, 137.34, 137.30, 131.56, 131.52, 130.20, 130.13, 129.97, $129.23,127.38,125.44,114.67,113.95,113.47,112.71,106.28,106.25,100.06,60.45\left(\mathrm{OCH}_{3}\right), 55.34\left(\mathrm{OCH}_{3}\right)$, $54.94\left(\mathrm{OCH}_{3}\right), 53.01,48.70\left(\mathrm{NCH}_{3}\right), 33.41\left(\mathrm{CH}_{2}\right), 28.63\left(\mathrm{CH}_{2}\right), 28.54\left(\mathrm{CH}_{2}\right), 25.10\left(\mathrm{CH}_{2}\right), 24.45\left(\mathrm{CH}_{2}\right)$, 13.22 $\left(\mathrm{CH}_{3}\right), 13.17\left(\mathrm{CH}_{3}\right)$ IR: $v_{\max }(\mathrm{KBr}) \mathrm{cm}^{-1}: 3167.5,2935.3,1737.4,1581.6,1505.6,1233.1,1125.0$, 1003.7 834.9 HRMS (EI): Found $752.3223[\mathrm{M}+\mathrm{Na}]^{+}, \mathrm{C}_{45} \mathrm{H}_{47} \mathrm{NO}_{8} \mathrm{Na}$ requires 752.3199.

(E/Z)-N-(2-(4-((Z)-1-(4-Hydroxyphenyl)-2-phenylbut-1-en-1-yl)phenoxy)ethyl)-N-methyl-2,3-bis(3,4,5trimethoxyphenyl)acrylamide (3c). Following the general method above, the acrylic acid 1c (1.2 eq., $198 \mathrm{mg}, 0.492 \mathrm{mmol}$ ), EDC (1.4 eq., $110 \mathrm{mg}, 0.572 \mathrm{mmol}$ ), and HOBt (1.4 eq., $77.6 \mathrm{mg}, 0.572 \mathrm{mmol}$ ) was reacted with endoxifen derivative $2 \mathbf{a}$ ( 1 eq., $200 \mathrm{mg}, 0.41 \mathrm{mmol}$ ) to afford the silyl ether which was purified via flash chromatography over silica gel (DCM:EtOAc, gradient 20:1 to 10:1) to afford a white solid. (315 mg, 88\%). HRMS: Found $898.4193\left[\mathrm{M}+\mathrm{H}^{+}, \mathrm{C}_{52} \mathrm{H}_{63} \mathrm{NO}_{9} \mathrm{NaSi}\right.$ requires 896.4170. The protected compound ( $158 \mathrm{mg}, 0.18 \mathrm{mmol}$ ) was dissolved in $3 \mathrm{~mL}$ THF and treated with a solution of TBAF ( $1 \mathrm{M}$ in THF, 1 eq., $0.18 \mathrm{~mL}, 0.18 \mathrm{mmol}$ ) was added to the mixture and allowed to stir for $1 \mathrm{~h}$. Purifiication by flash chromatography over silica gel (DCM:EtOAc, gradient 6:1 to 3:1) afforded the product as a white solid. $(128 \mathrm{mg}, 94 \%), \mathrm{m} . \mathrm{p} .77-78{ }^{\circ} \mathrm{C} .{ }^{1} \mathrm{H}-\mathrm{NMR}\left(\mathrm{CDCl}_{3}\right) \delta 6.97-7.19(\mathrm{~m}, 14 \mathrm{H}, \mathrm{Ar}-\mathrm{H}$, $\mathrm{C}=\mathrm{CH}), 6.30-6.89(\mathrm{~m}, 24 \mathrm{H}, \mathrm{Ar}-\mathrm{H}), 4.02-4.27\left(\mathrm{~m}, 4 \mathrm{H}, \mathrm{CH}_{2}\right), 3.52-3.95\left(\mathrm{~m}, 40 \mathrm{H}, \mathrm{OCH}_{3}\right), 2.98-3.29(\mathrm{~m}$, $\left.6 \mathrm{H}, \mathrm{NCH}_{3}\right), 2.37-2.53\left(\mathrm{~m}, 4 \mathrm{H}, \mathrm{CH}_{2}\right), 0.83-0.96\left(\mathrm{~m}, 6 \mathrm{H}, \mathrm{CH}_{3}\right),{ }^{13} \mathrm{C}-\mathrm{NMR}\left(\mathrm{CDCl}_{3}\right), \delta 171.3(\mathrm{C}=\mathrm{O}), 155.0$, 154.1, 153.4, 152.7, 152.7, 142.6, 142.5, 141.0, 137.8, 137.8, 137.6, 136.6, 135.6, 135.2, 132.0, 131.9, 130.6, 130.6, 130.5, 129.6, 129.6, 127.8, 125.9, 115.0, 114.3, 113.9, 113.1, 106.7, 106.6, 106.1, 106.1, 60.9, 60.82 $\left(\mathrm{OCH}_{3}\right), 60.81\left(\mathrm{OCH}_{3}\right), 60.4\left(\mathrm{OCH}_{3}\right), 56.1\left(\mathrm{OCH}_{3}\right), 55.8\left(\mathrm{OCH}_{3}\right), 53.4,47.7,39.0\left(\mathrm{NCH}_{3}\right) 29.1\left(\mathrm{CH}_{2}\right)$, $29.0\left(\mathrm{CH}_{2}\right), 13.6\left(\mathrm{CH}_{3}\right), 13.56\left(\mathrm{CH}_{3}\right)$ IR: $v_{\max }(\mathrm{KBr}) \mathrm{cm}^{-1}: 3167.5,2935.3,1737.4,1581.6,1505.6,1233.1$, 1125.0, 1003.7 834.9. HRMS (EI): Found 782.3301 [M + Na] $]^{+}, \mathrm{C}_{46} \mathrm{H}_{49} \mathrm{NO}_{9} \mathrm{Na}$ requires 782.3305.

(E/Z)-2-(3,5-Dimethoxyphenyl)-3-(3-hydroxy-4-methoxyphenyl)-N-(2-(4-((Z)-1-(4-hydroxyphenyl)-2-phenylbut1-en-1-yl)phenoxy)ethyl)-N-methylacrylamide (3d). Following the general method above, the acrylic acid analogue $\mathbf{1 d}$ was reacted with endoxifen derivative 2a. Following deprotection, the final product was purified via flash chromatography over silica gel (DCM:EtOAc, gradient 6:1 to 3:1) to afford the product as a brown resin (54\%). ${ }^{1} \mathrm{H}-\mathrm{NMR}\left(\mathrm{CDCl}_{3}\right): \delta 7.19-6.37(\mathrm{~m}, 40 \mathrm{H}, \mathrm{Ar}-\mathrm{H}, \mathrm{C}=\mathrm{CH}), 4.24-3.60(\mathrm{~m}$, $\left.26 \mathrm{H}, \mathrm{OCH}_{3}, \mathrm{O}_{-} \mathrm{CH}_{2}, \mathrm{~N}-\mathrm{CH}_{2}\right), 3.18-3.04\left(\mathrm{~m}, 6 \mathrm{H}, \mathrm{NCH}_{3}\right), 2.53-2.47\left(\mathrm{~m}, 4 \mathrm{H}, \mathrm{CH}_{2}\right), 0.95-0.91\left(\mathrm{~m}, 6 \mathrm{H}, \mathrm{CH}_{3}\right)$. ${ }^{13} \mathrm{C}-\mathrm{NMR}\left(\mathrm{CDCl}_{3}\right): \delta 160.44(\mathrm{C}=\mathrm{O}), 156.55,154.65,153.69,146.00,145.98,144.60,144.58,142.17,140.49$, $140.38,137.38,135.30,135.15,131.56,130.18,129.25,127.98,127.38,127.35,125.44,121.62,115.01,114.63$, $113.90,113.48,112.74,109.71,106.29,100.13,55.40\left(\mathrm{OCH}_{3}\right), 54.89\left(\mathrm{OCH}_{3}\right), 53.00\left(\mathrm{CH}_{2}\right), 48.75\left(\mathrm{NCH}_{3}\right)$, $33.41\left(\mathrm{OCH}_{2}\right), 28.61\left(\mathrm{CH}_{2} \mathrm{CH}_{3}\right), 28.55\left(\mathrm{CH}_{2} \mathrm{CH}_{3}\right), 25.11\left(\mathrm{CH}_{2}\right), 24.45\left(\mathrm{CH}_{2}\right), 13.21\left(\mathrm{CH}_{3}\right), 13.18\left(\mathrm{CH}_{3}\right)$. 
IR: $v_{\max }(\mathrm{KBr}) \mathrm{cm}^{-1}: 3379.5,2933.2,1735.1,1606.3,1581.7,1505.9,1238.9,1124.6,1026.5,833.4$. HRMS (EI): Found $708.2925[\mathrm{M}+\mathrm{Na}]^{+}, \mathrm{C}_{43} \mathrm{H}_{43} \mathrm{NO}_{7} \mathrm{Na}$ requires 708.2937.

(E/Z)-3-(3,4-Dihydroxyphenyl)-N-(2-(4-((Z)-1-(4-hydroxyphenyl)-2-phenylbut-1-en-1-yl)phenoxy)ethyl)-Nmethyl-2-(3,4,5-trimethoxyphenyl)acrylamide (3e). Following the general method above, the acrylic acid 1e (1.2 eq., $170 \mathrm{mg}, 0.492 \mathrm{mmol})$, EDC (1.4 eq., $110 \mathrm{mg}, 0.572 \mathrm{mmol})$, and HOBt (1.4 eq., $77.6 \mathrm{mg}, 0.572$ $\mathrm{mmol}$ ) was reacted with endoxifen derivative $2 \mathrm{a}$ (1 eq., $200 \mathrm{mg}, 0.41 \mathrm{mmol})$ to afford the silyl ether as a which was purified via flash chromatography over silica gel (DCM:EtOAc, gradient 20:1 to 10:1) to afford a white solid. (237 mg, 71\%). HRMS: Found $838.3751[\mathrm{M}+\mathrm{Na}]^{+}, \mathrm{C}_{49} \mathrm{H}_{57} \mathrm{NO}_{8} \mathrm{NaSi}$ requires 838.3751. The silyl ether ( $157 \mathrm{mg}, 0.192 \mathrm{mmol})$ was dissolved in $3 \mathrm{~mL}$ THF and stirred under nitrogen environment. A solution of TBAF (1 M in THF, 1 eq., $0.192 \mathrm{~mL}, 0.192 \mathrm{mmol}$ ) was added to the mixture and allowed to stir for $1 \mathrm{~h}$. The mixture was evaporated to dryness under reduced pressure. The material was purified via flash chromatography over silica gel to afford the product as a white solid. (113 mg, 84\%), m.p. 63-69 ${ }^{\circ} \mathrm{C} .{ }^{1} \mathrm{H}-\mathrm{NMR}\left(\mathrm{CDCl}_{3}\right): \delta 7.13-6.49(\mathrm{~m}, 38 \mathrm{H}, \mathrm{Ar}-\mathrm{H}, \mathrm{C}=\mathrm{CH}), 4.22-3.52(\mathrm{~m}$,

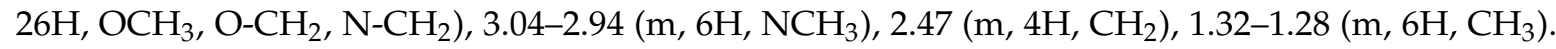
${ }^{13} \mathrm{C}-\mathrm{NMR}\left(\mathrm{CDCl}_{3}\right): \delta 156.62,154.66,153.66,152.88,145.98,145.96,144.60,142.12,137.33,135.20,132.01$, $131.54,130.22,130.10,129.58,129.25,128.00,127.32,127.30,125.46,121.50,115.10,114.64,114.05,113.40$, $112.65,109.76,105.58,65.71,55.57,55.44,48.72,33.44,28.62,25.31,24.54,13.22,13.17$. IR: $v_{\max }(\mathrm{KBr})$ $\mathrm{cm}^{-1}: 3250.6,2930.1,1735.4,1605.6,1605.1,1244.1,1037.1,835.6$ HRMS (EI): Found 724.2881 [M + Na] $]^{+}$, $\mathrm{C}_{43} \mathrm{H}_{43} \mathrm{NO}_{8} \mathrm{Na}$ requires 724.2886 .

(E/Z)-3-(3-Hydroxyphenyl)-N-(2-(4-((Z)-1-(4-hydroxyphenyl)-2-phenylbut-1-en-1-yl)phenoxy)ethyl)-N-methyl2-(3,4,5-trimethoxyphenyl)acrylamide (3f). Following the general method above, the acrylic acid analogue If was reacted with endoxifen derivative $\mathbf{2} \mathbf{a}$. The product was purified by flash chromatography over silica gel (DCM:EtOAc, gradient 6:1 to 3:1) to afford the product as a brown resin (45\%). ${ }^{1} \mathrm{H}-\mathrm{NMR}$ $\left(\mathrm{CDCl}_{3}\right): \delta 7.15-6.38(\mathrm{~m}, 40 \mathrm{H}, \mathrm{Ar}-\mathrm{H}, \mathrm{C}=\mathrm{CH}), 4.27-3.45\left(\mathrm{~m}, 26 \mathrm{H}, \mathrm{OCH}_{3}, \mathrm{~N}-\mathrm{CH}_{2}, \mathrm{O}-\mathrm{CH}_{2}\right), 3.26-3.07$ $\left(\mathrm{m}, 6 \mathrm{H}, \mathrm{NCH}_{3}\right), 2.49-2.47\left(\mathrm{~m}, 4 \mathrm{H}, \mathrm{CH}_{2}\right), 0.94-0.91\left(\mathrm{~m}, 6 \mathrm{H}, \mathrm{CH}_{3}\right){ }^{13} \mathrm{C}-\mathrm{NMR}\left(\mathrm{CDCl}_{3}\right): \delta 171.96,171.90$, 156.64, 155.82, 154.44, 153.53, 152.67, 142.16, 142.65, 140.66, 140.52, 137.24, 137.15, 136.42, 136.28, 135.92, $135.28,134.91,131.59,131.55,130.25,130.18,129.82,129.50,129.45,129.23,128.87,127.40,125.56,120.82$, $120.68,115.64,114.94,114.62,113.91,113.40,112.66,105.56,105.47,105.49,65.83,66.46,55.60,55.41$, 53.01, 47.46, 38.71, 38.63, 28.63, 28.55, 13.20, 13.17. IR: $v_{\max }(\mathrm{KBr}) \mathrm{cm}^{-1}: 3250.6,2930.1,1735.4,1605.6$, 1605.1, 1244.1, 1037.1, 835.6. HRMS (EI): Found 708.2937 [M + Na] ${ }^{+}, \mathrm{C}_{43} \mathrm{H}_{43} \mathrm{NO}_{7} \mathrm{Na}$ requires 708.2937.

(E/Z)-3-(3,4-Dimethoxyphenyl)-N-(2-(4-((Z)-1-(4-hydroxyphenyl)-2-phenylbut-1-en-1-yl)phenoxy)ethyl)-Nmethyl-2-(3,4,5-trimethoxyphenyl)acrylamide (3g). Following the general method above, the acrylic acid $1 \mathrm{~g}$ (1.2 eq., $184 \mathrm{mg}, 0.492 \mathrm{mmol})$ ), EDC (1.4 eq., $110 \mathrm{mg}, 0.572 \mathrm{mmol}$ ), and HOBt (1.4 eq., $77.6 \mathrm{mg}$, $0.572 \mathrm{mmol}$ ) was reacted with endoxifen derivative $2 \mathrm{a}(1 \mathrm{eq} ., 200 \mathrm{mg}, 0.41 \mathrm{mmol})$. Purification by flash chromatography over silica gel (DCM:EtOAc, gradient 20:1 to 10:1) afforded a white solid, (300 mg, 87\%). HRMS: Found $866.4046\left[\mathrm{M}+\mathrm{Na}^{+}, \mathrm{C}_{51} \mathrm{H}_{61} \mathrm{NO}_{8} \mathrm{NaSi}\right.$ requires 866.4046. The silyl ether $(176 \mathrm{mg}$, $0.21 \mathrm{mmol}$ ) was dissolved in THF ( $3 \mathrm{~mL}$ ) and stirred under nitrogen. A solution of TBAF (1 M in THF, 1 eq., $0.21 \mathrm{~mL}, 0.21 \mathrm{mmol}$ ) was added to the mixture and allowed to stir for $1 \mathrm{~h}$. The mixture was evaporated to dryness under reduced pressure. The material was purified via flash chromatography over silica gel (DCM:EtOAc, gradient 6:1 to 3:1) to afford the product as a white solid. (139 $\mathrm{mg}, 91 \%)$, m.p. 63-66 ${ }^{\circ} \mathrm{C} .{ }^{1} \mathrm{H}-\mathrm{NMR}\left(\mathrm{CDCl}_{3}\right) \delta 6.99-7.19(\mathrm{~m}, 13 \mathrm{H}, \mathrm{Ar}-\mathrm{H}, \mathrm{C}=\mathrm{CH}), 6.29-6.87(\mathrm{~m}, 25 \mathrm{H}, \mathrm{Ar}-\mathrm{H}), 5.89$ (br. s., $1 \mathrm{H}, \mathrm{OH}), 4.02-4.26\left(\mathrm{~m}, 4 \mathrm{H}, \mathrm{CH}_{2}\right), 3.51-3.87\left(\mathrm{~m}, 34 \mathrm{H}, \mathrm{OCH}_{3}, \mathrm{CH}_{2}\right), 2.98-3.24\left(\mathrm{~m}, 6 \mathrm{H}, \mathrm{NCH}_{3}\right)$, 2.38-2.51 (m, 4H, $\left.\mathrm{CH}_{2}\right), 0.85-0.95\left(\mathrm{~m}, 6 \mathrm{H}, \mathrm{CH}_{3}\right) .{ }^{13} \mathrm{C}-\mathrm{NMR}\left(\mathrm{CDCl}_{3}\right) \delta 171.6(\mathrm{C}=\mathrm{O}), 161.0,154.9,154.0$, 152.7, 152.6, 142.6, 141.0, 137.9, 137.7, 136.7, 135.7, 132.0, 130.6, 130.4, 129.7, 129.6, 127.8, 127.8, 125.9, 115.0, 114.3, 113.9, 113.2, 106.8, 106.7, 100.5, $60.8\left(\mathrm{CH}_{2}\right), 60.4\left(\mathrm{OCH}_{3}\right), 55.8\left(\mathrm{OCH}_{3}\right), 55.4\left(\mathrm{OCH}_{3}\right), 38.9$ $\left(\mathrm{NCH}_{3}\right), 25.6\left(\mathrm{CH}_{2}\right), 13.6\left(\mathrm{CH}_{3}\right), 13.6\left(\mathrm{CH}_{3}\right)$. IR: $v_{\max }(\mathrm{KBr}) \mathrm{cm}^{-1}: 3242.0,2934.9,2837.9,2837.6,1736.1$, 1600.2, 1505.9, 1421.4, 1239.7, 1155.4, 833.2 HRMS (EI): Found 752.3210 [M + Na] ${ }^{+}, \mathrm{C}_{45} \mathrm{H}_{47} \mathrm{NO}_{8} \mathrm{Na}$ requires 752.3199 . 
(E/Z)-N-(2-(4-((Z)-1-(4-Hydroxyphenyl)-2-phenylbut-1-en-1-yl)phenoxy)ethyl)-N-methyl-3-(2,3,4-trimethoxyphenyl)-2-(3,4,5-trimethoxyphenyl)acrylamide (3h). Following the general method above, the acrylic acid analogue $\mathbf{1 h}$ was reacted with endoxifen derivative $\mathbf{2} \mathbf{a}$. The final product was purified by flash chromatography over silica gel (DCM:EtOAc, gradient 6:1 to 3:1) to afford the product as a brown resin (26\%). ${ }^{1} \mathrm{H}-\mathrm{NMR}\left(\mathrm{CDCl}_{3}\right): \delta 7.16-6.43(\mathrm{~m}, 36 \mathrm{H}, \mathrm{Ar}-\mathrm{H}, \mathrm{C}=\mathrm{CH}), 4.12-3.55\left(\mathrm{~m}, 40 \mathrm{H}, \mathrm{OCH}, \mathrm{N}^{-\mathrm{CH}} \mathrm{CH}_{2}\right.$ $\left.\mathrm{O}-\mathrm{CH}_{2}\right), 3.12-3.10\left(\mathrm{~m}, 6 \mathrm{H}, \mathrm{NCH}_{3}\right), 2.50-2.47\left(\mathrm{~m}, 4 \mathrm{H}, \mathrm{CH}_{2}\right), 0.94-0.91\left(\mathrm{t}, 6 \mathrm{H}, \mathrm{J}=7.5 \mathrm{~Hz} \mathrm{CH}_{3}\right)^{13} \mathrm{C}-\mathrm{NMR}$ $\left(\mathrm{CDCl}_{3}\right): \delta 170.7(\mathrm{C}=\mathrm{O}), 155.0\left(\mathrm{C}_{\mathrm{q}}\right), 154.2\left(\mathrm{C}_{\mathrm{q}}\right), 153.4\left(\mathrm{C}_{\mathrm{q}}\right), 152.7\left(\mathrm{C}_{\mathrm{q}}\right), 152.7\left(\mathrm{C}_{\mathrm{q}}\right), 142.6\left(\mathrm{C}_{\mathrm{q}}\right), 142.5\left(\mathrm{C}_{\mathrm{q}}\right)$, $141.0\left(\mathrm{C}_{\mathrm{q}}\right), 137.8\left(\mathrm{C}_{\mathrm{q}}\right), 137.8\left(\mathrm{C}_{\mathrm{q}}\right), 137.6\left(\mathrm{C}_{\mathrm{q}}\right), 136.6\left(\mathrm{C}_{\mathrm{q}}\right), 135.6\left(\mathrm{C}_{\mathrm{q}}\right), 135.2\left(\mathrm{C}_{\mathrm{q}}\right), 132.0(\operatorname{ArC}), 131.9(\operatorname{ArC})$, 130.6 (ArC), 130.6 (ArC), 130.5 (ArC), 129.6 (ArC), 129.6 (ArC), 127.8 (ArC), $125.9(\operatorname{ArC}), 115.0(\mathrm{ArC})$, 114.3 (ArC), 113.9 (ArC), 113.1 (ArC), 106.7 (ArC), 106.6 (ArC), 106.1 (ArC), $106.1(\mathrm{ArC}), 60.9\left(\mathrm{CH}_{2}\right)$, $60.82\left(\mathrm{OCH}_{3}\right), 60.81\left(\mathrm{OCH}_{3}\right), 60.4\left(\mathrm{OCH}_{3}\right), 56.1\left(\mathrm{OCH}_{3}\right), 55.8\left(\mathrm{OCH}_{3}\right)$, 53.4, 47.7, $39.0\left(\mathrm{NCH}_{3}\right) 29.1$ $\left(\mathrm{CH}_{2}\right), 29.0\left(\mathrm{CH}_{2}\right), 13.6\left(\mathrm{CH}_{3}\right), 13.56\left(\mathrm{CH}_{3}\right) . \mathrm{IR}: v_{\max }(\mathrm{KBr}) \mathrm{cm}^{-1}$ : 3167.5, 2935.3, 1737.4, 1581.6, 1505.6, 1233.1, 1125.0, 1003.7, 834.9. HRMS (EI): Found 782.3310 [M+ Na] ${ }^{+}, \mathrm{C}_{46} \mathrm{H}_{49} \mathrm{NO}_{9} \mathrm{Na}$ requires 782.3305.

(E/Z)-2-(3-Hydroxy-4-methoxyphenyl)-N-(2-(4-((Z)-1-(4-hydroxyphenyl)-2-phenylbut-1-en-1-yl)phenoxy)ethyl)-N-methyl-3-(3,4,5-trimethoxyphenyl)acrylamide (3i). Following the general method above, the acrylic acid $1 \mathbf{i}(1.2$ eq., $177 \mathrm{mg}, 0.492 \mathrm{mmol})$ ), EDC (1.4 eq., $110 \mathrm{mg}, 0.572 \mathrm{mmol})$ and HOBt (1.4 eq., $77.6 \mathrm{mg}, 0.572 \mathrm{mmol}$ ) was reacted with endoxifen derivative 2a (1 eq., $200 \mathrm{mg}, 0.41 \mathrm{mmol}$ ). Purification by flash chromatography over silica gel (DCM:EtOAc, gradient 20:1 to 10:1) afforded the product as a white solid. (289 mg, 85\%), HRMS: Found $852.3920[\mathrm{M}+\mathrm{Na}]^{+}, \mathrm{C}_{50} \mathrm{H}_{59} \mathrm{NO}_{8} \mathrm{NaSi}$ requires 852.3908 . The silyl ether $(137 \mathrm{mg}, 0.16 \mathrm{mmol})$ was dissolved in THF $(3 \mathrm{~mL})$ and stirred under nitrogen. A solution of TBAF ( $1 \mathrm{M}$ in THF, 1 eq., $0.16 \mathrm{~mL}, 0.16 \mathrm{mmol}$ ) was added to the mixture and allowed to stir for $1 \mathrm{~h}$. The mixture was evaporated to dryness under reduced pressure. The material was purified by flash chromatography over silica gel (DCM:EtOAc, gradient 6:1 to 3:1) to afford the product as a white solid. (103 mg, 90\%), m.p: 81-83 ${ }^{\circ} \mathrm{C}$. (DCM:EtOAc). ${ }^{1} \mathrm{H}-\mathrm{NMR}\left(\mathrm{CDCl}_{3}\right) \delta 6.99-7.19$ $(\mathrm{m}, 15 \mathrm{H}, \mathrm{Ar}-\mathrm{H}, \mathrm{C}=\mathrm{CH}), 5.85-6.88(\mathrm{~m}, 23 \mathrm{H}, \mathrm{Ar}-\mathrm{H}), 4.05-4.29\left(\mathrm{~m}, 4 \mathrm{H}, \mathrm{CH}_{2}\right), 3.49-3.89\left(\mathrm{~m}, 28 \mathrm{H}, \mathrm{OCH}_{3}\right.$, $\left.\mathrm{CH}_{2}\right), 2.91-3.25\left(\mathrm{~m}, 6 \mathrm{H}, \mathrm{NCH}_{3}\right), 2.39-2.50\left(\mathrm{~m}, 4 \mathrm{H}, \mathrm{CH}_{2}\right), 0.85-0.94\left(\mathrm{~m}, 6 \mathrm{H}, \mathrm{CH}_{3}\right) .{ }^{13} \mathrm{C}-\mathrm{NMR}\left(\mathrm{CDCl}_{3}\right) \delta$ 171.2 (C=O), 168.7, 154.9, 154.0, 153.4, 151.7, 151.7, 135.7, 133.3, 132.0, 131.9, 130.7, 130.6, 129.6, 129.6, $128.3,127.9,127.8,125.9,115.0,114.3,113.9,113.1,106.1,106.0,60.8\left(\mathrm{OCH}_{3}\right), 60.4\left(\mathrm{CH}_{2}\right), 56.3\left(\mathrm{OCH}_{3}\right)$, $56.2\left(\mathrm{OCH}_{3}\right), 56.1\left(\mathrm{OCH}_{3}\right), 55.9\left(\mathrm{OCH}_{3}\right), 29.04\left(\mathrm{CH}_{2}\right), 28.97\left(\mathrm{CH}_{2}\right), 13.6\left(\mathrm{CH}_{3}\right), 13.57\left(\mathrm{CH}_{3}\right) . \mathrm{IR:} v_{\max }$ $(\mathrm{KBr}) \mathrm{cm}^{-1}:$ 3428.1, 2935.6, 2346.1, 1766.2, 1596.7, 1508.0, 1239.8, 1127.5, 835.0. HRMS (EI): Found $716.3226[\mathrm{M}+\mathrm{H}]^{+}, \mathrm{C}_{44} \mathrm{H}_{46} \mathrm{NO}_{8}$ requires 716.3223 .

(E/Z)-3-(4-Hydroxy-3,5-dimethoxyphenyl)-N-(2-(4-((Z)-1-(4-hydroxyphenyl)-2-phenylbut-1-en-1-yl)-phenoxy) ethyl)-N-methyl-2-(3,4,5-trimethoxyphenyl)acrylamide (3j). Following the general method above, the acrylic acid 1j (1.2 eq., $194 \mathrm{mg}, 0.492 \mathrm{mmol})$, EDC (1.4 eq., $110 \mathrm{mg}, 0.572 \mathrm{mmol}$ ) and HOBt (1.4 eq., $77.6 \mathrm{mg}, 0.572 \mathrm{mmol}$ ) was reacted with endoxifen derivative $2 \mathrm{a}$ (1 eq., $200 \mathrm{mg}, 0.41 \mathrm{mmol}$ ). Purification by flash chromatography over silica gel (DCM:EtOAc, gradient 20:1 to 10:1) afforded the product as a white solid. (315 mg, 76\%), HRMS: Found 882.4022 [M $+\mathrm{Na}]^{+}, \mathrm{C}_{51} \mathrm{H}_{61} \mathrm{NO}_{9} \mathrm{NaSi}$ requires 882.4013. The silyl ether (158 mg, $0.18 \mathrm{mmol})$ was dissolved in THF ( $3 \mathrm{~mL})$ and stirred under nitrogen environment. A solution of TBAF ( $1 \mathrm{M}$ in THF, 1 eq., $0.18 \mathrm{~mL}, 0.18 \mathrm{mmol}$ ) was added to the mixture and allowed to stir for $1 \mathrm{~h}$. The solvent was evaporated under reduced pressure and the residue was purified by flash chromatography over silica gel (DCM:EtOAc, gradient 6:1 to 3:1) to afford the product as a white solid (128 mg, 94\%), m.p: 76-79 ${ }^{\circ} \mathrm{C} .{ }^{1} \mathrm{H}-\mathrm{NMR}\left(\mathrm{CDCl}_{3}\right) \delta 6.97-7.19(\mathrm{~m}, 14 \mathrm{H}, \mathrm{Ar}-\mathrm{H}$, $\mathrm{C}=\mathrm{CH}), 6.30-6.89(\mathrm{~m}, 24 \mathrm{H}, \mathrm{Ar}-\mathrm{H}), 4.02-4.27\left(\mathrm{~m}, 4 \mathrm{H}, \mathrm{CH}_{2}\right), 3.52-3.95\left(\mathrm{~m}, 34 \mathrm{H}, \mathrm{CH}_{2}, \mathrm{OCH}_{3}\right), 2.98-3.29$ $\left(\mathrm{m}, 6 \mathrm{H}, \mathrm{NCH}_{3}\right), 2.37-2.53\left(\mathrm{~m}, 4 \mathrm{H}, \mathrm{CH}_{2}\right), 0.83-0.96\left(\mathrm{~m}, 6 \mathrm{H}, \mathrm{CH}_{3}\right) .{ }^{13} \mathrm{C}-\mathrm{NMR}\left(\mathrm{CDCl}_{3}\right) \delta 171.3(\mathrm{C}=\mathrm{O})$, 155.0, 154.1, 153.4, 152.7, 152.7, 142.6, 142.5, 141.0, 137.8, 137.8, 137.6, 136.6, 135.6, 135.2, 132.0, 131.9, $130.6,130.6,130.5,129.6,129.6,127.8,125.9,115.0,114.3,113.9,113.1,106.7,106.6,106.1,106.1,60.9$ $\left(\mathrm{CH}_{2}\right), 60.82\left(\mathrm{OCH}_{3}\right), 60.81\left(\mathrm{OCH}_{3}\right), 60.4\left(\mathrm{OCH}_{3}\right), 56.1\left(\mathrm{OCH}_{3}\right), 55.8\left(\mathrm{OCH}_{3}\right), 53.4,47.7,39.0\left(\mathrm{NCH}_{3}\right)$ $29.1\left(\mathrm{CH}_{2}\right), 29.0\left(\mathrm{CH}_{2}\right), 13.6\left(\mathrm{CH}_{3}\right), 13.56\left(\mathrm{CH}_{3}\right)$. IR: $v_{\max }(\mathrm{KBr}) \mathrm{cm}^{-1}:$ 3167.5, 2935.3, 1737.4, 1581.6, 
1505.6, 1233.1, 1125.0, 1003.7 834.9. HRMS (EI): Found $768.3133[\mathrm{M}+\mathrm{Na}]^{+}, \mathrm{C}_{45} \mathrm{H}_{47} \mathrm{NO}_{9} \mathrm{Na}$ requires 768.3149.

(E/Z)-N-(2-(4-((E)-1-(4-Hydroxyphenyl)-2-phenylbut-1-en-1-yl)phenoxy)ethyl)-N-methyl-3-(5-methylthiophen-2-yl)-2-(3,4,5-trimethoxyphenyl)acrylamide (31). Following the general method above, the acrylic acid $1 p$ (1.2 eq., $165 \mathrm{mg}, 0.492 \mathrm{mmol}$ ), EDC (1.4 eq., $110 \mathrm{mg}, 0.572 \mathrm{mmol}$ ) and HOBt (1.4 eq., $77.6 \mathrm{mg}$, $0.572 \mathrm{mmol}$ ) was reacted with endoxifen derivative $2 \mathrm{a}(1 \mathrm{eq} ., 200 \mathrm{mg}, 0.41 \mathrm{mmol})$. The product was purified by flash chromatography over silica gel (DCM:EtOAc, gradient 20:1 to 10:1) to afford a white solid (184 mg, 56\%). HRMS: Found $826.3604[\mathrm{M}+\mathrm{Na}]^{+}, \mathrm{C}_{48} \mathrm{H}_{57} \mathrm{NO}_{6} \mathrm{NaSiS}$ requires 826.3574. The silyl ether $(101 \mathrm{mg}, 0.126 \mathrm{mmol})$ was dissolved in (THF) $3 \mathrm{~mL}$ and stirred under nitrogen environment. A solution of TBAF ( $1 \mathrm{M}$ in THF, 1 eq., $0.126 \mathrm{~mL}, 0.126 \mathrm{mmol}$ ) was added to the mixture and allowed to stir for $1 \mathrm{~h}$. The mixture was evaporated to dryness under reduced pressure. The material was purified via flash chromatography over silica gel (DCM:EtOAc, gradient 6:1 to 3:1) to afford the product as a white solid. $(70 \mathrm{mg}, 81 \%), \mathrm{m} . \mathrm{p}: 83-84{ }^{\circ} \mathrm{C} .{ }^{1} \mathrm{H}-\mathrm{NMR}\left(\mathrm{CDCl}_{3}\right): \delta 5.82-7.24(\mathrm{~m}, 34 \mathrm{H}, \mathrm{Ar}-\mathrm{H}$, $\mathrm{C}=\mathrm{CH}), 3.99-4.33\left(\mathrm{~m}, 4 \mathrm{H}, \mathrm{CH}_{2}\right), 3.72-3.96\left(\mathrm{~m}, 22 \mathrm{H}, \mathrm{CH}_{2}, \mathrm{OCH}_{3}\right), 2.97-3.37\left(\mathrm{~m}, 6 \mathrm{H}, \mathrm{NCH}_{3}\right), 2.43-2.56$ $\left(\mathrm{m}, 4 \mathrm{H}, \mathrm{CH}_{2}\right), 2.37\left(\mathrm{~d}, \mathrm{~J}=3.26 \mathrm{~Hz}, 6 \mathrm{H}, \mathrm{CH}_{3}\right), 0.94\left(\mathrm{~s}, 6 \mathrm{H}, \mathrm{CH}_{3}\right) .{ }^{13} \mathrm{C}-\mathrm{NMR}\left(\mathrm{CDCl}_{3}\right): \delta 171.3(\mathrm{C}=\mathrm{O})$, 157.1, 156.3, 154.9, 154.0, 153.6, 153.6, 142.8, 142.7, 142.6, 142.5, 141.1, 141.0, 138.3, 138.2, 137.7, 136.9, 136.0, 135.8, 135.4, 132.3, 132.3, 132.0, 131.4, 131.4, 130.7, 129.7, 127.9, 125.9, 125.7, 125.6, 124.7, 124.7, $115.1,114.4,113.9,113.2,106.4,106.3,61.0\left(\mathrm{OCH}_{3}\right), 60.5\left(\mathrm{CH}_{2}\right), 56.3\left(\mathrm{OCH}_{3}\right), 56.2\left(\mathrm{OCH}_{3}\right), 38.7\left(\mathrm{NCH}_{3}\right)$ $\left(\mathrm{CH}_{2}\right), 29.1\left(\mathrm{CH}_{2}\right), 29.0\left(\mathrm{CH}_{2}\right), 15.5\left(\mathrm{CH}_{3}\right), 13.7\left(\mathrm{CH}_{3}\right), 13.6\left(\mathrm{CH}_{3}\right)$. IR: $v_{\max }(\mathrm{KBr}) \mathrm{cm}^{-1}: 3255.2,2961.7$, 2932.4, 1735.6, 1605.5, 1580.2, 1505.9, 1238.4, 1120.2, 834.0. HRMS (EI): Found 712.2720 [M + Na] ${ }^{+}$, $\mathrm{C}_{42} \mathrm{H}_{43} \mathrm{NNaO}_{6} \mathrm{~S}$ requires 712.2709.

(E/Z)-3-(Furan-3-yl)-N-(2-(4-((E)-1-(4-hydroxyphenyl)-2-phenylbut-1-en-1-yl)phenoxy)ethyl)-N-methyl-2(3,4,5-trimethoxyphenyl)acrylamide (3m). Following the general method above, the acrylic acid $\mathbf{1 q}$ (1.2 eq., $149 \mathrm{mg}, 0.492 \mathrm{mmol}$ ), EDC (1.4 eq., $110 \mathrm{mg}, 0.572 \mathrm{mmol}$ ) and HOBt (1.4 eq., $77.6 \mathrm{mg}, 0.572$ $\mathrm{mmol}$ ) was reacted with endoxifen derivative $2 \mathrm{a}$ (1 eq., $200 \mathrm{mg}, 0.41 \mathrm{mmol})$. Purification by flash chromatography over silica gel (DCM:EtOAc, gradient 20:1 to 10:1) afforded the product as a white solid. (89 mg, 32\%), HRMS: Found $796.3656[\mathrm{M}+\mathrm{Na}]^{+}, \mathrm{C}_{47} \mathrm{H}_{55} \mathrm{NO}_{7} \mathrm{NaSi}$ requires 796.3646. The silyl ether $(70 \mathrm{mg}, 0.09 \mathrm{mmol})$ was dissolved in THF $(3 \mathrm{~mL})$ and stirred under nitrogen. A solution of TBAF (1M in THF, 1 eq., $0.09 \mathrm{~mL}, 0.09 \mathrm{mmol}$ ) was added to the mixture and allowed to stir for $1 \mathrm{~h}$. The solvent was evaporated under reduced pressure. Purification by flash chromatography over silica gel afforded the product as a white solid. (29 mg, 50\%), m.p: 81-84 ${ }^{\circ} \mathrm{C} .{ }^{1} \mathrm{H}-\mathrm{NMR}\left(\mathrm{CDCl}_{3}\right) \delta 7.55-7.66$ $\left(\mathrm{m}, 2 \mathrm{H}, \mathrm{Ar}-\mathrm{H}, \mathrm{CCH}_{2}\right), 5.90-7.47\left(\mathrm{~m}, 40 \mathrm{H}, \mathrm{Ar}-\mathrm{H}, \mathrm{C}=\mathrm{CH}, \mathrm{C}=\mathrm{C}_{2}\right), 4.00-4.32\left(\mathrm{~m}, 4 \mathrm{H}, \mathrm{CH}_{2}\right), 3.66-3.99$ $\left(\mathrm{m}, 22 \mathrm{H}, \mathrm{OCH}_{3}, \mathrm{CH}_{2}\right), 3.02-3.30\left(\mathrm{~m}, 6 \mathrm{H}, \mathrm{NCH}_{3}\right), 2.43-2.56\left(\mathrm{~m}, 4 \mathrm{H}, \mathrm{CH}_{2}\right), 0.90-1.00\left(\mathrm{~m}, 6 \mathrm{H}, \mathrm{CH}_{3}\right)$. ${ }^{13} \mathrm{C}-\mathrm{NMR}\left(\mathrm{CDCl}_{3}\right): \delta 171.7(\mathrm{C}=\mathrm{O}), 154.8,153.9,153.4,153.3,143.6,142.9,142.9,142.6,142.5,141.1,137.9$, 137.7, 135.8, 135.6, 135.5, 135.5, 132.0, 130.7, 130.7, 129.7, 127.9, 126.0, 121.3, 121.3, 115.1, 114.4, 113.9, 113.1, 110.0, 106.0, 105.9, $66.2\left(\mathrm{OCH}_{3}\right), 61.0\left(\mathrm{OCH}_{3}\right), 60.5\left(\mathrm{CH}_{2}\right), 56.1\left(\mathrm{OCH}_{3}\right), 39.1\left(\mathrm{NCH}_{3}\right), 29.1\left(\mathrm{CH}_{2}\right)$, $29.0\left(\mathrm{CH}_{2}\right), 13.7\left(\mathrm{CH}_{3}\right), 13.6\left(\mathrm{CH}_{3}\right)$. HRMS (EI): Found $682.2791[\mathrm{M}+\mathrm{Na}]^{+}, \mathrm{C}_{41} \mathrm{H}_{41} \mathrm{NNaO}_{7}$ requires 682.2781 .

(E)-N,N-Diethyl-3-(4-methoxyphenyl)-2-(3,4,5-trimethoxyphenyl)acrylamide (3q). The acrylic acid 1 n (1 eq., $0.87 \mathrm{mmol}, 0.3 \mathrm{~g}$ ) was reacted with Mukaiyama's reagent (3 eq., $2.61 \mathrm{mmol}, 0.67 \mathrm{~g})$ in dry DCM $(20 \mathrm{~mL})$. After stirring for $5 \mathrm{~min}$, diethylamine (1 eq., $0.87 \mathrm{mmol}, 0.06 \mathrm{~g}$ ) and trimethylamine ( 5 eq., $4.35 \mathrm{mmol}$, $0.44 \mathrm{~g}, 0.60 \mathrm{~mL}$ ) were added. The reaction was stirred at room temperature for $3 \mathrm{~h}$. After completion the mixture was diluted with $\mathrm{DCM}$ and washed with $\mathrm{HCl} 10 \%(10 \mathrm{~mL}), \mathrm{NaHCO}_{3}$ sat $(10 \mathrm{~mL})$, water $(10 \mathrm{~mL})$, brine $(10 \mathrm{~mL})$ and dried over sodium sulphate. The crude material was then purified via flash column chromatography (eluent, DCM: ethylacetate 1:1) to afford the product as a pale yellow oil, $(63 \%, 0.215 \mathrm{~g}) .{ }^{1} \mathrm{H}-\mathrm{NMR}\left(\mathrm{CDCl}_{3}\right) \delta 7.08(\mathrm{~d}, J=8.8 \mathrm{~Hz}, 2 \mathrm{H}, \mathrm{Ar}-\mathrm{H}), 6.70(\mathrm{~d}, J=8.7 \mathrm{~Hz}, 2 \mathrm{H}, \mathrm{Ar}-\mathrm{H})$, $6.55(\mathrm{~s}, 1 \mathrm{H}, \mathrm{CH}), 6.54(\mathrm{~s}, 2 \mathrm{H}, \mathrm{Ar}-\mathrm{H}), 3.82\left(\mathrm{~s}, 3 \mathrm{H}, \mathrm{OCH}_{3}\right), 3.73\left(\mathrm{~s}, 3 \mathrm{H}, \mathrm{OCH}_{3}\right), 3.66\left(\mathrm{~s}, 6 \mathrm{H}, \mathrm{OCH}_{3}\right), 3.39(\mathrm{~s}$, $\left.4 \mathrm{H}, \mathrm{CH}_{2}\right), 1.06\left(\mathrm{~d}, J=62.4 \mathrm{~Hz}, 6 \mathrm{H}, \mathrm{CH}_{3}\right) .{ }^{13} \mathrm{C}-\mathrm{NMR}\left(\mathrm{CDCl}_{3}\right) \delta 171.10(\mathrm{C}=\mathrm{O}), 159.08(\mathrm{C}), 153.22(2 \times \mathrm{C})$, $137.70(\mathrm{CH}), 136.21(\mathrm{C}), 130.96(\mathrm{C}), 130.73(2 \times \mathrm{CH}), 128.46(\mathrm{C}), 127.90(\mathrm{C}), 113.48(2 \times \mathrm{CH}), 105.94$ 
$(2 \times \mathrm{CH}), 60.90\left(\mathrm{OCH}_{3}\right), 56.03\left(2 \times \mathrm{OCH}_{3}\right), 55.17\left(\mathrm{OCH}_{3}\right), 43.02\left(2 \times \mathrm{CH}_{2}\right), 14.15\left(2 \times \mathrm{CH}_{3}\right) . \mathrm{IR}: v_{\max }$ $(\mathrm{KBr}) \mathrm{cm}^{-1}$ : 3368, 2935, 2836, 1668, 1603, 1578, 1507, 1454, 1379, 1275, 1237, 1122, 1028, 1002, 908, 811, $729,637,569$. HRMS (APCI): Found $400.2113(\mathrm{M}+\mathrm{H}) \mathrm{C}_{23} \mathrm{H}_{30} \mathrm{NO}_{5}$ requires 400.2118.

(E)-2-(4-Methoxyphenyl)-3-(3,4,5-trimethoxyphenyl)acrylamide (3n). The acrylic acid $1 \mathbf{p}$ (1 eq., $0.87 \mathrm{mmol}$, $0.3 \mathrm{~g}$ ) was reacted with oxalyl chloride (4 eq., $3.48 \mathrm{mmol}, 0.44 \mathrm{~g}, 0.3 \mathrm{~mL}$ ) and DMF in catalytic amount and stirred in dry DCM at room temperature overnight. The product was concentrated and used for the following step without purification. The residue of the chlorination was redissolved in DCM and reacted with $4 \mathrm{~mL}$ of $28 \%$ aqueous ammonium hydroxide to afford the product as a yellow oil (50\%). ${ }^{1} \mathrm{H}-\mathrm{NMR}\left(\mathrm{DMSO}-d_{6}\right), \delta 7.37$ (s, 1H, CH), $7.20(\mathrm{~s}, 1 \mathrm{H}, \mathrm{H}), 7.09$ (d, J = 8.7 Hz, 2H, Ar-H), 6.99 (d, $J=8.8 \mathrm{~Hz}, 2 \mathrm{H}, \mathrm{Ar}-\mathrm{H}), 6.62(\mathrm{~s}, 1 \mathrm{H}, \mathrm{H}), 6.30(\mathrm{~s}, 2 \mathrm{H}, \mathrm{Ar}-\mathrm{H}), 3.74\left(\mathrm{~s}, 3 \mathrm{H}, \mathrm{OCH}_{3}\right), 3.57\left(\mathrm{~s}, 3 \mathrm{H}, \mathrm{OCH}_{3}\right), 3.45(\mathrm{~s}$, $\left.6 \mathrm{H}, \mathrm{OCH}_{3}\right) .{ }^{13} \mathrm{C}-\mathrm{NMR}\left(\mathrm{DMSO}-d_{6}\right) \delta 169.25,159.38(\mathrm{C}), 152.65,137.96,135.68,134.79,131.20,130.83$, 129.11, 115.00, 107.90, $60.41\left(\mathrm{OCH}_{3}\right), 55.73\left(2 \times \mathrm{OCH}_{3}\right), 55.65\left(\mathrm{OCH}_{3}\right) . \mathrm{IR}: v_{\max }(\mathrm{KBr}) \mathrm{cm}^{-1}: 3375,2935$, 2839, 1672 1593, 1579, 1451, 1424, 1301, 1210, 1234, 1121, 904, 833, 807, 775, 730, 688, 610, 565. HRMS (APCI): Found $344.1485(\mathrm{M}+\mathrm{H}) \mathrm{C}_{19} \mathrm{H}_{22} \mathrm{NO}_{5}$ requires 344.1492 .

(E)-N,N-diethyl-3-(3-hydroxy-4-methoxyphenyl)-2-(3,4,5-trimethoxyphenyl) acrylamide (3o). Following the general method given above for compound 3q, the acrylic acid 11 (1 eq., 1.38 mmol, $0.5 \mathrm{~g}$ ) was reacted with Mukaiyama's reagent (3 eq., $4.16 \mathrm{mmol}, 1.06 \mathrm{~g}$ ) in dry DCM (20 mL). After stirring for $5 \mathrm{~min}$, diethylamine (1 eq., $1.38 \mathrm{mmol}, 0.1 \mathrm{~g}$ ) and trimethylamine ( 5 eq., $6.9 \mathrm{mmol}, 0.69 \mathrm{~g}, 0.96 \mathrm{~mL}$ ) were added. The reaction was stirred at room temperature for $3 \mathrm{~h}$. After completion, the mixture was diluted with DCM and washed with $\mathrm{HCl} 10 \%(10 \mathrm{~mL}), \mathrm{NaHCO}_{3}$ sat $(10 \mathrm{~mL})$, water $(10 \mathrm{~mL})$, brine $(10 \mathrm{~mL})$ and dried over sodium sulphate., to afford the product as an oil ${ }^{1} \mathrm{H}-\mathrm{NMR}\left(\mathrm{CDCl}_{3}\right) \delta 7.26(\mathrm{~s}, 1 \mathrm{H}, \mathrm{Ar}-\mathrm{H}), 7.21$ $(\mathrm{d}, J=8.7 \mathrm{~Hz}, 1 \mathrm{H}, \mathrm{Ar}-\mathrm{H}), 6.93(\mathrm{~d}, J=8.7 \mathrm{~Hz}, 1 \mathrm{H}, \mathrm{Ar}-\mathrm{H}), 6.68$ (s, 1H, Ar-H), 6.52 (s, 2H, Ar-H), 3.80 (s, $\left.3 \mathrm{H}, \mathrm{OCH}_{3}\right), 3.76\left(\mathrm{~s}, 3 \mathrm{H}, \mathrm{OCH}_{3}\right), 3.71\left(\mathrm{~s}, 6 \mathrm{H}, \mathrm{OCH}_{3}\right), 3.59\left(\mathrm{~s}, 4 \mathrm{H}, \mathrm{CH}_{2}\right), 1.16\left(\mathrm{~s}, 3 \mathrm{H}, \mathrm{CH}_{3}\right), 0.97(\mathrm{~s}, 3 \mathrm{H}$, $\left.\mathrm{CH}_{3}\right) .{ }^{13} \mathrm{C}-\mathrm{NMR}\left(\mathrm{CDCl}_{3}\right), \delta 159.20,153.43,149.35,148.41,138.93,138.79,130.11,129.46,126.99,123.63$, $120.79,113.07,106.02,60.97\left(\mathrm{OCH}_{3}\right), 56.48\left(2 \times \mathrm{OCH}_{3}\right), 56.41\left(\mathrm{OCH}_{3}\right), 46.58\left(2 \times \mathrm{CH}_{2}\right), 13.89\left(\mathrm{CH}_{3}\right)$, $12.68\left(\mathrm{CH}_{3}\right)$. IR: $v_{\max }(\mathrm{KBr}) \mathrm{cm}^{-1}: 3399,2935,1651,1637,1578,1506,1448,1413,1381,1288,1238,1157$, $1119,1017,971,808,773,569$. HRMS (APCI): Found 416.2049 (M+ H) $\mathrm{C}_{23} \mathrm{H}_{30} \mathrm{NO}_{6}$ requires 416.2067.

(E)-3-(4-Methoxyphenyl)-2-(3,4,5-trimethoxyphenyl)acrylamide (3p). To a solution of acrylic acid $\mathbf{1 1}$ (2 mmol, $0.68 \mathrm{~g})$ in dichloromethane $(7 \mathrm{~mL})$, triethylamine $(1.2 \mathrm{~mL}, 8.6 \mathrm{mmol})$ and thionyl chloride $(0.27 \mathrm{~mL}$, $3.72 \mathrm{mmol}$ ) were added dropwise. The reaction mixture was stirred at room temperature for $2 \mathrm{~h}$ whereupon it was concentrated to dryness under reduce pressure. To $30 \mathrm{~mL}$ of a $28 \%$ aqueous $\mathrm{NH}_{4} \mathrm{OH}$ solution a solution of the crude residue in dichloromethane $(30 \mathrm{~mL})$ was added. The reaction mixture was vigorously stirred at room temperature overnight, then diluted with water and extracted with dichloromethane. The combined organic layers were dried over anhydrous sodium sulfate, filtered and evaporated to dryness under reduce pressure. The residue was purified by flash chromatography (eluent, DCM/ethyl acetate, $v / v 1: 1)$ to afford the product as white solid $(15 \%, 0.1 \mathrm{~g})$ [71]. ${ }^{1} \mathrm{H}-\mathrm{NMR}$ $\left.\left(\mathrm{DMSO}_{-}\right)_{6}\right) \delta .43(\mathrm{~s}, 1 \mathrm{H}, \mathrm{Ar}-\mathrm{H}), 7.20(\mathrm{~s}, 1 \mathrm{H}, \mathrm{NH}), 6.99(\mathrm{~d}, J=8.8 \mathrm{~Hz}, 2 \mathrm{H}, \mathrm{Ar}-\mathrm{H}), 6.79(\mathrm{~d}, J=8.9 \mathrm{~Hz}, 2 \mathrm{H}$, $\mathrm{Ar}-\mathrm{H}), 6.59$ (s, 1H, NH), 6.44 (s, 2H, Ar-H), $3.72\left(\mathrm{~s}, 3 \mathrm{H}, \mathrm{OCH}_{3}\right), 3.70\left(\mathrm{~s}, 3 \mathrm{H}, \mathrm{OCH}_{3}\right), 3.69\left(\mathrm{~s}, 6 \mathrm{H}, \mathrm{OCH}_{3}\right)$. ${ }^{13} \mathrm{C}-\mathrm{NMR}\left(\mathrm{CDCl}_{3}\right) \delta 169.02,160.20,154.28,137.69,132.23,130.83,127.67,127.10,113.77,106.28,61.04$ $\left(\mathrm{OCH}_{3}\right), 56.22\left(2 \times \mathrm{OCH}_{3}\right), 55.20\left(\mathrm{OCH}_{3}\right) . \mathrm{IR}: v_{\max }(\mathrm{KBr}) \mathrm{cm}^{-1}: 3421,3298,3145,2941,1673,1589,1503$, $1452,1421,1409,1368,1295,1250,1234,1182,1026,994,822,805,772,725,691,652$. HRMS (EI): Found $344.2194(\mathrm{M}+\mathrm{H}) \mathrm{C}_{19} \mathrm{H}_{21} \mathrm{NO}_{5}$ requires 344.1498.

3.2.3. General Method for the Synthesis of Endoxifen-Cinnamic Acid/3-Phenylpropanoic Acid Conjugates 5a-5d

Step (A): A mixture of the appropriate cinnamic acid/3-phenylpropanoic acid (1 eq., $0.154 \mathrm{mmol}$ ), DCC (1 eq., $0.154 \mathrm{mmol}, 32 \mathrm{mg}$ ), and HOBt (1 eq., $0.154 \mathrm{mmol}, 21 \mathrm{mg}$ ) were suspended in anhydrous dichloromethane $(3 \mathrm{~mL})$ and stirred for $10 \mathrm{~min}$ under a nitrogen. The silyl-protected endoxifen derivative $2 \mathrm{a}$ (75 mg, 1 eq., $0.154 \mathrm{mmol})$ was dissolved in anhydrous DCM (3 mL) and slowly added 
to the mixture via syringe. The reaction was allowed stir for $24-48 \mathrm{~h}$ and monitored via TLC. The reaction mixture was diluted to $15 \mathrm{~mL}$ with anhydrous DCM and filtered to remove DCU. The filtrate was evaporated to dryness under reduced pressure and the residue was dissolved in THF ( $3 \mathrm{~mL})$ and stirred under nitrogen atmosphere. A solution of $0.1 \mathrm{M}$ TBAF (2 eq.) was added to the mixture and allowed to stir for $24 \mathrm{~h}$. The solvent was evaporated to dryness under reduced pressure. The residue was dissolved in DCM and was washed with $10 \% \mathrm{HCl}$ solution. The resulting organic phase was dried over sodium sulphate and evaporated to dryness. The material was purified via flash chromatography on silica gel, (eluent: DCM:EtOAc).

Step (B): A mixture of the appropriate cinnamic acid/3-phenylpropanoic acid (1.2 eq), EDC (1.4 eq.), and HOBt (1.4 eq.) were suspended in anhydrous dichloromethane $(3 \mathrm{~mL})$ and stirred for 10 min under a nitrogen atmosphere. The protected endoxifen (1 eq.) 2a was dissolved in anhydrous dichloromethane $(3 \mathrm{~mL})$ and slowly added to the mixture via syringe and the reaction was stirred for 16 $\mathrm{h}$ and monitored via TLC. The reaction mixture was diluted to $15 \mathrm{~mL}$ with anhydrous dichloromethane. To this mixture, water $(20 \mathrm{~mL})$ was added. The aqueous phase was extracted with DCM $(20 \mathrm{~mL} \times 3)$, brine $(50 \mathrm{~mL})$, dried over $\mathrm{Na}_{2} \mathrm{SO}_{4}$ and evaporated to dryness in vacuo to yield the crude product. The material was purified via flash chromatography on silica gel. (eluent: DCM:EtOAc). The above residue was dissolved in THF ( $3 \mathrm{~mL})$ and stirred under nitrogen atmosphere. A solution of TBAF (1 M in THF, 1 eq.) was added to the mixture and allowed to stir for $1 \mathrm{~h}$. The mixture was evaporated to dryness under reduced pressure. The material was purified via flash chromatography over silica gel (eluent: DCM:EtOAc) to afford the product.

(E/Z)-3-(3-Hydroxy-4-methoxyphenyl)-N-(2-(4-((Z)-1-(4-hydroxyphenyl)-2-phenylbut-1-en-1-yl)phenoxy)ethyl)-N-methylacrylamide (5a). Following the general method above, the cinnamic acid 4 a (1.2 eq., $118 \mathrm{mg}, 0.492 \mathrm{mmol})$, EDC (1.4 eq., $110 \mathrm{mg}, 0.572 \mathrm{mmol})$ and HOBt (1.4 eq., $77.6 \mathrm{mg}, 0.572 \mathrm{mmol})$ was reacted with endoxifen derivative $2 \mathbf{a}$ (1 eq., $200 \mathrm{mg}, 0.41 \mathrm{mmol}$ ). Purification by flash chromatography over silica gel (DCM:EtOAc, gradient 10:1 to 10:1) affordrd the product as a white solid, (236 mg, 87\%). HRMS: Found $686.3317[\mathrm{M}+\mathrm{Na}]^{+}, \mathrm{C}_{46} \mathrm{H}_{49} \mathrm{NO}_{5} \mathrm{NaSi}$ requires 686.3278. The silyl ether $(126 \mathrm{mg}, 0.189$ mmol) was dissolved in THF (3 mL). A solution of TBAF ( $1 \mathrm{M}$ in THF, 1 eq., $0.189 \mathrm{~mL}, 0.189 \mathrm{mmol})$ was added to the mixture and stirred under nitrogen for $1 \mathrm{~h}$. The solvent was evaporated under reduced pressure. Purification by flash chromatography over silica gel (DCM:EtOAc, gradient 6:1 to 3:1) afforded the product as a white solid. (94 mg, 94\%), m.p: 77-78 ${ }^{\circ} \mathrm{C} .{ }^{1} \mathrm{H}-\mathrm{NMR}\left(\mathrm{CDCl}_{3}\right) \delta 7.51-7.65$ $(\mathrm{m}, 2 \mathrm{H}, \mathrm{C}=\mathrm{CH}), 6.91-7.18(\mathrm{~m}, 18 \mathrm{H}, \mathrm{Ar}-\mathrm{H}), 6.62-6.87$ (m, 13H, Ar-H), 5.79-6.52 (m, 7H, Ar-H, C=CH), 3.94-4.21 (m, 4H, CH 2$), 3.80-3.92\left(\mathrm{~m}, 8 \mathrm{H}, \mathrm{OCH}_{3}, 0.5 \times \mathrm{CH}_{2}\right), 3.75\left(\mathrm{~s}, 2 \mathrm{H}, \mathrm{CH}_{2}\right), 3.03-3.34(\mathrm{~m}, 6 \mathrm{H}$, $\left.\mathrm{NCH}_{3}\right), 2.45\left(\mathrm{~m}, 4 \mathrm{H}, \mathrm{CH}_{2}\right), 0.90\left(\mathrm{t}, J=7.04 \mathrm{~Hz}, 6 \mathrm{H}, \mathrm{CH}_{3}\right) .{ }^{13} \mathrm{C}-\mathrm{NMR}\left(\mathrm{CDCl}_{3}\right) \delta 171.3(\mathrm{C}=\mathrm{O}), 167.2,167.2$, 157.2, 156.3, 155.0, 154.1, 148.2, 145.8, 143.0, 142.7, 142.6, 140.9, 140.8, 137.8, 136.6, 136.2, 135.7, 135.3, 132.0, 132.0, 130.7, 130.6, 129.7, 128.7, 127.8, 125.8, 121.9, 121.6, 115.4, 115.1, 114.3, 113.9, 113.1, 112.6, 112.6, 110.5, 66.8, 66.5, $60.4\left(\mathrm{CH}_{2}\right), 56.0\left(\mathrm{OCH}_{3}\right), 48.6,37.7\left(\mathrm{NCH}_{3}\right), 35.1\left(\mathrm{NCH}_{3}\right), 29.01\left(\mathrm{CH}_{2}\right), 28.99$ $\left(\mathrm{CH}_{2}\right), 13.6\left(\mathrm{CH}_{3}\right)$. IR: $v_{\max }(\mathrm{KBr}) \mathrm{cm}^{-1}: 3385.2,2930.3,1733.5,1643.5,1584.1,1504.9,1265.0,1238.0$, 1025.7, 834.0. HRMS (EI): Found 572.2413 [M + Na] ${ }^{+}, \mathrm{C}_{35} \mathrm{H}_{35} \mathrm{NO}_{5} \mathrm{Na}$ requires 572.2413.

(E/Z)-3-(3-hydroxy-4-methoxyphenyl)-N-(2-(4-(1-(4-hydroxyphenyl)-2-phenylbut-1-en-1-yl)phenoxy)ethyl)-Nmethylpropanamide (5b). Following the general method above, the 3-phenylpropanoic acid $4 \mathbf{b}$ (1.2 eq., $96.5 \mathrm{mg}, 0.492 \mathrm{mmol})$, EDC (1.4 eq., $110 \mathrm{mg}, 0.572 \mathrm{mmol}$ ) and HOBt (1.4 eq., $77.6 \mathrm{mg}, 0.572 \mathrm{mmol}$ ) was reacted with endoxifen derivative $2 \mathbf{a}$ (1 eq., $200 \mathrm{mg}, 0.41 \mathrm{mmol})$. Purification by flash chromatography over silica gel (DCM:EtOAc, gradient 20:1 to 10:1) afforded the product as a white solid. (234 mg, 86\%). HRMS: Found $688.3438[\mathrm{M}+\mathrm{Na}]^{+}, \mathrm{C}_{41} \mathrm{H}_{51} \mathrm{NO}_{5} \mathrm{NaSi}$ requires 688.3434. The silyl ether $(144 \mathrm{mg}, 0.219$ $\mathrm{mmol}$ ) was dissolved in THF ( $3 \mathrm{~mL}$ ) and stirred under nitrogen. A solution of TBAF (1M in THF, 1 eq., $0.219 \mathrm{~mL}, 0.219 \mathrm{mmol}$ ) was added to the mixture and stirred for $1 \mathrm{~h}$. The solvent was evaporated and the material was purified via flash chromatography over silica gel (DCM:EtOAc, gradient 6:1 to 3:1) to afford the product as a white solid. (108 mg, 90\%), m.p. 78-80 ${ }^{\circ} \mathrm{C}$. (DCM:EtOAc). ${ }^{1} \mathrm{H}-\mathrm{NMR}\left(\mathrm{CDCl}_{3}\right) \delta$ 7.01-7.20 (m, 12H, Ar-H), 5.57-6.86 (m, 20H, Ar-H), 3.50-4.17 (m, 13H, OCH, $\left.\mathrm{CH}_{2}\right), 2.40-3.09$ (m, 
$\left.18 \mathrm{H}, \mathrm{NCH}_{3}, \mathrm{CH}_{2}\right), 0.75-0.98\left(\mathrm{~m}, 6 \mathrm{H}, \mathrm{CH}_{3}\right) .{ }^{13} \mathrm{C}-\mathrm{NMR}\left(\mathrm{CDCl}_{3}\right) \delta 172.91(\mathrm{C}=\mathrm{O}), 172.85(\mathrm{C}=\mathrm{O}), 157.2$, $156.3,156.0,154.9,154.0,145.5,145.5,145.5,145.0,145.0,142.7,142.6,141.0,140.9,137.8,137.8,136.6$, 136.1, 135.8, 135.7, 135.4, 134.4, 134.4, 132.0, 132.0, 131.9, 130.7, 130.6, 130.6, 129.7, 127.8, 127.8, 125.9, $119.8,119.8,115.0,114.5,114.5,114.3,113.9,113.1,113.1,110.7,110.7,66.6\left(\mathrm{CH}_{2}\right), 66.3\left(\mathrm{CH}_{2}\right), 64.9\left(\mathrm{CH}_{2}\right)$, $60.4\left(\mathrm{CH}_{2}\right), 55.9\left(\mathrm{OCH}_{3}\right), 49.1\left(\mathrm{CH}_{2}\right), 48.2\left(\mathrm{CH}_{2}\right), 48.1\left(\mathrm{CH}_{2}\right), 37.6\left(\mathrm{NCH}_{3}\right), 37.5\left(\mathrm{NCH}_{3}\right), 35.6\left(\mathrm{CH}_{2}\right)$, $35.5\left(\mathrm{CH}_{2}\right), 35.1\left(\mathrm{CH}_{2}\right), 35.0\left(\mathrm{CH}_{2}\right), 34.2,34.1,31.0\left(\mathrm{CH}_{2}\right), 30.7\left(\mathrm{CH}_{2}\right), 30.6\left(\mathrm{CH}_{2}\right), 29.0\left(\mathrm{CH}_{2}\right), 28.98$ $\left(\mathrm{CH}_{2}\right), 13.6\left(\mathrm{CH}_{3}\right), 13.6\left(\mathrm{CH}_{3}\right)$. IR: $v_{\max }(\mathrm{KBr}) \mathrm{cm}^{-1}: 3441.1,3232.4,2931.4,1733.5,1607.4,1508.4,1272.0$, 1239.5, 1029.1, 834.8. HRMS (EI): Found 574.2565 [M + Na $]^{+}, \mathrm{C}_{35} \mathrm{H}_{37} \mathrm{NO}_{5} \mathrm{Na}$ requires 574.2569.

(E/Z)-N-(2-(4-((Z)-1-(4-Hydroxyphenyl)-2-phenylbut-1-en-1-yl)phenoxy)ethyl)-N-methyl-3-(3,4,5-trimethoxyphenyl)acrylamide (5c). Following the general method above, the cinnamic acid 4c (1.2 eq., $117 \mathrm{mg}, 0.492 \mathrm{mmol})$, EDC (1.4 eq., $110 \mathrm{mg}, 0.572 \mathrm{mmol}$ ) and HOBt (1.4 eq., $77.6 \mathrm{mg}, 0.572 \mathrm{mmol})$ was reacted with endoxifen derivative $2 \mathbf{a}$ (1 eq., $200 \mathrm{mg}, 0.41 \mathrm{mmol})$. Purification by flash chromatography over silica gel (DCM:EtOAc, gradient 20:1 to 10:1) afforded the product as a white solid, (258 $\mathrm{mg}, 89 \%)$. HRMS: Found $730.3569[\mathrm{M}+\mathrm{Na}]^{+}, \mathrm{C}_{43} \mathrm{H}_{53} \mathrm{NO}_{6} \mathrm{NaSi}$ requires 730.3540 . The silyl ether $(160 \mathrm{mg}, 0.226$ $\mathrm{mmol}$ ) was dissolved in THF ( $3 \mathrm{~mL}$ ) and stirred under nitrogen. A solution of TBAF (1 M in THF, 1 eq., $0.226 \mathrm{~mL}, 0.226 \mathrm{mmol}$ ) was added to the mixture stirred for $1 \mathrm{~h}$. The solvent was evaporated under reduced pressure. The material was purified via flash chromatography over silica gel (DCM:EtOAc, gradient $6: 1$ to $3: 1$ ) to afford the product as a white solid. (127 mg, 95\%), m.p: 66-68 ${ }^{\circ} \mathrm{C} .{ }^{1} \mathrm{H}-\mathrm{NMR}$ $\left(\mathrm{CDCl}_{3}\right) \delta 7.53-7.65(\mathrm{~m}, 2 \mathrm{H}, \mathrm{C}=\mathrm{CH}), 7.01-7.20(\mathrm{~m}, 14 \mathrm{H}, \mathrm{Ar}-\mathrm{H}), 6.43-6.89$ (m, 18H, Ar-H, C=CH), 3.96-4.25 (m, 4H, CH 2$), 3.74-3.95\left(\mathrm{~m}, 22 \mathrm{H}, \mathrm{OCH}_{3}, \mathrm{CH}_{2}\right), 3.04-3.39\left(\mathrm{~m}, 6 \mathrm{H}, \mathrm{CH}_{3}\right), 2.46(\mathrm{q}, \mathrm{J}=7.04$ $\left.\mathrm{Hz}, 4 \mathrm{H}, \mathrm{CH}_{2}\right), 0.84-0.98\left(\mathrm{~m}, 6 \mathrm{H}, \mathrm{CH}_{3}\right), \mathrm{OH}$ not observed. ${ }^{13} \mathrm{C}-\mathrm{NMR}\left(\mathrm{CDCl}_{3}\right), \delta 169.6(\mathrm{C}=\mathrm{O}), 153.4$, 153.3, 132.0, 130.7, 129.7, 127.8, 125.9, 116.4, 115.0, 114.3, 113.9, 113.1, 105.4, 105.1, $60.9\left(\mathrm{CH}_{2}\right), 60.4$ $\left(\mathrm{OCH}_{3}\right), 56.2\left(\mathrm{OCH}_{3}\right), 56.2\left(\mathrm{OCH}_{3}\right), 37.9\left(\mathrm{NCH}_{3}\right), 29.0\left(\mathrm{CH}_{2}\right), 13.6\left(\mathrm{CH}_{3}\right) \mathrm{IR}: v_{\max }(\mathrm{KBr}) \mathrm{cm}^{-1}: 3236.4$, 2934.8, 1735.4, 1647.2, 1583.3, 1506.3, 1240.5, 1089.3, 825.9. HRMS (EI): Found 616.2691 [M + Na] ${ }^{+}$, $\mathrm{C}_{37} \mathrm{H}_{39} \mathrm{NO}_{6} \mathrm{Na}$ requires 616.2675 .

N-(2-(4-((E/Z)-1-(4-Hydroxyphenyl)-2-phenylbut-1-enyl)phenoxy)ethyl)-3-(3,4,5-trimethoxyphenyl)-Nmethylpropanamide (5d). (i) Following the general method above, the cinnamic acid/3-phenylpropanoic acid analogue $4 \mathrm{~d}$ was reacted with endoxifen derivative $2 \mathrm{a}$. The crude mixture was then taken to the next step without further purification. The final product was purified via flash chromatography over silica gel (DCM:EtOAc, gradient 6:1 to 3:1) to afford the product as a brown resin (29\%). (ii) As per general method, the 3-phenylpropanoic acid $4 \mathrm{~d}$ (1.2 eq., $118 \mathrm{mg}, 0.492 \mathrm{mmol})$, EDC (1.4 eq., $110 \mathrm{mg}$, $0.572 \mathrm{mmol}$ ), and HOBt (1.4 eq., $77.6 \mathrm{mg}, 0.572 \mathrm{mmol})$ was reacted with endoxifen $2 \mathrm{a}(1 \mathrm{eq} ., 200 \mathrm{mg}$, $0.41 \mathrm{mmol})$. The crude product was afforded as a brown resin. The material was purified via flash chromatography over silica gel (DCM:EtOAc, gradient 20:1 to 10:1) to afford the product as a white solid. (264 mg, 92\%). HRMS: Found $732.3723[\mathrm{M}+\mathrm{Na}]^{+}, \mathrm{C}_{43} \mathrm{H}_{55} \mathrm{NO}_{6} \mathrm{NaSi}$ requires 732.3696. The product was then deprotected. The protected compound (156 mg, $0.22 \mathrm{mmol}$ ) was dissolved in THF ( $3 \mathrm{~mL}$ ) and stirred under nitrogen environment. A solution of TBAF (1 M in THF, 1 eq., $0.22 \mathrm{~mL}$, $0.22 \mathrm{mmol}$ ) was added to the mixture and allowed to stir for $1 \mathrm{~h}$. The mixture was evaporated to dryness under reduced pressure. The material was purified via flash chromatography over silica gel (DCM:EtOAc, gradient 6:1 to 3:1) to afford the product as a white solid. (121 mg, 93\%), m.p. $73-75^{\circ} \mathrm{C}$. ${ }^{1} \mathrm{H}-\mathrm{NMR}\left(\mathrm{CDCl}_{3}\right)$ : $\delta$ 7.18-6.40 (m, $\left.15 \mathrm{H}, \mathrm{Ar}-\mathrm{H}\right), 4.20-4.13\left(\mathrm{~m}, 1 \mathrm{H}, \mathrm{CH}_{2}-\mathrm{O}-\right), 4.05-3.97\left(\mathrm{~m}, 1 \mathrm{H},-\mathrm{OCH}_{2} \mathrm{O}-\right)$, 3.85-3.83 (m, 9H, OCH $\mathrm{OCH}_{3}, 3.79-3.77\left(\mathrm{~m}, 1 \mathrm{H}, \mathrm{CH}_{2}-\mathrm{NCH}_{3}\right), 3.70-3.66\left(\mathrm{~m}, 1 \mathrm{H}, \mathrm{CH}_{2}-\mathrm{NCH}_{3}\right), 3.11(\mathrm{~s}, 1 \mathrm{H}$, $\left.\mathrm{NCH}_{3}\right), 3.08\left(\mathrm{~s}, 1 \mathrm{H}, \mathrm{NCH}_{3}\right), 3.00\left(\mathrm{~s}, 0.5 \mathrm{H}, \mathrm{NCH}_{3}\right), 2.99\left(\mathrm{~s}, 0.5 \mathrm{H}, \mathrm{NCH}_{3}\right), 2.92\left(\mathrm{~m}, 2 \mathrm{H}, \mathrm{Ar}-\mathrm{CH}_{2}\right), 2.80-2.58$ $\left(\mathrm{m}, 2 \mathrm{H},-\mathrm{O}-\mathrm{CH}_{2}\right), 2.52-2.48\left(\mathrm{~m}, 2 \mathrm{H}, \mathrm{CH}_{2}-\mathrm{CH}_{3}\right), 0.95\left(\mathrm{t}, 3 \mathrm{H}, 7.5 \mathrm{~Hz}, \mathrm{CH}_{3}\right), \mathrm{OH}$ not observed. ${ }^{13} \mathrm{C}-\mathrm{NMR}$ $\left(\mathrm{CDCl}_{3}\right): \delta 170.27(\mathrm{C}=\mathrm{O}), 156.75,154.48,152.11,143.74,142.31,140.93,137.36,137.54,136.15,134.91$, $133.88,131.60,131.40,130.23,130.19,129.26,127.38,125.45,119.39,114.59,144.10,113.90,113.42,112.07$, 110.25, $66.18\left(\mathrm{OCH}_{2}\right), 65.88\left(\mathrm{OCH}_{2}\right), 56.88\left(\mathrm{OCH}_{3}\right), 55.64\left(\mathrm{OCH}_{3}\right), 55.50\left(\mathrm{OCH}_{3}\right), 53.01,47.74\left(\mathrm{CH}_{2}\right)$, 37.24 $\left(\mathrm{CH}_{3} \mathrm{~N}\right), 37.18\left(\mathrm{CH}_{3} \mathrm{~N}\right), 35.17\left(\mathrm{CH}_{2} \mathrm{O}\right), 35.42\left(\mathrm{OCH}_{2}\right), 33.86\left(\mathrm{CH}_{3} \mathrm{~N}\right), 30.73\left(\mathrm{CH}_{2}\right), 30.52\left(\mathrm{CH}_{2}\right)$, 
$28.46\left(\mathrm{CH}_{2} \mathrm{CH}_{3}\right), 13.60\left(\mathrm{CH}_{3}\right), 13.17\left(\mathrm{CH}_{3}\right) . \mathrm{IR}: v_{\max }(\mathrm{KBr}) \mathrm{cm}^{-1}: 3251.9,2933.8,1735.3,1607.2,1589.8$, 1508.4, 1239.2, 1127.4, 833.7. HRMS (EI): Found 618.2691 [M+ Na] ${ }^{+}, \mathrm{C}_{37} \mathrm{H}_{41} \mathrm{NO}_{6} \mathrm{Na}$ requires 618.2691.

[4-(tert-Butyldimethylsilanyloxy)phenyl]-(4-hydroxyphenyl)methanone (7a). 4,4'-Dihydroxybenzo-phenone $(6,6.00 \mathrm{~g}, 28 \mathrm{mmol})$ and imidazole $(2.094 \mathrm{~g}, 31 \mathrm{mmol})$ were dissolved in DMF $(20 \mathrm{~mL})$ with stirring. A solution of tert-butyldimethylsilyl chloride $(4.22 \mathrm{~g}, 28 \mathrm{mmol})$ in DMF $(20 \mathrm{~mL})$ was added to the mixture over $1 \mathrm{~h}$. The reaction mixture was allowed to stir at room temperature for $16 \mathrm{~h}$ followed by the addition of ethyl acetate $(100 \mathrm{~mL})$ and $10 \%$ hydrochloric acid $(50 \mathrm{~mL})$. The organic layer was washed with water $(100 \mathrm{~mL})$, brine $(100 \mathrm{~mL})$, dried over sodium sulphate and evaporated to dryness in vacuo to yield crude product. The material was purified via flash chromatography on silica gel ( $n$-hexane:DCM, 5:1) to afford the product $7 \mathrm{a}$ as a light yellow oil. $(3.34 \mathrm{~g}, 27 \%) .{ }^{1} \mathrm{H}-\mathrm{NMR}\left(\mathrm{CDCl}_{3}\right): \delta$ $7.76(\mathrm{dd}, 4 \mathrm{H}, J=6.5 \mathrm{~Hz}, \mathrm{Ar}-\mathrm{H}), 6.94(\mathrm{dd}, 4 \mathrm{H}, J=7.5 \mathrm{~Hz}, \mathrm{Ar}-\mathrm{H}), 1.02\left(\mathrm{~s}, 9 \mathrm{H}, \mathrm{CH}_{3}\right), 0.27\left(\mathrm{~s}, 6 \mathrm{H}, \mathrm{CH}_{3}\right)$. ${ }^{13} \mathrm{C}-\mathrm{NMR}\left(\mathrm{CDCl}_{3}\right): \delta 195.66,160.25,159.47,132.41,132.02,130.50,129.37,119.30,114.90,25.16\left(\mathrm{CH}_{3}\right)$, $17.80,-4.78(\mathrm{SiC})$. IR: $v_{\max }(\mathrm{KBr}) \mathrm{cm}^{-1}: 3362.6,295.9,2930.0,2856.9,1641.6,1602.3,1580.3,1508.1$, 1470.5, 1313.0, 1278.1, 1161.1, 913.4, 839.1, 771.9. HRMS (EI): Found $329.1579[\mathrm{M}+\mathrm{H}]^{+}, \mathrm{C}_{19} \mathrm{H}_{25} \mathrm{O}_{3} \mathrm{Si}$ requires 329.1573. The diprotected benzophenone bis(4-((tert-butyldimethylsilyl)oxy)phenyl)methanone was also obtained as a colourless oil (34\%). ${ }^{1} \mathrm{H}-\mathrm{NMR}\left(\mathrm{CDCl}_{3}\right): \delta 7.75(\mathrm{~d}, 4 \mathrm{H}, J=8.5 \mathrm{~Hz}, \mathrm{Ar}-\mathrm{H}), 6.91$ $(\mathrm{d}, 4 \mathrm{H}, J=8.5 \mathrm{~Hz}, \mathrm{Ar}-\mathrm{H}), 1.02\left(\mathrm{~s}, 18 \mathrm{H}, \mathrm{CH}_{3}\right), 0.26\left(\mathrm{~s}, 12 \mathrm{H}, \mathrm{CH}_{3}\right) .{ }^{13} \mathrm{C}-\mathrm{NMR}\left(\mathrm{CDCl}_{3}\right): \delta 194.1(\mathrm{C}=\mathrm{O})$, 159.0, 131.7, 130.8, 119.2, 119.1, $25.2\left(\mathrm{CH}_{2}\right), 17.8,-4.79$ (SiC) IR: $v_{\max }$ (Film) $\mathrm{cm}^{-1}: 2956.0,2930.8,2886.7$, 2858.8, 1653.1, 1599.1, 1508.0, 1267.5, 1161.2, 1006.4, 909.2. HRMS (EI): Found 437.1937 [M + Na] ${ }^{+}$, $\mathrm{C}_{23} \mathrm{H}_{34} \mathrm{O}_{3} \mathrm{Si}_{2} \mathrm{Na}$ requires 437.1944.

\subsubsection{General Method for Cyclofenil Derivatives 8a-8e via McMurry Coupling}

Titanium tetrachloride ( 4.5 eq., $5.2 \mathrm{~g}, 37.4 \mathrm{mmol}, 3 \mathrm{~mL}$ ) was added via a syringe dropwise to zinc dust (9 eq., $3.58 \mathrm{~g}, 54.81 \mathrm{mmol})$ in dry THF $(50 \mathrm{~mL})$ and the mixture was refluxed for $2 \mathrm{~h}$ in darkness and under nitrogen. The appropriate phenolic ketone $7 \mathbf{a}$ (1 eq.) and cyclic ketone ( 3 eq.) were dissolved in dry THF $(40 \mathrm{~mL})$. This solution was added to the titanium tetrachloride/zinc mixture carefully via a syringe. The reaction mixture was then refluxed for a further $3 \mathrm{~h}$. and then cooled and then diluted with EtOAc $(75 \mathrm{~mL})$ and $10 \% \mathrm{~K}_{2} \mathrm{CO}_{3}$ solution. The mixture was filtered under vacuum and the aqueous layer was extracted with EtOAc $(3 \times 50 \mathrm{~mL})$. The combined organic layers were washed with $10 \% \mathrm{~K}_{2} \mathrm{CO}_{3}$ solution $(20 \mathrm{~mL})$, water $(50 \mathrm{~mL})$ and brine $(50 \mathrm{~mL})$ then dried over $\mathrm{Na}_{2} \mathrm{SO}_{4}$, filtered and the solvent was evaporated under reduced pressure to afford the crude product. The material was purified via flash chromatography over silica gel to afford the product.

4-((4-((tert-Butyldimethylsilyl)oxy)phenyl)(cyclopentylidene)methyl)phenol (8a). Following the general method above, using, $\mathrm{TiCl}_{4}$ (4.5 eq., $5.2 \mathrm{~g}, 27.4 \mathrm{mmol}, 3 \mathrm{~mL}$ ), $\mathrm{Zn}$ dust (9 eq., $3.58 \mathrm{~g}, 54.81 \mathrm{mmol}$ ), $7 \mathrm{a}$ ( 1 eq., $2 \mathrm{~g}, 6.09 \mathrm{mmol}$ ) and cyclopentanone ( 3 eq., $1.54 \mathrm{~g}, 18.26 \mathrm{mmol}, 1.88 \mathrm{~mL}$ ). The crude material was purified via flash chromatography over silica gel ( $n$-hexane:DCM, 3:1) to afford the product as an orange resin $(2.25 \mathrm{~g}, 97 \%) .{ }^{1} \mathrm{H}-\mathrm{NMR}\left(\mathrm{CDCl}_{3}\right) \delta 7.01-7.11(\mathrm{~m}, 4 \mathrm{H},(\mathrm{Ar}-\mathrm{H})), 6.74-6.82(\mathrm{~m}, 4 \mathrm{H},(\mathrm{Ar}-\mathrm{H}))$, $2.40\left(\mathrm{t}, J=7.00 \mathrm{~Hz}, 4 \mathrm{H},\left(2 \times \mathrm{CH}_{2}\right)\right), 1.69$ (quin, $\left.J=3.50 \mathrm{~Hz}, 4 \mathrm{H},\left(2 \times \mathrm{CH}_{2}\right)\right), 1.01\left(\mathrm{~s}, 9 \mathrm{H},\left(3 \times \mathrm{CH}_{3}\right)\right)$, $0.22\left(\mathrm{~s}, 6 \mathrm{H},\left(2 \times \mathrm{CH}_{3}\right)\right) .{ }^{13} \mathrm{C}-\mathrm{NMR}\left(\mathrm{CDCl}_{3}\right) \delta 153.4,153.1,141.6,136.4,135.7,131.5,130.0,129.7,118.9$,

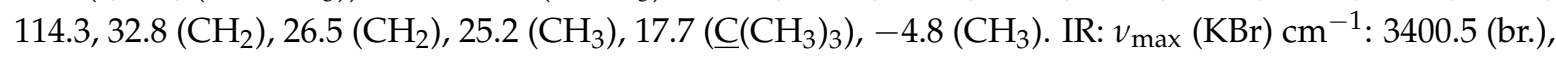
2955.5, 2930.6, 2358.3, 1635.33, 1598.3, 1507.4, 1270.0 (br.), 1163.4, 911.7. HRMS (EI): Found 379.2101 $[\mathrm{M}-\mathrm{H}]^{-}, \mathrm{C}_{24} \mathrm{H}_{31} \mathrm{O}_{2} \mathrm{Si}$ requires 379.2093.

4-((4-((tert-Butyldimethylsilyl)oxy)phenyl)(cyclohexaneylidene) methyl) phenol (8b). Following the general method above, $\mathrm{TiCl}_{4}$ (4.5 eq., $5.2 \mathrm{~g}, 27.4 \mathrm{mmol}, 3 \mathrm{~mL}$ ), Zn dust (9 eq., $3.58 \mathrm{~g}, 54.81 \mathrm{mmol}$ ), $7 \mathrm{a}$ (1 eq., $2 \mathrm{~g}, 6.09 \mathrm{mmol}$ ) and cyclohexaneanone ( 3 eq., $1.79 \mathrm{~g}, 18.26 \mathrm{mmol}, 1.9 \mathrm{~mL}$ ) were reacted. The crude material was purified via flash chromatography over silica gel (n-Hexane:DCM, 3:1) to afford the product as an orange resin $(2.1 \mathrm{~g}, 87 \%) .{ }^{1} \mathrm{H}-\mathrm{NMR}\left(\mathrm{CDCl}_{3}\right) \delta 6.95-7.04(\mathrm{~m}, 4 \mathrm{H}, \mathrm{Ar}-\mathrm{H}), 6.74-6.79(\mathrm{~m}, 4 \mathrm{H}$, Ar-H), 2.23-2.31 (m, 4H, $\left.2 \times \mathrm{CH}_{2}\right), 1.55-1.69\left(\mathrm{~m}, 6 \mathrm{H}, 3 \times \mathrm{CH}_{2}\right), 1.02\left(\mathrm{~s}, 9 \mathrm{H}, 3 \times \mathrm{CH}_{3}\right), 0.24(\mathrm{~s}, 6 \mathrm{H}$, $\left.2 \times \mathrm{CH}_{3}\right) .{ }^{13} \mathrm{C}-\mathrm{NMR}\left(\mathrm{CDCl}_{3}\right) \delta 153.3,153.2,137.8,136.0,135.6,133.1,130.7,130.4,118.8,114.2,32.1$ 


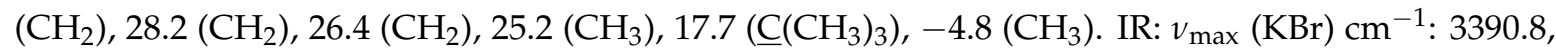
2928.4, 2855.8, 1698.7, 1604.9, 1505.7, 1471, 1463.2, 1447.1, 1258.7, 1167.1, 1099.0, 915.8, 802.1. HRMS (EI): Found $395.2405[\mathrm{M}+\mathrm{H}]^{+}, \mathrm{C}_{25} \mathrm{H}_{35} \mathrm{O}_{2} \mathrm{Si}$ requires 395.2406.

4-((4-((tert-Butyldimethylsilyl)oxy)phenyl)(cycloheptylidene)methyl)phenol (8c). Following the general method above, $\mathrm{TiCl}_{4}$ ( 4.5 eq., $\left.5.2 \mathrm{~g}, 27.4 \mathrm{mmol}, 3 \mathrm{~mL}\right)$, Zn dust $(9$ eq., $3.58 \mathrm{~g}, 54.81 \mathrm{mmol}), 7 \mathrm{a}$ (1 eq., $2 \mathrm{~g}$, $6.09 \mathrm{mmol}$ ) and cycloheptanone (3 eq., $2.04 \mathrm{~g}, 18.26 \mathrm{mmol}, 2.15 \mathrm{~mL}$ ) were reacted. The crude material was purified via flash chromatography over silica gel (n-hexane:DCM, 3:1) to afford the product as an orange resin $(2.1 \mathrm{~g}, 84 \%) .{ }^{1} \mathrm{H}-\mathrm{NMR}\left(\mathrm{CDCl}_{3}\right) \delta 6.99-7.06(\mathrm{~m}, 4 \mathrm{H}, \mathrm{Ar}-\mathrm{H}), 6.73-6.79(\mathrm{~m}, 4 \mathrm{H}, \mathrm{Ar}-\mathrm{H}), 2.33(\mathrm{~s}$, $\left.4 \mathrm{H}, 2 \times \mathrm{CH}_{2}\right), 1.59\left(\mathrm{~s}, 8 \mathrm{H}, 4 \times \mathrm{CH}_{2}\right), 1.00\left(\mathrm{~s}, 9 \mathrm{H}, 3 \times \mathrm{CH}_{3}\right), 0.21\left(\mathrm{~s}, 6 \mathrm{H}, 2 \times \mathrm{CH}_{3}\right) .{ }^{13} \mathrm{C}-\mathrm{NMR}\left(\mathrm{CDCl}_{3}\right) \delta$ 153.1, 139.1, 136.4, 136.1, 135.8, 130.1, 129.9, 118.9, 114.3, $33.0\left(\mathrm{CH}_{2}\right), 32.96\left(\mathrm{CH}_{2}\right), 29.0\left(\mathrm{CH}_{2}\right), 27.7\left(\mathrm{CH}_{2}\right)$, $25.2\left(\mathrm{CH}_{3}\right), 17.7\left(\underline{\mathrm{C}}\left(\mathrm{CH}_{3}\right)_{3}\right),-4.8\left(\mathrm{CH}_{3}\right) . \mathrm{IR}: v_{\max }(\mathrm{KBr}) \mathrm{cm}^{-1}: 3401.2,2929.5,2857.5,1647.7,1599.7$, 1507.2, 1462.9, 1268.2, 1163.6, 1013.5, 912.9, 840.0, 805.4, 781.4. HRMS (EI): Found 409.2574 [M + H] $]^{+}$, $\mathrm{C}_{26} \mathrm{H}_{37} \mathrm{O}_{2} \mathrm{Si}$ requires 409.2563 .

4-((4-((tert-Butyldimethylsilyl)oxy)phenyl)(cyclooctylidene)methyl)phenol (8d). Following the general method above, $\mathrm{TiCl}_{4}$ (4.5 eq., $\left.5.2 \mathrm{~g}, 27.4 \mathrm{mmol}, 3 \mathrm{~mL}\right), \mathrm{Zn}$ dust $(9$ eq., $3.58 \mathrm{~g}, 54.81 \mathrm{mmol}), 7 \mathrm{a}$ (1 eq., $2 \mathrm{~g}$, $6.09 \mathrm{mmol}$ ) and cyclooctanone ( $3 \mathrm{eq} ., 2.30 \mathrm{~g}, 18.26 \mathrm{mmol}, 2.4 \mathrm{~mL}$ ) were reacted. The crude material was purified via flash chromatography over silica gel ( $n$-Hexane:DCM, 3:1) to afford the product as an orange resign $(2.3 \mathrm{~g}, 89 \%) .{ }^{1} \mathrm{H}-\mathrm{NMR}\left(\mathrm{CDCl}_{3}\right) . \delta 6.99-7.11(\mathrm{~m}, 4 \mathrm{H}, \mathrm{Ar}-\mathrm{H}), 6.73-6.80(\mathrm{~m}, 4 \mathrm{H}, \mathrm{Ar}-\mathrm{H}), 2.28$ $\left(\mathrm{t}, J=6.50 \mathrm{~Hz}, 4 \mathrm{H}, 2 \times \mathrm{CH}_{2}\right), 1.63-1.71\left(\mathrm{~m}, 2 \mathrm{H}, \mathrm{CH}_{2}\right), 1.47-1.62\left(\mathrm{~m}, 8 \mathrm{H}, 4 \times \mathrm{CH}_{2}\right), 0.99\left(\mathrm{~s}, 9 \mathrm{H}, 3 \times \mathrm{CH}_{3}\right)$, $0.21\left(\mathrm{~s}, 6 \mathrm{H}, 2 \times \mathrm{CH}_{3}\right) .{ }^{13} \mathrm{C}-\mathrm{NMR}\left(\mathrm{CDCl}_{3}\right) \delta 153.1,139.4,136.7,136.3,135.8,129.8,129.5,119.1,114.4$, $32.0\left(\mathrm{CH}_{2}\right), 26.1\left(\mathrm{CH}_{2}\right), 25.9\left(\mathrm{CH}_{2}\right), 25.8\left(\mathrm{CH}_{2}\right), 25.2\left(\mathrm{CH}_{3}\right), 17.7\left(\underline{\mathrm{C}}\left(\mathrm{CH}_{3}\right)_{3}\right),-4.9\left(\mathrm{CH}_{3}\right) . \mathrm{IR}: v_{\max }(\mathrm{KBr})$ $\mathrm{cm}^{-1}$ : 3345.2 (br.), 2928.7, 2856.5, 1603.4, 1503.5, 1253.8 (br.), 1166.7, 917.0. HRMS (EI): Found 445.2519 $[\mathrm{M}+\mathrm{Na}]^{+}, \mathrm{C}_{27} \mathrm{H}_{38} \mathrm{NaO}_{2} \mathrm{Si}$ requires 455.2539.

4-((4-((tert-Butyldimethylsilyl)oxy)phenyl)(4-methylcyclohexaneylidene) methyl) phenol (8e). Following the general method above, $\mathrm{TiCl}_{4}$ ( 4.5 eq., $5.2 \mathrm{~g}, 27.4 \mathrm{mmol}, 3 \mathrm{~mL}$ ), Zn dust (9 eq., $\left.3.58 \mathrm{~g}, 54.81 \mathrm{mmol}\right), 7 \mathbf{a}(1$ eq., $2 \mathrm{~g}, 6.09 \mathrm{mmol}$ ) and 4-methylcyclohexaneanone (3 eq., $2.05 \mathrm{~g}$, $18.27 \mathrm{mmol}, 2.24 \mathrm{~mL}$ ) were reacted. The crude material was purified via flash chromatography over silica gel ( $n$-Hexane:DCM, 3:1) to afford the product as an orange resin $(2.15 \mathrm{~g}, 86 \%) .{ }^{1} \mathrm{H}-\mathrm{NMR}\left(\mathrm{CDCl}_{3}\right) \delta 7.04-7.08(\mathrm{~m}, 4 \mathrm{H}, \mathrm{Ar}-\mathrm{H}), 6.80-6.86$ $(\mathrm{m}, 4 \mathrm{H}, \mathrm{Ar}-\mathrm{H}), 2.69\left(\mathrm{~d}, J=13.1 \mathrm{~Hz}, 4 \mathrm{H}, 2 \times \mathrm{CH}_{2}\right), 2.05\left(\mathrm{~m}, 5 \mathrm{H}, \mathrm{CH}, 2 \times \mathrm{CH}_{2}\right), 1.09\left(\mathrm{~s}, 9 \mathrm{H}, 3 \times \mathrm{CH}_{3}\right)$, $1.02\left(\mathrm{~d}, 3 \mathrm{H}, \mathrm{J}=6.5 \mathrm{~Hz}, \mathrm{CH}_{3}\right), 0.30\left(\mathrm{~s}, 6 \mathrm{H}, 2 \times \mathrm{CH}_{3}\right) .{ }^{13} \mathrm{C}-\mathrm{NMR}\left(\mathrm{CDCl}_{3}\right) \delta 153.4,153.3,137.4,136.2$, 135.6, 133.3, 130.7, 130.5, 118.9, 114.4, $32.4(\mathrm{CH}), 29.0\left(\mathrm{CH}_{2}\right), 26.6\left(\mathrm{CH}_{2}\right), 25.2\left(\mathrm{CH}_{3}\right), 17.8\left(\underline{\mathrm{C}}\left(\mathrm{CH}_{3}\right)_{3}\right)$, $-4.7\left(\mathrm{CH}_{3}\right)$. IR: $v_{\max }(\mathrm{KBr}) \mathrm{cm}^{-1}: 3369.1,3031.2,2919.0,2855.1,1704.1,1603.2 .1505 .4,1471.7,1362.1$, 1253.0, 1167.5, 1099.6, 1007.4, 916.0839, 780.7, 734.2. HRMS (EI): Found 409.2570 [M + H] ${ }^{+}, \mathrm{C}_{26} \mathrm{H}_{37} \mathrm{O}_{2} \mathrm{Si}$ requires 409.2563 .

\subsubsection{General Method for the Preparation of Bromoethyl Ethers 9a-9e}

The appropriate phenol 8a-8e (1 eq.) was dissolved in 1,2-dibromoethane ( 50 eq.) with stirring. Tetrabutylammonium hydrogen sulfate $(5 \mathrm{mmol})$ was added followed by $1 \mathrm{M} \mathrm{NaOH}$ solution $(50 \mathrm{~mL})$. The biphasic mixture was stirred vigorously at room temperature for $16 \mathrm{~h}$. followed by addition of DCM $(100 \mathrm{~mL})$ and $\mathrm{NaHCO}_{3}$ solution $(100 \mathrm{~mL})$. The aqueous layer was extracted with $\mathrm{DCM}$ $(2 \times 100 \mathrm{~mL})$ and the organic extracts were combined and washed with water $(50 \mathrm{~mL})$, brine $(50 \mathrm{~mL})$ and dried over $\mathrm{Na}_{2} \mathrm{SO}_{4}$. The solvent was evaporated under reduced pressure, and the residue was purified via flash chromatography over silica gel (eluent: DCM:n-hexane) to afford the product.

(4-((4-(2-Bromoethoxy)phenyl)(cyclopentylidene)methyl)phenoxy)(tert-butyl) dimethylsilane (9a). Following the general method above, phenol $8 \mathrm{a}$ (1 eq., $2.1 \mathrm{~g}, 5.52 \mathrm{mmol}), 1,2$-dibromoethane ( 50 eq. $52.29 \mathrm{~g}$, $275.8 \mathrm{mmol}, 24 \mathrm{~mL})$ and tetrabutylammonium hydrogen sulfate $(1.7 \mathrm{~g}, 5 \mathrm{mmol})$ were reacted. The crude product was purified via flash chromatography over silica gel (n-hexane:DCM, 4:1) to afford the product as a clear resin $(2.5 \mathrm{~g}, 93 \%) .{ }^{1} \mathrm{H}-\mathrm{NMR}\left(\mathrm{CDCl}_{3}\right) \delta 6.67-7.46(\mathrm{~m}, 8 \mathrm{H}, \mathrm{Ar}-\mathrm{H}), 4.23-4.39(\mathrm{~m}, 2 \mathrm{H}$, 
$\left.\mathrm{CH}_{2}\right), 3.59-3.75\left(\mathrm{~m}, 2 \mathrm{H}, \mathrm{CH}_{2}\right), 1.46-1.78\left(\mathrm{~m}, 4 \mathrm{H}, 2 \times \mathrm{CH}_{2}\right), 1.01\left(\mathrm{~s}, 9 \mathrm{H}, 3 \times \mathrm{CH}_{3}\right), 0.23\left(\mathrm{~s}, 6 \mathrm{H}, 2 \times \mathrm{CH}_{3}\right)$. ${ }^{13} \mathrm{C}-\mathrm{NMR}\left(\mathrm{CDCl}_{3}\right) \delta$ 156.9, 154.6, 130.0, 129.7, 128.9, 128.8, 128.6, 120.1, 118.9, 113.6, 113.6, 113.5, 67.3 $\left(\mathrm{CH}_{2}\right), 32.8\left(\mathrm{CH}_{2}\right), 28.7\left(\mathrm{CH}_{2}\right), 26.6\left(\mathrm{CH}_{2}\right), 25.2\left(\mathrm{CH}_{3}\right), 17.7\left(\underline{\mathrm{C}}\left(\mathrm{CH}_{3}\right)_{3}\right),-4.8\left(\mathrm{CH}_{3}\right) . \mathrm{IR}: v_{\max }(\mathrm{KBr}) \mathrm{cm}^{-1}$ : 2955.0, 2858.7, 1651.1, 1597.8, 1508.3, 1255.3 (br.), 1169.7, 913.6. HRMS (EI): Found 487.1666 [M + H] ${ }^{+}$, $\mathrm{C}_{26} \mathrm{H}_{36} \mathrm{BrO}_{2} \mathrm{Si}$ requires 487.1668 .

(4-((4-(2-Bromoethoxy)phenyl)(cyclohexaneylidene)methyl)phenoxy)(tert-butyl)dimethylsilane (9b). Using the general method above, phenol 8b (1 eq., 2.1 g, $5.32 \mathrm{mmol}$ ), 1,2-dibromoethane (50 eq., 52.29 g, $275.8 \mathrm{mmol}, 24 \mathrm{~mL})$ and tetrabutylammonium hydrogen sulfate $(1.7 \mathrm{~g}, 5 \mathrm{mmol})$ were reacted together. The crude product was purified via flash chromatography over silica gel ( $n$-hexane:DCM, 4:1) to afford the product as a clear resin $(2.44 \mathrm{~g}, 91 \%) .{ }^{1} \mathrm{H}-\mathrm{NMR}\left(\mathrm{CDCl}_{3}\right) \delta 7.06(\mathrm{~d}, J=8.53 \mathrm{~Hz}, 2 \mathrm{H}, \mathrm{Ar}-\mathrm{H}), 6.98(\mathrm{~d}$, $J=8.28 \mathrm{~Hz}, 2 \mathrm{H}, \mathrm{Ar}-\mathrm{H}), 6.85(\mathrm{~d}, J=8.78 \mathrm{~Hz}, 2 \mathrm{H}, \mathrm{Ar}-\mathrm{H}), 6.76(\mathrm{~d}, J=8.78 \mathrm{~Hz}, 2 \mathrm{H}, \mathrm{Ar}-\mathrm{H}), 4.30(\mathrm{t}, J=6.27$ $\left.\mathrm{Hz}, 2 \mathrm{H}, \mathrm{CH}_{2}\right), 3.66\left(\mathrm{t}, \mathrm{J}=6.27 \mathrm{~Hz}, 2 \mathrm{H}, \mathrm{CH}_{2}\right), 2.23-2.31\left(\mathrm{~m}, 4 \mathrm{H}, 2 \times \mathrm{CH}_{2}\right), 1.59-1.68\left(\mathrm{~m}, 6 \mathrm{H}, 3 \times \mathrm{CH}_{2}\right)$, $1.01\left(\mathrm{~s}, 9 \mathrm{H}, 3 \times \mathrm{CH}_{3}\right), 0.23\left(\mathrm{~s}, 6 \mathrm{H}, 2 \times \mathrm{CH}_{3}\right) .{ }^{13} \mathrm{C}-\mathrm{NMR}\left(\mathrm{CDCl}_{3}\right) \delta 156.3,153.8,138.4,136.8,136.3,133.5$, 131.0, 130.8, 119.3, 114.1, $67.8\left(\mathrm{CH}_{2}\right), 32.5\left(\mathrm{CH}_{2}\right), 29.2\left(\mathrm{CH}_{2}\right), 28.7\left(\mathrm{CH}_{2}\right), 26.9\left(\mathrm{CH}_{2}\right), 25.7\left(\mathrm{CH}_{3}\right), 18.2$ $\left(\underline{\mathrm{C}}\left(\mathrm{CH}_{3}\right)_{3}\right),-4.4\left(\mathrm{CH}_{3}\right)$. IR: $v_{\max }(\mathrm{KBr}) \mathrm{cm}^{-1}: 2930.1,2857.5,1654.4,1600.6,1508.2,1471.9,1254.5,1168.0$, 913.8, 838.9, 804.6, 781.1. HRMS (EI): Found 501.1827 [M+ H] ${ }^{+}, \mathrm{C}_{27} \mathrm{H}_{38} \mathrm{BrO}_{2}$ Si requires 501.1824.

(4-((4-(2-Bromoethoxy)phenyl)(cycloheptylidene)methyl)phenoxy)(tert-butyl)dimethylsilane (9c). Following the general method above, phenol 8c (1 eq., $2.35 \mathrm{~g}, 5.70 \mathrm{mmol}), 1$,2-dibromoethane (50 eq. $56.64 \mathrm{~g}$, $298.8 \mathrm{mmol}, 26 \mathrm{~mL})$ and tetrabutylammonium hydrogen sulfate $(1.7 \mathrm{~g}, 5 \mathrm{mmol})$ were reacted together. The crude product was purified via flash chromatography over silica gel ( $n$-hexane:DCM, 4:1) to afford the product as a clear resin $(2.76 \mathrm{~g}, 94 \%) .{ }^{1} \mathrm{H}-\mathrm{NMR}\left(\mathrm{CDCl}_{3}\right) \delta 7.09(\mathrm{~d}, J=8.53 \mathrm{~Hz}, 2 \mathrm{H}, \mathrm{Ar}-\mathrm{H}), 7.00(\mathrm{~d}$, $J=8.53 \mathrm{~Hz}, 2 \mathrm{H}, \mathrm{Ar}-\mathrm{H}), 6.84(\mathrm{~d}, J=8.53 \mathrm{~Hz}, 2 \mathrm{H}, \mathrm{Ar}-\mathrm{H}), 6.75(\mathrm{~d}, J=8.53 \mathrm{~Hz}, 2 \mathrm{H}, \mathrm{Ar}-\mathrm{H}), 4.29(\mathrm{t}, J=6.27 \mathrm{~Hz}$, $\left.2 \mathrm{H}, \mathrm{CH}_{2}\right), 3.65\left(\mathrm{t}, \mathrm{J}=6.27 \mathrm{~Hz}, 2 \mathrm{H}, \mathrm{CH}_{2}\right), 2.32\left(\mathrm{~s}, 4 \mathrm{H}, 2 \times \mathrm{CH}_{2}\right), 1.59\left(\mathrm{~s}, 8 \mathrm{H}, 4 \times \mathrm{CH}_{2}\right), 0.99(\mathrm{~s}, 9 \mathrm{H}$, $\left.3 \times \mathrm{CH}_{3}\right), 0.20\left(\mathrm{~s}, 6 \mathrm{H}, 2 \times \mathrm{CH}_{3}\right) .{ }^{13} \mathrm{C}-\mathrm{NMR}\left(\mathrm{CDCl}_{3}\right) \delta 155.7,153.2,139.2,136.7,136.3,135.8,130.1,129.8$, 118.9, 113.6, $67.3\left(\mathrm{CH}_{2}\right), 32.9\left(\mathrm{CH}_{2}\right), 29.0\left(\mathrm{CH}_{2}\right), 28.8\left(\mathrm{CH}_{2}\right), 27.7\left(\mathrm{CH}_{2}\right), 25.2\left(\mathrm{CH}_{3}\right), 17.7\left(\mathrm{C}\left(\mathrm{CH}_{3}\right)_{3}\right),-4.9$ $\left(\mathrm{CH}_{3}\right)$. IR: $\nu_{\max }(\mathrm{KBr}) \mathrm{cm}^{-1}: 2929.0,2856.8,1602.8,1507.6,1471.7,1254.1,1168.0,1016.7,913.9,839.4$, 781.0. HRMS (TOF-MS): Found 514.1895 [M + H] $]^{+}, \mathrm{C}_{28} \mathrm{H}_{39} \mathrm{O}_{2} \mathrm{BrSi}$ requires 514.1903.

(4-((4-(2-Bromoethoxy)phenyl)(cyclooctylidene)methyl)phenoxy)(tert-butyl)dimethylsilane (9d). Following the general method above, phenol 8d (1 eq., 2.33 g, $5.70 \mathrm{mmol}$ ), 1,2-dibromoethane (50 eq. 56.64 g, 298.8 $\mathrm{mmol}, 26 \mathrm{~mL})$ and tetrabutylammonium hydrogen sulfate $(1.7 \mathrm{~g}, 5 \mathrm{mmol})$ were reacted together. The crude product was purified via flash chromatography over silica gel ( $n$-hexane:DCM, 4:1) to afford the product as a clear resin $(2.83 \mathrm{~g}, 94 \%)$. ${ }^{1} \mathrm{H}-\mathrm{NMR}\left(\mathrm{CDCl}_{3}\right) \delta 7.12(\mathrm{~d}, J=8.53 \mathrm{~Hz}, 2 \mathrm{H}, \mathrm{Ar}-\mathrm{H}), 7.03$ $(\mathrm{d}, J=8.03 \mathrm{~Hz}, 2 \mathrm{H}, \mathrm{Ar}-\mathrm{H}), 6.85(\mathrm{~d}, J=8.53 \mathrm{~Hz}, 2 \mathrm{H}, \mathrm{Ar}-\mathrm{H}), 6.76(\mathrm{~d}, J=8.53 \mathrm{~Hz}, 2 \mathrm{H}, \mathrm{Ar}-\mathrm{H}), 4.28(\mathrm{t}, J=$ $\left.6.27 \mathrm{~Hz}, 2 \mathrm{H}, \mathrm{CH}_{2}\right), 3.65\left(\mathrm{t}, J=6.27 \mathrm{~Hz}, 2 \mathrm{H}, \mathrm{CH}_{2}\right), 2.24-2.32\left(\mathrm{~m}, 4 \mathrm{H}, 2 \times \mathrm{CH}_{2}\right), 1.63-1.71\left(\mathrm{~m}, 2 \mathrm{H}, \mathrm{CH}_{2}\right)$, 1.48-1.63 (m, 8H, $\left.4 \times \mathrm{CH}_{2}\right), 0.99\left(\mathrm{~s}, 9 \mathrm{H}, 3 \times \mathrm{CH}_{3}\right), 0.20\left(\mathrm{~s}, 6 \mathrm{H}, 2 \times \mathrm{CH}_{3}\right) .{ }^{13} \mathrm{C}-\mathrm{NMR}\left(\mathrm{CDCl}_{3}\right) \delta 155.6$, 153.1, 139.6, 137.0, 136.5, 135.7, 129.7, 129.5, 119.1, 113.8, $67.3\left(\mathrm{CH}_{2}\right), 32.0\left(\mathrm{CH}_{2}\right), 28.8\left(\mathrm{CH}_{2}\right), 26.1\left(\mathrm{CH}_{2}\right)$, $26.0\left(\mathrm{CH}_{2}\right), 25.8\left(\mathrm{CH}_{2}\right), 25.2\left(\mathrm{CH}_{3}\right), 17.7\left(\underline{\mathrm{C}}\left(\mathrm{CH}_{3}\right)_{3}\right),-4.8\left(\mathrm{CH}_{3}\right) . \mathrm{IR}: v_{\max }(\mathrm{KBr}) \mathrm{cm}^{-1}:$ 2929.6, 2857.7, 1651.2, 1598.9, 1508.5, 1255.3 (br.), 1168.2, 912.8. HRMS (EI): Found 529.2139 [M + H] ${ }^{+}, \mathrm{C}_{29} \mathrm{H}_{42} \mathrm{BrO}_{2} \mathrm{Si}$ requires. 529.2137 .

(4-((4-(2-Bromoethoxy)phenyl)(4-methylcyclohexaneylidene) methyl)phenoxy) (tert-butyl)dimethylsilane (9e). Following the general method above, phenol $8 \mathbf{e}(1 \mathrm{eq} ., 2.3 \mathrm{~g}, 5.63 \mathrm{mmol}), 1,2$-dibromoethane (50 eq. $56.64 \mathrm{~g}, 298.8 \mathrm{mmol}, 26 \mathrm{~mL})$ and tetrabutylammonium hydrogen sulfate $(1.7 \mathrm{~g}, 5 \mathrm{mmol})$ were reacted together. The crude product was purified via flash chromatography over silica gel ( $n$-hexane:DCM, 4:1) to afford the product as a clear resin $(2.61 \mathrm{~g}, 90 \%) .{ }^{1} \mathrm{H}-\mathrm{NMR}\left(\mathrm{CDCl}_{3}\right) \delta 7.09(\mathrm{~d}, J=8.5 \mathrm{~Hz}, 2 \mathrm{H}, \mathrm{Ar}-\mathrm{H})$, $7.02(\mathrm{~d}, J=8.0 \mathrm{~Hz}, 2 \mathrm{H}, \mathrm{Ar}-\mathrm{H}), 6.87(\mathrm{~d}, J=8.5 \mathrm{~Hz}, 2 \mathrm{H}, \mathrm{Ar}-\mathrm{H}), 6.80(\mathrm{~d}, J=8.0 \mathrm{~Hz}, 2 \mathrm{H}, \mathrm{Ar}-\mathrm{H}), 4.31(\mathrm{t}, J=$ $\left.6.3 \mathrm{~Hz}, 2 \mathrm{H}, \mathrm{CH}_{2}\right), 3.67\left(\mathrm{t}, J=6.3 \mathrm{~Hz}, 2 \mathrm{H}, \mathrm{CH}_{2}\right), 2.64\left(\mathrm{t}, J=11.5 \mathrm{~Hz}, 2 \mathrm{H}, \mathrm{CH}_{2}\right), 1.96-2.03\left(\mathrm{~m}, 2 \mathrm{H}, \mathrm{CH}_{2}\right)$, $1.82\left(\mathrm{~d}, J=12.0 \mathrm{~Hz}, 2 \mathrm{H}, \mathrm{CH}_{2}\right), 1.61-1.72(\mathrm{~m}, 1 \mathrm{H}, \mathrm{CH}), 1.08-1.18\left(\mathrm{~m}, 2 \mathrm{H}, \mathrm{CH}_{2}\right), 1.04\left(\mathrm{~s}, 9 \mathrm{H}, \mathrm{CH}_{3}\right), 0.98(\mathrm{~d}$, $\left.J=6.5 \mathrm{~Hz}, 3 \mathrm{H}, \mathrm{CH}_{3}\right), 0.21\left(\mathrm{~s}, 6 \mathrm{H}, 2 \times \mathrm{CH}_{3}\right) .{ }^{13} \mathrm{C}-\mathrm{NMR}\left(\mathrm{CDCl}_{3}\right) \delta 155.9,153.4,137.6,136.3,135.9,133.2$, 
130.6, 130.4, 118.8, 118.8, 113.6, $69.3\left(\mathrm{CH}_{2}\right), 36.5\left(\mathrm{CH}_{2}\right), 32.4(\mathrm{CH}), 31.4\left(\mathrm{CH}_{2}\right), 28.8\left(\mathrm{CH}_{2}\right), 25.3\left(\mathrm{CH}_{3}\right)$,

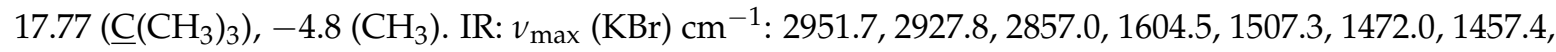
1254.1, 1168.2, 1017.15, 914.7, 839.7, 804.7, 780.5. HRMS (EI): Found 515.2006 [M + H] ${ }^{+}, \mathrm{C}_{28} \mathrm{H}_{40} \mathrm{O}_{2} \mathrm{SiBr}$ requires 515.1981 .

\subsubsection{General Method for Preparation of Amines 10a-10e}

Methylamine (2 M in THF) (20 eq.) was added to the alkyl bromide compound 9a-9e and sealed in a high pressure tube. The reaction mixture was heated to $60{ }^{\circ} \mathrm{C}$ while stirring for $48 \mathrm{~h}$. The reaction mixture was allowed sufficient time to cool, allowing the internal pressure to decrease prior to opening the pressure tube. The solvent was evaporated under reduced pressure. The oil was dissolved in DCM $(30 \mathrm{~mL})$ and was washed with a pH10 aq. solution $(30 \mathrm{~mL})$ which was then extracted with DCM $(2 \times 30 \mathrm{~mL})$. The organic layers were combined and washed with water $(50 \mathrm{~mL})$, brine $(50 \mathrm{~mL})$ and dried over $\mathrm{Na}_{2} \mathrm{SO}_{4}$. The solvent was evaporated under reduced pressure to obtain a brown oil. The crude material was purified via flash chromatography on silica gel. (DCM:EtOAc).

2-(4-((4-((tert-Butyldimethylsilyl)oxy)phenyl)(cyclopentylidene)methyl)phenoxy)-N-methylethanamine (10a). Following the general method above, 9a $(1 \mathrm{~g}, 2.05 \mathrm{mmol})$ and methylamine (20 eq., $41.02 \mathrm{mmol}$, $20 \mathrm{~mL}$ ) were reacted together. The crude material was purified via flash chromatography on silica gel (DCM:EtOAc, 2:1) to afford a brown resin $(737 \mathrm{mg}, 82 \%) .{ }^{1} \mathrm{H}-\mathrm{NMR}\left(\mathrm{CDCl}_{3}\right) \delta 7.10(\mathrm{~d}, J=8.53 \mathrm{~Hz}$, $2 \mathrm{H}, \mathrm{Ar}-\mathrm{H}), 7.03(\mathrm{~d}, J=8.53 \mathrm{~Hz}, 2 \mathrm{H}, \mathrm{Ar}-\mathrm{H}), 6.86(\mathrm{~d}, J=8.53 \mathrm{~Hz}, 2 \mathrm{H}, \mathrm{Ar}-\mathrm{H}), 6.76(\mathrm{~d}, J=8.03 \mathrm{~Hz}, 2 \mathrm{H}$, Ar-H), 4.12-4.19 (m, 2H, CH$), 3.03-3.16\left(\mathrm{~m}, 2 \mathrm{H}, \mathrm{CH}_{2}\right), 2.58\left(\mathrm{~s}, 3 \mathrm{H}, \mathrm{CH}_{3}\right), 2.34-2.44\left(\mathrm{~m}, 4 \mathrm{H}, 2 \times \mathrm{CH}_{2}\right)$, 1.63-1.73 (m, 4H, $\left.2 \times \mathrm{CH}_{2}\right), 1.00\left(\mathrm{~s}, 9 \mathrm{H}, 3 \times \mathrm{CH}_{3}\right), 0.20\left(\mathrm{~s}, 6 \mathrm{H}, 2 \times \mathrm{CH}_{3}\right) .{ }^{13} \mathrm{C}-\mathrm{NMR}\left(\mathrm{CDCl}_{3}\right) \delta 156.0$ $\left(\mathrm{C}-\mathrm{O}-\mathrm{CH}_{2}\right), 153.2,141.8,136.4,136.3,131.4,129.9,129.7,118.9,113.4,65.1\left(\mathrm{CH}_{2}\right), 49.5\left(\mathrm{CH}_{2}\right), 32.8\left(\mathrm{CH}_{3}\right)$, $26.49\left(\mathrm{CH}_{2}\right), 26.47\left(\mathrm{CH}_{2}\right), 25.2\left(\mathrm{CH}_{3}\right), 17.7\left(\mathrm{C}\left(\mathrm{CH}_{3}\right)_{3}\right),-4.8\left(\mathrm{CH}_{3}\right) . \mathrm{IR}: v_{\max }(\mathrm{KBr}) \mathrm{cm}^{-1}: 3343.1$ (br.), 2955.1, 2930.6, 2857.7, 1660.9, 1604.1, 1508.4, 1254.1 (br.), 1168.9, 915.4. HRMS (EI): Found 438.2838 $[\mathrm{M}+\mathrm{H}]^{+}, \mathrm{C}_{27} \mathrm{H}_{40} \mathrm{NO}_{2} \mathrm{Si}$ requires 438.2828 .

2-(4-((4-((tert-Butyldimethylsilyl)oxy)phenyl)(cyclohexaneylidene)methyl)phenoxy)-N-methylethanamine (10b). Following the general method above, $9 \mathrm{~b}(1 \mathrm{~g}, 2.0 \mathrm{mmol})$ and methylamine $(20$ eq., $41.02 \mathrm{mmol}$, $20 \mathrm{~mL}$ ) were reacted together. The crude material was purified via flash chromatography on silica gel (DCM:EtOAc, 2:1) to afford a brown resin $(781 \mathrm{mg}, 86 \%) .{ }^{1} \mathrm{H}-\mathrm{NMR}\left(\mathrm{CDCl}_{3}\right) \delta 7.03(\mathrm{~d}, \mathrm{~J}=8.5$ $\mathrm{Hz}, 2 \mathrm{H}, \mathrm{Ar}-\mathrm{H}), 6.96(\mathrm{~d}, J=8.5 \mathrm{~Hz}, 2 \mathrm{H}, \mathrm{Ar}-\mathrm{H}), 6.84(\mathrm{~d}, J=8.5 \mathrm{~Hz}, 2 \mathrm{H}, \mathrm{Ar}-\mathrm{H}), 6.74(\mathrm{~d}, J=8.5 \mathrm{~Hz}, 2 \mathrm{H}$, Ar-H), 4.13-4.17 (m, 2H, CH$), 3.08\left(\mathrm{~d}, J=6.5 \mathrm{~Hz}, 2 \mathrm{H}, \mathrm{CH}_{2}\right), 2.58\left(\mathrm{~s}, 3 \mathrm{H}, \mathrm{CH}_{3}\right), 2.24(\mathrm{~d}, J=5.0 \mathrm{~Hz}, 4 \mathrm{H}$, $\left.2 \times \mathrm{CH}_{2}\right), 1.56-1.63\left(\mathrm{~m}, 6 \mathrm{H}, 3 \times \mathrm{CH}_{2}\right), 0.99\left(\mathrm{~s}, 9 \mathrm{H}, \mathrm{CH}_{3}\right), 0.21\left(\mathrm{~s}, 6 \mathrm{H}, \mathrm{CH}_{3}\right) .{ }^{13} \mathrm{C}-\mathrm{NMR}\left(\mathrm{CDCl}_{3}\right) \delta 156.1$, 153.3, 137.9, 136.0, 135.8, 133.0, 130.5, 130.3, 118.8, 113.4, $65.1\left(\mathrm{CH}_{2}\right), 49.5\left(\mathrm{CH}_{2}\right), 34.7\left(\mathrm{NCH}_{3}\right), 32.1$ $\left(\mathrm{CH}_{2}\right), 32.0\left(\mathrm{CH}_{2}\right), 28.2\left(\mathrm{CH}_{2}\right), 26.4\left(\mathrm{CH}_{3}\right), 17.71\left(\mathrm{C}\left(\mathrm{CH}_{3}\right)_{3}\right),-4.83\left(\mathrm{CH}_{3}\right) . \mathrm{IR}: v_{\max }(\mathrm{KBr}) \mathrm{cm}^{-1}: 3435.1$, 2928.5, 2854.3, 1606.2, 1507.9, 1471.3, 1255.0, 1168.7, 915.1, 835.8, 778.9. HRMS (EI): Found 452.2982 [M $+\mathrm{H}^{+}, \mathrm{C}_{28} \mathrm{H}_{42} \mathrm{NO}_{2}$ Si requires 452.2985 .

2-(4-((4-((tert-Butyldimethylsilyl)oxy)phenyl)(cycloheptylidene)methyl)phenoxy)-N-methylethanamine (10c). Following the general method above, 9c $(1 \mathrm{~g}, 1.94 \mathrm{mmol})$ and methylamine ( 20 eq., $41.02 \mathrm{mmol}, 20$ $\mathrm{mL})$ were reacted together. The crude material was purified via flash chromatography over silica gel (DCM:EtOAc, 2:1) to afford a brown resin (813 mg, 90\%). ${ }^{1} \mathrm{H}-\mathrm{NMR}\left(\mathrm{CDCl}_{3}\right) \delta 7.07(\mathrm{~d}, \mathrm{~J}=8.8 \mathrm{~Hz}, 2 \mathrm{H}$, Ar-H), $7.00(\mathrm{~d}, J=8.3 \mathrm{~Hz}, 2 \mathrm{H}, \mathrm{Ar}-\mathrm{H}), 6.83(\mathrm{~d}, J=8.3 \mathrm{~Hz}, 2 \mathrm{H}, \mathrm{Ar}-\mathrm{H}), 6.74(\mathrm{~d}, J=8.3 \mathrm{~Hz}, 2 \mathrm{H}, \mathrm{Ar}-\mathrm{H}), 4.08$ $\left(\mathrm{d}, J=6.5 \mathrm{~Hz}, 2 \mathrm{H}, \mathrm{CH}_{2}\right), 3.61\left(\mathrm{~d}, J=6.5 \mathrm{~Hz}, 2 \mathrm{H}, \mathrm{CH}_{2}\right), 2.99(\mathrm{~s}, 1 \mathrm{H}, \mathrm{NH}), 2.52\left(\mathrm{~s}, 3 \mathrm{H}, \mathrm{CH}_{3}\right), 2.29-2.33$ $\left(\mathrm{m}, 4 \mathrm{H}, 2 \times \mathrm{CH}_{2}\right), 1.55-1.64\left(\mathrm{~m}, 8 \mathrm{H}, 4 \times \mathrm{CH}_{2}\right), 0.99\left(\mathrm{~s}, 9 \mathrm{H}, \mathrm{CH}_{3}\right), 0.20\left(\mathrm{~s}, 6 \mathrm{H}, \mathrm{CH}_{3}\right) .{ }^{13} \mathrm{C}-\mathrm{NMR}\left(\mathrm{CDCl}_{3}\right)$ $\delta$ 156.7, 153.6, 139.5, 136.8, 136.7, 136.4, 132.0, 130.4, 130.3, 128.5, 120.0, 119.3, 113.8, 113.6, 65.1 $\left(\mathrm{CH}_{2}\right)$, $49.5\left(\mathrm{CH}_{2}\right), 33.5\left(\mathrm{NCH}_{3}\right), 33.4\left(\mathrm{CH}_{2}\right), 29.4\left(\mathrm{CH}_{2}\right), 28.2\left(\mathrm{CH}_{2}\right), 28.1\left(\mathrm{CH}_{2}\right), 25.7\left(\mathrm{CH}_{3}\right), 18.1\left(\underline{\mathrm{C}}\left(\mathrm{CH}_{3}\right)_{3}\right)$, $-4.8\left(\mathrm{CH}_{3}\right) . \mathrm{IR}: v_{\max }(\mathrm{KBr}) \mathrm{cm}^{-1}: 3436.1,2928.1,2855.9,1604.3,1507.1,1471.7,1253.4,1171.7,1045.2$, 914.6, 839.2, 805.0, 780.6. HRMS (EI): Found 446.3152 [M+ H] ${ }^{+}, \mathrm{C}_{29} \mathrm{H}_{44} \mathrm{NO}_{2}$ Si requires 446.3141. 
2-(4-((4-((tert-Butyldimethylsilyl)oxy)phenyl)(cyclooctylidene)methyl)phenoxy)-N-methylethanamine (10d). Following the general method above, 9d $(1 \mathrm{~g}, 1.89 \mathrm{mmol})$ and methylamine (20 eq., $41.02 \mathrm{mmol}$, $20 \mathrm{~mL}$ ) were reacted together. The crude material was purified via flash chromatography over silica gel (DCM:EtOAc, 2:1) to afford a brown resin (761 mg, 84\%). ${ }^{1} \mathrm{H}-\mathrm{NMR}\left(\mathrm{CDCl}_{3}\right) \delta 7.06-7.15(\mathrm{~m}, 2 \mathrm{H}$, Ar-H), 6.98-7.06 (m, 2H, Ar-H), 6.85-6.93 (m, 2H, Ar-H), 6.71-6.79 (m, 2H, Ar-H), 4.16-4.26 (m, 2H, $\left.\mathrm{CH}_{2}\right), 3.10-3.24\left(\mathrm{~m}, 2 \mathrm{H}, \mathrm{CH}_{2}\right), 2.60\left(\mathrm{~s}, 3 \mathrm{H}, \mathrm{CH}_{3}\right), 2.20-2.32\left(\mathrm{~m}, 4 \mathrm{H}, 2 \times \mathrm{CH}_{2}\right), 1.62-1.73\left(\mathrm{~m}, 2 \mathrm{H}, \mathrm{CH}_{2}\right)$, 1.45-1.62 (m, 8H, $\left.4 \times \mathrm{CH}_{2}\right), 0.99\left(\mathrm{~s}, 9 \mathrm{H}, 3 \times \mathrm{CH}_{3}\right), 0.19\left(\mathrm{~s}, 6 \mathrm{H}, 2 \times \mathrm{CH}_{3}\right) .{ }^{13} \mathrm{C}-\mathrm{NMR}\left(\mathrm{CDCl}_{3}\right) \delta 155.4$ $\left(\mathrm{C}-\mathrm{O}-\mathrm{CH}_{2}\right), 153.1,139.6,137.1,136.5,135.6,129.6,129.4,119.1,113.8,63.3\left(\mathrm{CH}_{2}\right), 48.5\left(\mathrm{CH}_{2}\right), 33.6\left(\mathrm{CH}_{3}\right)$,

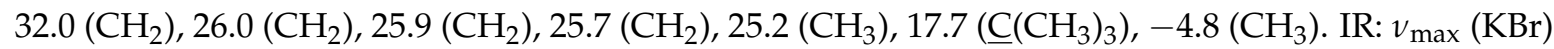
$\mathrm{cm}^{-1}$ : 3413.8 (br.), 2927.7, 2856.0, 1643.2, 1605.9, 1506.7, 1241.1 (br.), 1168.5, 835.8. HRMS (EI): Found $480.3301[\mathrm{M}+\mathrm{H}]^{+}, \mathrm{C}_{30} \mathrm{H}_{46} \mathrm{NO}_{2}$ Si requires 480.3298 .

2-(4-((4-((tert-Butyldimethylsilyl)oxy)phenyl)(4-methylcyclohexaneylidene)methyl)phenoxy)-N-methylethanamine (10e). Following the general method above, $9 \mathbf{e}(1 \mathrm{~g}, 1.94 \mathrm{mmol})$ and methylamine $(\sim 20$ eq., $41.02 \mathrm{mmol}, 20 \mathrm{~mL}$ ) were reacted together. The crude material was purified via flash chromatography on silica gel (DCM:EtOAc, 2:1) to afford a brown resin $(722 \mathrm{mg}, 80 \%) .{ }^{1} \mathrm{H}-\mathrm{NMR}\left(\mathrm{CDCl}_{3}\right) \delta 7.04(\mathrm{~d}$, $J=7.0 \mathrm{~Hz}, 2 \mathrm{H}, \mathrm{Ar}-\mathrm{H}), 6.97(\mathrm{~d}, J=8.5 \mathrm{~Hz}, 2 \mathrm{H}, \mathrm{Ar}-\mathrm{H}), 6.84(\mathrm{~d}, J=8.5 \mathrm{~Hz}, 2 \mathrm{H}, \mathrm{Ar}-\mathrm{H}), 6.75(\mathrm{~d}, J=8.5 \mathrm{~Hz}$, $2 \mathrm{H}, \mathrm{Ar}-\mathrm{H}), 4.09\left(\mathrm{t}, J=4.5 \mathrm{~Hz}, 2 \mathrm{H}, \mathrm{CH}_{2}\right), 3.01\left(\mathrm{~s}, 2 \mathrm{H}, \mathrm{CH}_{2}\right), 2.75(\mathrm{~s}, 1 \mathrm{H}, \mathrm{NH}), 2.54-2.62\left(\mathrm{~m}, 5 \mathrm{H}, \mathrm{CH}_{3}\right.$, $\left.\mathrm{CH}_{2}\right), 1.95\left(\mathrm{t}, J=12.5 \mathrm{~Hz}, 2 \mathrm{H}, \mathrm{CH}_{2}\right), 1.78\left(\mathrm{~d}, 2 \mathrm{H}, \mathrm{CH}_{2}\right), 1.60-1.64(\mathrm{~m}, 1 \mathrm{H}, \mathrm{CH}), 1.09(\mathrm{q}, J=12.0 \mathrm{~Hz}, 2 \mathrm{H}$, $\left.\mathrm{CH}_{2}\right), 1.00\left(\mathrm{~s}, 9 \mathrm{H}, \mathrm{CH}_{3}\right), 0.94\left(\mathrm{~d}, J=6.6 \mathrm{~Hz}, 3 \mathrm{H}, \mathrm{CH}_{3}\right), 0.22\left(\mathrm{~s}, 6 \mathrm{H}, \mathrm{CH}_{3}\right) .{ }^{13} \mathrm{C}-\mathrm{NMR}\left(\mathrm{CDCl}_{3}\right) \delta 156.5$, 153.3, 137.4, 135.9, 135.8, 133.2, 130.5, 130.4, 130.4, 118.8, 113.3, $66.1\left(\mathrm{CH}_{2}\right), 50.2\left(\mathrm{CH}_{2}\right), 36.4\left(\mathrm{CH}_{2}\right), 35.6$

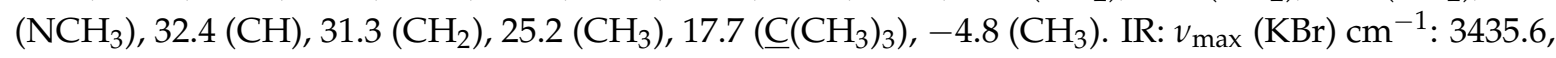
2946.9, 2927.7, 2856.3, 1605.4, 1507.9, 1457.6, 1471.9, 1253.3, 1168.5, 1045.1, 915.2, 838.1, 805.0, 780.0. HRMS (EI): Found $466.3156[\mathrm{M}+\mathrm{H}]^{+}, \mathrm{C}_{29} \mathrm{H}_{44} \mathrm{NO}_{2} \mathrm{Si}$ requires 466.3141.

\subsubsection{General Method for Preparation of Cyclofenil Derivatives 11a-11e}

The appropriate silyl ether 10a-10e was dissolved in THF $(3 \mathrm{~mL})$ while stirring under $\mathrm{N}_{2}$. An equimolar quantity of TBAF ( $1 \mathrm{M}$ in THF) was added and the mixture was allowed to stir for 30 min. The reaction was monitored via TLC. The solvent was evaporated to dryness. The residue was redissolved in DCM $(20 \mathrm{~mL})$ and washed with a $10 \% \mathrm{HCl}$ solution $(10 \mathrm{~mL})$. The organic phase was dried over $\mathrm{Na}_{2} \mathrm{SO}_{4}$ and evaporated to dryness in vacuo. The residue is purified via flash chromatography on silica gel to afford the products.

4-(Cyclopentylidene(4-(2-(methylamino)ethoxy)phenyl)methyl)phenol (11a). Following the general deprotection method, the cyclofenil derivative $10 \mathrm{a}(200 \mathrm{mg}, 0.457 \mathrm{mmol})$ and TBAF (1 M in THF) $(0.457 \mathrm{mmol}, 0.457 \mathrm{ml})$ were reacted together in THF $(3 \mathrm{~mL})$. The residue was purified via flash chromatography on silica gel (DCM:MeOH, gradient 50:1 to 40:1) to afford the product as a pale pink solid (107 mg, 73\%), m.p. $160-163{ }^{\circ} \mathrm{C} .{ }^{1} \mathrm{H}-\mathrm{NMR}\left(\mathrm{CDCl}_{3}\right) \delta 9.23-9.42(\mathrm{~m}, 1 \mathrm{H}, \mathrm{OH}), 7.03(\mathrm{~d}, J=8.53 \mathrm{~Hz}$, 2H, Ar-H), $6.92(\mathrm{~d}, J=8.53 \mathrm{~Hz}, 2 \mathrm{H}, \mathrm{Ar}-\mathrm{H}), 6.86(\mathrm{~d}, J=8.53 \mathrm{~Hz}, 2 \mathrm{H}, \mathrm{Ar}-\mathrm{H}), 6.68(\mathrm{~d}, J=8.53 \mathrm{~Hz}, 2 \mathrm{H}$, Ar-H), $4.00\left(\mathrm{t}, J=5.52 \mathrm{~Hz}, 2 \mathrm{H}, \mathrm{CH}_{2}\right), 2.84\left(\mathrm{t}, J=5.27 \mathrm{~Hz}, 2 \mathrm{H}, \mathrm{CH}_{2}\right), 2.35\left(\mathrm{~s}, 3 \mathrm{H}, \mathrm{NCH}_{3}\right), 2.26-2.34(\mathrm{~m}, 4 \mathrm{H}$, $\left.2 \times \mathrm{CH}_{2}\right), 1.54-1.69\left(\mathrm{~m}, 4 \mathrm{H}, 2 \times \mathrm{CH}_{2}\right) .{ }^{13} \mathrm{C}-\mathrm{NMR}\left(\mathrm{CDCl}_{3}\right) \delta 157.1,155.9,140.9,136.3,134.5,132.4,130.3$, 115.2, 114.3, $67.2\left(\mathrm{CH}_{2}\right), 50.6\left(\mathrm{CH}_{2}\right), 36.4\left(\mathrm{NCH}_{3}\right), 33.2\left(\mathrm{CH}_{2}\right), 26.9\left(\mathrm{CH}_{2}\right) . \mathrm{IR}: v_{\max }(\mathrm{KBr}) \mathrm{cm}^{-1}: 3438.3$ (br.), 2952.55, 2864.3, 2591.1, 1608.2, 1507.1, 1268.9, 1235.6, 1053.8, 834.8. HRMS (EI): Found 324.1950 $[\mathrm{M}+\mathrm{H}]^{+}, \mathrm{C}_{21} \mathrm{H}_{26} \mathrm{NO}_{2}$ requires 324.1964.

4-(Cyclohexaneylidene(4-(2-(methylamino)ethoxy)phenyl)methyl)phenol (11b). Following the general deprotection method above, the cyclofenil derivative $10 \mathrm{~b}(200 \mathrm{mg}, 0.442 \mathrm{mmol})$ and TBAF (1 M in THF) ( $0.442 \mathrm{mmol}, 0.442 \mathrm{ml}$ ) were reacted together in THF $(3 \mathrm{~mL})$. The residue was purified via flash chromatography on silica gel (DCM:MeOH, gradient 50:1 to 40:1) to afford the product as a white solid (116 mg, 78\%), m.p. 169-170 ${ }^{\circ} \mathrm{C} .{ }^{1} \mathrm{H}-\mathrm{NMR}\left(\mathrm{DMSO}-\mathrm{d}_{6}\right) \delta 6.95(\mathrm{~d}, J=8.53 \mathrm{~Hz}, 2 \mathrm{H}, \mathrm{Ar}-\mathrm{H}), 6.77-6.88$ $(\mathrm{m}, 4 \mathrm{H}, \mathrm{Ar}-\mathrm{H}), 6.67(\mathrm{~d}, J=8.53 \mathrm{~Hz}, 2 \mathrm{H}, \mathrm{Ar}-\mathrm{H}), 3.98\left(\mathrm{t}, J=5.52 \mathrm{~Hz}, 2 \mathrm{H}, \mathrm{CH}_{2}\right), 2.80(\mathrm{t}, J=5.65 \mathrm{~Hz}, 2 \mathrm{H}$, $\left.\mathrm{CH}_{2}\right), 2.33\left(\mathrm{~s}, 3 \mathrm{H}, \mathrm{NCH}_{3}\right), 2.09-2.23\left(\mathrm{~m}, 4 \mathrm{H}, 2 \times \mathrm{CH}_{2}\right), 1.46-1.64\left(\mathrm{~m}, 6 \mathrm{H}, 3 \times \mathrm{CH}_{2}\right)(\mathrm{OH}$ not observed). 
${ }^{13}$ C-NMR $\left(\mathrm{DMSO}_{6}\right) \delta$ 157.3, 157.0, 137.0, 135.9, 134.2, 133.2, 130.9, 130.8, 115.3, 114.3, $67.5\left(\mathrm{CH}_{2}\right), 50.8$ $\left.\left(\mathrm{CH}_{2}\right), 36.6\left(\mathrm{NCH}_{3}\right), 32.4\left(\mathrm{CH}_{2}\right), 28.6\left(\mathrm{CH}_{2}\right), 23.5\left(\mathrm{CH}_{2}\right) . \mathrm{IR}: v_{\max }(\mathrm{KBr}) \mathrm{cm}^{-1}: 3438.2(\mathrm{br})\right), 2930.0,2847.3$, 2660.1, 2591.11, 1607.8, 1508.4, 1465.7, 1302.6, 1273.0, 1168.4, 1041.8, 833.7. HRMS (EI): Found 338.2104 $[\mathrm{M}+\mathrm{H}]^{+}, \mathrm{C}_{22} \mathrm{H}_{28} \mathrm{NO}_{2}$ requires 338.2120.

4-(Cycloheptylidene(4-(2-(methylamino)ethoxy)phenyl)methyl)phenol (11c). Following the general deprotection method above, the cyclofenil derivative 10c (200 mg, $0.429 \mathrm{mmol})$ and TBAF (1 M in THF) (0.429 mmol, $0.429 \mathrm{~mL})$ were reacted together in THF $(3 \mathrm{~mL})$. The residue was purified via flash chromatography on silica gel (DCM:MeOH, gradient 50:1 to 40:1) to afford the product as a pale pink solid (122 mg, 81\%), m.p. ${ }^{169-171}{ }^{\circ} \mathrm{C} .{ }^{1} \mathrm{H}-\mathrm{NMR}$ (DMSO- $\left.d_{6}\right) \delta 7.00(\mathrm{~d}, J=8.78 \mathrm{~Hz}, 2 \mathrm{H}, \mathrm{Ar}-\mathrm{H})$, 6.80-6.95 (m, 4H, Ar-H), $6.67(\mathrm{~d}, J=8.53 \mathrm{~Hz}, 2 \mathrm{H}, \mathrm{Ar}-\mathrm{H}), 3.97\left(\mathrm{t}, J=5.65 \mathrm{~Hz}, 2 \mathrm{H}, \mathrm{CH}_{2}\right), 2.80(\mathrm{t}, J=5.52 \mathrm{~Hz}$, $\left.2 \mathrm{H}, \mathrm{CH}_{2}\right), 2.33\left(\mathrm{~s}, 3 \mathrm{H}, \mathrm{NCH}_{3}\right), 2.18-2.27\left(\mathrm{~m}, 4 \mathrm{H}, 2 \times \mathrm{CH}_{2}\right), 1.46-1.63\left(\mathrm{~m}, 8 \mathrm{H}, 4 \times \mathrm{CH}_{2}\right) .{ }^{13} \mathrm{C}-\mathrm{NMR}$ $\left(\mathrm{DMSO}-d_{6}\right) \delta 157.2,156.0,138.4,137.1,136.4,134.5,130.3,130.3,115.2,114.3,67.5\left(\mathrm{CH}_{2}\right), 50.8\left(\mathrm{CH}_{2}\right)$, $36.6\left(\mathrm{NCH}_{3}\right), 33.3\left(\mathrm{CH}_{2}\right), 29.2\left(\mathrm{CH}_{2}\right), 28.0\left(\mathrm{CH}_{2}\right), 23.5\left(\mathrm{CH}_{2}\right)$. IR: $v_{\max }(\mathrm{KBr}) \mathrm{cm}^{-1}: 3440.6(\mathrm{br}), 2929.7$, 2849.4, 2575.8, 1607.4, 1505.9, 1463.3, 1274.6, 1240.8, 1168.6, 1045.2, 828.8. HRMS (EI): Found 352.2261 $[\mathrm{M}+\mathrm{H}]^{+}, \mathrm{C}_{23} \mathrm{H}_{30} \mathrm{NO}_{2}$ requires 352.2277.

4-(Cyclooctylidene(4-(2-(methylamino)ethoxy)phenyl)methyl)phenol (11d). Following the general deprotection method above, the cyclofenil 10d (200 mg, $0.417 \mathrm{mmol}$ ) and TBAF (1 M in THF) $(0.417 \mathrm{mmol}, 0.417 \mathrm{~mL})$ were reacted together in THF $(3 \mathrm{~mL})$. The residue was purified via flash chromatography on silica gel (DCM:MeOH, gradient 50:1 to 40:1) to afford the product as a clear oil (119 mg, 78\%). ${ }^{1} \mathrm{H}-\mathrm{NMR}$ (DMSO-d $) \delta 7.02(\mathrm{~d}, J=8.53 \mathrm{~Hz}, 2 \mathrm{H}, \mathrm{Ar}-\mathrm{H}), 6.80-6.93$ (m, 4H, Ar-H), 6.68 $(\mathrm{d}, J=8.53 \mathrm{~Hz}, 2 \mathrm{H}, \mathrm{Ar}-\mathrm{H}), 3.96\left(\mathrm{t}, J=5.65 \mathrm{~Hz}, 2 \mathrm{H}, \mathrm{CH}_{2}\right), 2.80\left(\mathrm{t}, J=5.77 \mathrm{~Hz}, 2 \mathrm{H}, \mathrm{CH}_{2}\right), 2.32(\mathrm{~s}, 3 \mathrm{H}$, $\left.\mathrm{NCH}_{3}\right), 2.13-2.26\left(\mathrm{~m}, 4 \mathrm{H}, 2 \times \mathrm{CH}_{2}\right), 1.40-1.68\left(\mathrm{~m}, 10 \mathrm{H}, 5 \times \mathrm{CH}_{2}\right) .{ }^{13} \mathrm{C}-\mathrm{NMR}\left(\mathrm{DMSO}-d_{6}\right) \delta 157.1,156.8$, 138.5, 137.2, 136.8, 134.1, 130.0, 129.8, 115.5, 114.5, $67.5\left(\mathrm{CH}_{2}\right), 50.8\left(\mathrm{CH}_{2}\right), 36.6\left(\mathrm{NCH}_{3}\right), 32.4\left(\mathrm{CH}_{2}\right), 26.4$ $\left(\mathrm{CH}_{2}\right), 26.2\left(\mathrm{CH}_{2}\right), 23.5\left(\mathrm{CH}_{2}\right)$. IR: $v_{\max }(\mathrm{KBr}) \mathrm{cm}^{-1}: 3438.1$ (br. $), 2932.3,2871.9,2852.2,2640.4,2566.5$, $1607.9,1587.1,1505.9,1455.8,1274.9,1239.5,1168.1,1046.6,838.9$. HRMS (EI): Found 366.2414 [M + H] ${ }^{+}$, $\mathrm{C}_{24} \mathrm{H}_{32} \mathrm{NO}_{2}$ requires 366.2433.

4-((4-(2-(Methylamino)ethoxy)phenyl)(4-methylcyclohexaneylidene)methyl)phenol (11e). Following the general deprotection method above, the cyclofenil derivative 10e (200 $\mathrm{mg}, 0.429 \mathrm{mmol})$ and TBAF (1 M in THF) (0.429 mmol, $0.429 \mathrm{~mL})$ were reacted together in THF $(3 \mathrm{~mL})$. The residue was purified via flash chromatography on silica gel (DCM:MeOH, gradient 50:1 to 40:1) to afford the product as a pale pink solid (124 mg, 82\%), m.p: $74-76{ }^{\circ} \mathrm{C} .{ }^{1} \mathrm{H}-\mathrm{NMR}\left(\mathrm{DMSO}-d_{6}\right) \delta 6.94(\mathrm{~d}, \mathrm{~J}=8.50 \mathrm{~Hz}, 2 \mathrm{H}, \mathrm{Ar}-\mathrm{H})$, 6.78-6.88 (m, 4H, Ar-H), $6.68(\mathrm{~d}, J=8.53 \mathrm{~Hz}, 2 \mathrm{H}, \mathrm{Ar}-\mathrm{H}), 3.98\left(\mathrm{t}, J=5.52 \mathrm{~Hz}, 2 \mathrm{H}, \mathrm{CH}_{2}\right), 2.80(\mathrm{t}, J=5.40$ $\left.\mathrm{Hz}, 2 \mathrm{H}, \mathrm{CH}_{2}\right), 2.48\left(\mathrm{t}, J=16.10 \mathrm{~Hz}, 2 \mathrm{H}, \mathrm{CH}_{2}\right), 2.33\left(\mathrm{~s}, 3 \mathrm{H}, \mathrm{NCH}_{3}\right), 1.90\left(\mathrm{dt}, J=3.14,12.86 \mathrm{~Hz}, 2 \mathrm{H}, \mathrm{CH}_{2}\right)$, $1.72\left(\mathrm{~d}, J=11.80 \mathrm{~Hz}, 2 \mathrm{H}, \mathrm{CH}_{2}\right), 1.51-1.63\left(\mathrm{~m}, 3 \mathrm{H}, \mathrm{CH}_{2}, \mathrm{CH}\right), 0.90\left(\mathrm{~d}, J=6.27 \mathrm{~Hz}, 3 \mathrm{H}, \mathrm{CH}_{3}\right) .{ }^{13} \mathrm{C}-\mathrm{NMR}$ $\left(\mathrm{DMSO}_{6}\right) \delta 157.3,156.6,136.7,135.9,134.3,133.6,130.9,130.8,115.2,114.3,67.5\left(\mathrm{CH}_{2}\right), 50.8\left(\mathrm{CH}_{2}\right)$, $36.6\left(\mathrm{NCH}_{3}\right), 32.7(\mathrm{CH}), 31.7\left(\mathrm{CH}_{2}\right), 23.5\left(\mathrm{CH}_{2}\right), 22.4\left(\mathrm{CH}_{3}\right)$. IR: $v_{\max }(\mathrm{KBr}) \mathrm{cm}^{-1}: 3439.7$ (br.), 2945.8 , 2913.1, 2887.4, 2866.9, 1607.06, 1505.9, 1456.2, 1270.3, 1234.5, 1168.2, 1043.6, 830.4. HRMS (EI): Found $352.2264[\mathrm{M}+\mathrm{H}]^{+}, \mathrm{C}_{23} \mathrm{H}_{30} \mathrm{NO}_{2}$ requires 352.2277 .

\subsubsection{General Method for the Synthesis of OTBDMS Cyclofenil-Acrylic Acid Conjugates 12a-12e}

A mixture of the required acrylic acid 11 (1.2 eq), EDC (1.4 eq.) and HOBt (1.4 eq.) was suspended in anhydrous dichloromethane $(3 \mathrm{~mL})$ and stirred for 10 min under a nitrogen atmosphere. The appropriate cyclofenil derivative 10a-10e (1 eq.) was dissolved in anhydrous dichloromethane (3 $\mathrm{mL}$ ) and slowly added to the mixture via syringe. The reaction was allowed stir for $16 \mathrm{~h}$. The reaction was monitored via TLC. The reaction mixture was diluted to $15 \mathrm{~mL}$ with anhydrous dichloromethane. To this mixture, water $(20 \mathrm{~mL})$ was added. The aqueous phase was extracted with DCM $(20 \mathrm{~mL} \times 3)$, brine $(50 \mathrm{~mL})$, dried over $\mathrm{Na}_{2} \mathrm{SO}_{4}$ and evaporated to dryness in vacuo to yield the crude product. The material was purified via flash chromatography on silica gel using DCM:EtOAc as eluent. 
(E)-N-(2-(4-((4-((tert-Butyldimethylsilyl)oxy)phenyl)(cyclopentylidene)methyl)phenoxy)ethyl)-3-(3hydroxy-4-methoxyphenyl)-N-methyl-2-(3,4,5-trimethoxy phenyl) acrylamide (12a). The acrylic acid 11 (1.2 eq., $196 \mathrm{mg}, 0.54 \mathrm{mmol}$ ), EDC (1.4 eq., $120 \mathrm{mg}, 0.63 \mathrm{mmol}$ ), and HOBt (1.4 eq., $85 \mathrm{mg}, 0.63$ $\mathrm{mmol}$ ) were reacted with protected cyclofenil derivative $10 \mathrm{a}(1 \mathrm{eq} ., 200 \mathrm{mg}, 0.45 \mathrm{mmol})$ following the general method above. The product was obtained as a brown resin. The material was purified via flash chromatography on silica gel (DCM:EtOAc, gradient 15:1 to 10:1) to afford the product as a yellow solid $(284 \mathrm{mg}, 81 \%)$, m.p. $87-89^{\circ} \mathrm{C}$, which was used immediately in the following reaction without further purification. ${ }^{1} \mathrm{H}-\mathrm{NMR}\left(\mathrm{CDCl}_{3}\right) \delta 6.97-7.16(\mathrm{~m}, 4 \mathrm{H}, \mathrm{Ar}-\mathrm{H}, \mathrm{C}=\mathrm{CH}), 6.52-6.88(\mathrm{~m}, 10 \mathrm{H}$, Ar-H), $4.25\left(\mathrm{~m}, 1 \mathrm{H}, 0.5 \times \mathrm{OCH}_{2}\right), 3.60-3.92\left(\mathrm{~m}, 15 \mathrm{H}, 0.5 \times \mathrm{OCH}_{2}, \mathrm{NCH}_{2}, 4 \times \mathrm{OCH}_{3}\right), 3.08-3.23(\mathrm{~m}, 3 \mathrm{H}$, $\left.\mathrm{NCH}_{3}\right), 2.40\left(\mathrm{~s}, 4 \mathrm{H}, 2 \times \mathrm{CH}_{2}\right), 1.69\left(\mathrm{~s}, 4 \mathrm{H}, 2 \times \mathrm{CH}_{2}\right), 1.00\left(\mathrm{~s}, 9 \mathrm{H}, 3 \times \mathrm{CH}_{3}\right), 0.22\left(\mathrm{~s}, 6 \mathrm{H}, 2 \times \mathrm{CH}_{3}\right)$. ${ }^{13} \mathrm{C}-\mathrm{NMR}\left(\mathrm{CDCl}_{3}\right) \delta 169.0,153.2,152.8,145.8,144.6,141.8,129.9,129.7,118.9,115.0,113.2,109.7,105.5$, $66.0\left(\mathrm{CH}_{2}\right), 60.5\left(\mathrm{OCH}_{3}\right), 55.4\left(\mathrm{OCH}_{3}\right), 38.6\left(\mathrm{CH}_{2}\right), 32.8\left(\mathrm{CH}_{2}\right), 26.5\left(\mathrm{CH}_{2}\right), 25.2\left(\mathrm{CH}_{3}\right), 17.7\left(\mathrm{C}_{\left(\mathrm{CH}_{3}\right)}\right)$, $-4.8\left(\mathrm{CH}_{3}\right)$. IR: $v_{\max }(\mathrm{KBr}) \mathrm{cm}^{-1}: 3350.9$ (br.), 2954.2, 2936.7, 2859.3, 1603.9, 1581.5, 1505.9, 1463.8, 1242.5 (br.), 1127.1, 912.2. HRMS (EI): Found 780.3922 [M + H] $]^{+}, \mathrm{C}_{46} \mathrm{H}_{58} \mathrm{NO}_{8} \mathrm{Si}$ requires 780.3932.

(E)-N-(2-(4-((4-((tert-Butyldimethylsilyl)oxy)phenyl)(cyclohexaneylidene)methyl)phenoxy)ethyl)-3-(3-hydroxy4-methoxyphenyl)-N-methyl-2-(3,4,5-trimethoxyphenyl)acrylamide (12b). The acrylic acid $\mathbf{1 1}$ (1.2 eq., $189 \mathrm{mg}, 0.526 \mathrm{mmol})$ ), EDC (1.4 eq., $118 \mathrm{mg}, 0.616 \mathrm{mmol})$ and HOBt (1.4 eq., $83 \mathrm{mg}, 0.616 \mathrm{mmol}$ ) were reacted with protected cyclofenil derivative $10 \mathrm{~b}$ (1 eq., $200 \mathrm{mg}, 0.44 \mathrm{mmol})$ following the general method above. The product was obtained as a brown resin. The material was purified via flash chromatography on silica gel (DCM:EtOAc, gradient 15:1 to 10:1) to afford the product as a yellow solid $(272 \mathrm{mg}, 78 \%)$, m.p. $88-90^{\circ} \mathrm{C}$. which was used immediately in the following reaction without further purification. ${ }^{1} \mathrm{H}-\mathrm{NMR}\left(\mathrm{CDCl}_{3}\right) \delta 6.90-7.09(\mathrm{~m}, 4 \mathrm{H}, \mathrm{Ar}-\mathrm{H}, \mathrm{C}=\mathrm{CH}), 6.52-6.85(\mathrm{~m}, 10 \mathrm{H}, \mathrm{Ar}-\mathrm{H})$, 4.17-4.29 (m, 1H, $\left.0.5 \times \mathrm{OCH}_{2}\right), 3.57-3.91\left(\mathrm{~m}, 15 \mathrm{H}, 0.5 \times \mathrm{OCH}_{2}, \mathrm{NCH}_{2}, 4 \times \mathrm{OCH}_{3}\right), 3.07-3.26(\mathrm{~m}, 3 \mathrm{H}$, $\left.\mathrm{NCH}_{3}\right), 2.18-2.30\left(\mathrm{~m}, 4 \mathrm{H}, 2 \times \mathrm{CH}_{2}\right), 1.52-1.69\left(\mathrm{~m}, 6 \mathrm{H}, 3 \times \mathrm{CH}_{2}\right), 1.00\left(\mathrm{~s}, 9 \mathrm{H}, 3 \times \mathrm{CH}_{3}\right), 0.21(\mathrm{~s}, 6 \mathrm{H}, 2$ $\left.\times \mathrm{CH}_{3}\right) .{ }^{13} \mathrm{C}-\mathrm{NMR}\left(\mathrm{CDCl}_{3}\right) \delta 170.0,153.3,152.8,145.9,144.6,130.5,130.3,121.5,118.8,115.0,113.1$, 109.7, 105.5, $66.1\left(\mathrm{CH}_{2}\right), 60.5\left(\mathrm{OCH}_{3}\right), 55.4\left(\mathrm{OCH}_{3}\right), 32.0\left(\mathrm{CH}_{2}\right), 28.2\left(\mathrm{CH}_{2}\right), 26.4\left(\mathrm{CH}_{2}\right), 25.2\left(\mathrm{CH}_{3}\right), 17.7$ $\left(\underline{\mathrm{C}}\left(\mathrm{CH}_{3}\right)_{3}\right),-4.8\left(\mathrm{CH}_{3}\right)$. HRMS (EI): Found $794.4079[\mathrm{M}+\mathrm{H}]^{+}, \mathrm{C}_{47} \mathrm{H}_{60} \mathrm{NO}_{8} \mathrm{Si}$ requires 794.4088.

(E)-N-(2-(4-((4-((tert-Butyldimethylsilyl)oxy)phenyl)(cycloheptylidene)methyl)phenoxy)ethyl)-3-(3-hydroxy-4methoxyphenyl)-N-methyl-2-(3,4,5-trimethoxyphenyl)acrylamide (12c). The acrylic acid 11 (1.2 eq., 185 mg, $0.516 \mathrm{mmol}), \mathrm{EDC}(1.4 \mathrm{eq} ., 118 \mathrm{mg}, 0.616 \mathrm{mmol})$ and HOBt $(1.4 \mathrm{eq} ., 83 \mathrm{mg}, 0.616 \mathrm{mmol})$ were reacted with protected cyclofenil derivative 10c (1 eq., $200 \mathrm{mg}, 0.43 \mathrm{mmol}$ ) following the general method above. The product was obtained as a brown resin. The material was purified via flash chromatography on silica gel (DCM:EtOAc, gradient 15:1 to 10:1) to afford the product as a yellow solid (284 $\mathrm{mg}, 81 \%)$, m.p. $84-86^{\circ} \mathrm{C}$ which was used immediately in the following reaction without further purification. ${ }^{1} \mathrm{H}-\mathrm{NMR}\left(\mathrm{CDCl}_{3}\right) \delta 6.93-7.12(\mathrm{~m}, 4 \mathrm{H}, \mathrm{Ar}-\mathrm{H}, \mathrm{C}=\mathrm{CH}), 6.50-6.86(\mathrm{~m}, 10 \mathrm{H}, \mathrm{Ar}-\mathrm{H}), 5.64$ (br. s., $\left.1 \mathrm{H}, \mathrm{OH}\right)$, 4.17-4.27 (m, 1H, $\left.0.5 \times \mathrm{OCH}_{2}\right), 3.55-3.95\left(\mathrm{~m}, 15 \mathrm{H}, 0.5 \times \mathrm{OCH}_{2}, \mathrm{NCH}_{2}, 4 \times \mathrm{OCH}_{3}\right), 3.06-3.24(\mathrm{~m}, 3 \mathrm{H}$, $\left.\mathrm{NCH}_{3}\right), 2.24-2.37\left(\mathrm{~m}, 4 \mathrm{H}, 2 \times \mathrm{CH}_{2}\right), 1.49-1.64\left(\mathrm{~m}, 8 \mathrm{H}, 4 \times \mathrm{CH}_{2}\right), 0.99\left(\mathrm{~s}, 9 \mathrm{H}, 3 \times \mathrm{CH}_{3}\right), 0.20(\mathrm{~s}, 6 \mathrm{H}, 2$ $\left.\times \mathrm{CH}_{3}\right) .{ }^{13} \mathrm{C}-\mathrm{NMR}\left(\mathrm{CDCl}_{3}\right) \delta 172.1,156.6,153.7,153.3,146.4,145.1,139.7,137.9,136.8,136.3,135.9$, $130.5,130.3,129.9,128.6,122.0,119.4,115.5,113.7,110.2,105.8,66.5\left(\mathrm{CH}_{2}\right), 60.9\left(\mathrm{OCH}_{3}\right), 56.0\left(\mathrm{OCH}_{3}\right)$, $55.9\left(\mathrm{OCH}_{3}\right), 47.7\left(\mathrm{CH}_{2}\right), 39.0\left(\mathrm{NCH}_{3}\right), 33.5\left(\mathrm{CH}_{2}\right), 33.4\left(\mathrm{CH}_{2}\right), 29.4\left(\mathrm{CH}_{2}\right), 28.2\left(\mathrm{CH}_{2}\right), 28.1\left(\mathrm{CH}_{2}\right), 25.7$ $\left(\mathrm{CH}_{3}\right), 18.2\left(\underline{\mathrm{C}}\left(\mathrm{CH}_{3}\right)_{3}\right),-4.4\left(\mathrm{CH}_{3}\right)$. IR: $v_{\max }(\mathrm{KBr}) \mathrm{cm}^{-1}: 3436.1$ (br.). HRMS (EI): Found 830.4050 $[\mathrm{M}+\mathrm{H}]^{+}, \mathrm{C}_{48} \mathrm{H}_{61} \mathrm{NNaO}_{8} \mathrm{Si}$ requires 830.4064.

(E)-N-(2-(4-((4-((tert-Butyldimethylsilyl)oxy)phenyl)(cyclooctylidene)methyl)phenoxy)ethyl)-3-(3-hydroxy-4methoxyphenyl)-N-methyl-2-(3,4,5-trimethoxyphenyl)acrylamide (12d). The acrylic acid 11 (1.2 eq., $180 \mathrm{mg}$, $0.5 \mathrm{mmol})$ ), EDC (1.4 eq., $118 \mathrm{mg}, 0.616 \mathrm{mmol}$ ) and HOBt $(1.4$ eq., $83 \mathrm{mg}, 0.616 \mathrm{mmol}$ ) were reacted with protected cyclofenil derivative $10 \mathrm{~d}$ ( 1 eq., $200 \mathrm{mg}, 0.416 \mathrm{mmol}$ ) following the general method above. The product was afforded as a brown resin. The material was purified via flash chromatography on silica gel (DCM:EtOAc, gradient 15:1 to 10:1) to afford the product as a yellow solid (243 $\mathrm{mg}, 71 \%)$, m.p. $89-91{ }^{\circ} \mathrm{C}$ which was used immediately in the following reaction without further purification. 
${ }^{1} \mathrm{H}-\mathrm{NMR}\left(\mathrm{CDCl}_{3}\right)$ 8 6.95-7.15 (m, 4H, Ar-H, C=CH), 6.51-6.87 (m, 10H, Ar-H), 4.17-4.27 (m, 1H, $0.5 \times$ $\left.\mathrm{OCH}_{2}\right), 3.56-3.94\left(\mathrm{~m}, 15 \mathrm{H}, 0.5 \times \mathrm{OCH}_{2}, \mathrm{NCH}_{2}, 4 \times \mathrm{OCH}_{3}\right), 3.05-3.23\left(\mathrm{~m}, 3 \mathrm{H}, \mathrm{NCH}_{3}\right), 2.20-2.34(\mathrm{~m}$, $\left.4 \mathrm{H}, 2 \times \mathrm{CH}_{2}\right), 1.62-1.73\left(\mathrm{~m}, 2 \mathrm{H}, \mathrm{CH}_{2}\right), 1.48-1.61\left(\mathrm{~m}, 8 \mathrm{H}, 4 \times \mathrm{CH}_{2}\right), 0.99\left(\mathrm{~s}, 9 \mathrm{H}, 3 \times \mathrm{CH}_{3}\right), 0.20(\mathrm{~s}, 6 \mathrm{H}, 2$ $\left.\times \mathrm{CH}_{3}\right) .{ }^{13} \mathrm{C}-\mathrm{NMR}\left(\mathrm{CDCl}_{3}\right) \delta 171.1,156.4,153.1,152.8,145.9,144.7,139.5,136.6,135.7,135.4,129.7$, 129.4, 128.1, 121.5, 119.1, 115.0, 113.4, 109.7, 105.5, $66.1\left(\mathrm{CH}_{2}\right), 60.5\left(\mathrm{OCH}_{3}\right), 60.0\left(\mathrm{OCH}_{3}\right), 55.6\left(\mathrm{OCH}_{3}\right)$, $55.4\left(\mathrm{OCH}_{3}\right), 47.2\left(\mathrm{CH}_{2}\right), 38.6\left(\mathrm{NCH}_{3}\right), 32.1\left(\mathrm{CH}_{2}\right), 32.0\left(\mathrm{CH}_{2}\right), 26.1\left(\mathrm{CH}_{2}\right), 26.0\left(\mathrm{CH}_{2}\right), 25.9\left(\mathrm{CH}_{2}\right)$, $25.8\left(\mathrm{CH}_{2}\right), 25.2\left(\mathrm{CH}_{3}\right), 17.7\left(\underline{\mathrm{C}}\left(\mathrm{CH}_{3}\right)_{3}\right),-4.9\left(\mathrm{CH}_{3}\right) . \mathrm{IR}: v_{\max }(\mathrm{KBr}) \mathrm{cm}^{-1}: 3425.7$ (br.), 2929.0, 2856.1, 1633.8, 1603.9, 1581.6, 1505.9, 1463.7, 1240.2, 1126.2, 838.3. HRMS (EI): Found $844.4200[\mathrm{M}+\mathrm{H}]^{+}$, $\mathrm{C}_{49} \mathrm{H}_{63} \mathrm{NNaO}_{8} \mathrm{Si}$ requires 844.4221.

(E)-N-(2-(4-((4-((tert-butyldimethylsilyl)oxy)phenyl)(4-methylcyclo hexaneylidene)methyl)phenoxy) ethyl)-3-(3-hydroxy-4-methoxyphenyl)-N-methyl-2-(3,4,5-trimethoxyphenyl)acrylamide (12e). The acrylic acid 11 (1.2 eq., $189 \mathrm{mg}, 0.526 \mathrm{mmol})$, EDC (1.4 eq., $118 \mathrm{mg}, 0.616 \mathrm{mmol}$ ) and HOBt (1.4 eq., $83 \mathrm{mg}, 0.616 \mathrm{mmol}$ ) were reacted with protected cyclofenil derivative 10e (1 eq., $200 \mathrm{mg}, 0.429$ $\mathrm{mmol}$ ) following the general method above The product was afforded as a brown resin. The material was purified via flash chromatography on silica gel (DCM:EtOAc, gradient 15:1 to 10:1) to afford the product as a yellow solid $(294 \mathrm{mg}, 85 \%)$, m.p. $89-93{ }^{\circ} \mathrm{C}$ which was used immediately in the following reaction without further purification. ${ }^{1} \mathrm{H}-\mathrm{NMR}\left(\mathrm{CDCl}_{3}\right) \delta 6.88-7.09(\mathrm{~m}, 4 \mathrm{H}, \mathrm{Ar}-\mathrm{H}, \mathrm{C}=\mathrm{CH}), 6.53-6.86$ (m, 10H, Ar-H), 5.50-5.89 (br. s., $1 \mathrm{H}, \mathrm{OH}), 4.23\left(\mathrm{~m}, 1 \mathrm{H}, 0.5 \times \mathrm{OCH}_{2}\right), 3.57-3.92\left(\mathrm{~m}, 15 \mathrm{H}, 0.5 \times \mathrm{OCH}_{2}\right.$, $\left.\mathrm{NCH}_{2}, 4 \times \mathrm{OCH}_{3}\right), 3.07-3.24\left(\mathrm{~m}, 3 \mathrm{H}, \mathrm{NCH}_{3}\right), 2.50-2.64\left(\mathrm{~m}, 2 \mathrm{H}, \mathrm{CH}_{2}\right), 1.87-2.00\left(\mathrm{~m}, 2 \mathrm{H}, \mathrm{CH}_{2}\right), 1.72-1.78$ (m, 2H, $\left.\mathrm{CH}_{2}\right), 1.05-1.14\left(\mathrm{~m}, 2 \mathrm{H}, \mathrm{CH}_{2}\right), 1.00\left(\mathrm{~s}, 9 \mathrm{H}, 3 \times \mathrm{CH}_{3}\right), 0.91-0.97\left(\mathrm{~m}, 3 \mathrm{H}, \mathrm{CH}_{3}\right), 0.21(\mathrm{~s}, 6 \mathrm{H}, 2$ $\left.\times \mathrm{CH}_{3}\right) .{ }^{13} \mathrm{C}-\mathrm{NMR}\left(\mathrm{CDCl}_{3}\right) \delta 171.7,156.3,153.3,152.8,145.9,144.7,137.5,135.9,135.4,133.1,130.5$, 130.3, 128.1, 121.5, 118.8, 115.0, 113.1, 109.7, 105.5, $66.1\left(\mathrm{CH}_{2}\right), 60.5\left(\mathrm{OCH}_{3}\right), 60.0\left(\mathrm{OCH}_{3}\right), 55.6\left(\mathrm{OCH}_{3}\right)$, 55.4 $\left(\mathrm{OCH}_{3}\right), 47.2\left(\mathrm{CH}_{2}\right), 38.5\left(\mathrm{NCH}_{3}\right) 36.4\left(\mathrm{CH}_{2}\right), 32.3(\mathrm{CH}), 31.3\left(\mathrm{CH}_{2}\right), 25.2\left(\mathrm{CH}_{3}\right), 21.6\left(\mathrm{CH}_{3}\right), 17.7$ $\left(\underline{\mathrm{C}}\left(\mathrm{CH}_{3}\right)_{3}\right),-4.8\left(\mathrm{CH}_{3}\right)$. IR: $v_{\max }(\mathrm{KBr}) \mathrm{cm}^{-1}: 3436.6$ (br.), 2929.1, 2852.2, 1628.9, 1604.4, 1581.8, 1505.9, 1463.4, 1239.6, 1126.1, 839.5. HRMS (EI): Found 808.4211 [M + H] $]^{+}, \mathrm{C}_{48} \mathrm{H}_{62} \mathrm{NO}_{8} \mathrm{Si}$ requires 808.4239.

\subsubsection{General Method for Deprotection of tert-Butyldimethylsilyl Ethers 12a-12e}

The appropriate silyl ether 12a-12e was dissolved in a minimum amount of THF ( $3 \mathrm{~mL}$ ) while stirring under $\mathrm{N}_{2}$. An equimolar quantity of TBAF ( $1 \mathrm{M}$ in THF) was added and the mixture was allowed to stir for $30 \mathrm{~min}$. The reaction was monitored via TLC. The solvent was evaporated to dryness. The residue was redissolved in DCM $(20 \mathrm{~mL})$ and washed with a $10 \% \mathrm{HCl}$ solution $(10 \mathrm{~mL})$. The organic phase was dried over $\mathrm{Na}_{2} \mathrm{SO}_{4}$ and evaporated to dryness in vacuo. The residue is purified via flash chromatography on silica gel to afford the product.

(E)-N-(2-(4-(Cyclopentylidene(4-hydroxyphenyl)methyl)phenoxy)ethyl)-3-(3-hydroxy-4-methoxyphenyl)-Nmethyl-2-(3,4,5-trimethoxyphenyl)acrylamide (13a). The protected cyclofenil-acrylic acid derivative 12a $(150 \mathrm{mg}, 0.192 \mathrm{mmol})$ and TBAF ( $1 \mathrm{M}$ in THF) $(0.192 \mathrm{mmol}, 0.192 \mathrm{~mL})$ were reacted together in THF ( $3 \mathrm{~mL}$ ) following the general method above. The residue was purified via flash chromatography on silica gel (DCM:EtOAc, gradient 5:1 to 2:1) to afford the product as a yellow solid (116 mg, 91\%), m.p. 159-162 ${ }^{\circ} \mathrm{C} .{ }^{1} \mathrm{H}-\mathrm{NMR}\left(\mathrm{CDCl}_{3}\right)$ 8 6.96-7.14 (m, 4H, Ar-H, C=CH), 6.47-6.91 (m, 10H, Ar-H), 4.19-4.28 $\left(\mathrm{m}, 1 \mathrm{H}, 0.5 \times \mathrm{OCH}_{2}\right), 3.56-3.95\left(\mathrm{~m}, 15 \mathrm{H}, 0.5 \times \mathrm{OCH}_{2}, \mathrm{NCH}_{2}, 4 \times \mathrm{OCH}_{3}\right), 3.10-3.26\left(\mathrm{~m}, 3 \mathrm{H}, \mathrm{NCH}_{3}\right)$, 2.31-2.45 (m, 4H, $\left.2 \times \mathrm{CH}_{2}\right), 1.62-1.74\left(\mathrm{~m}, 4 \mathrm{H}, 2 \times \mathrm{CH}_{2}\right) .{ }^{13} \mathrm{C}-\mathrm{NMR}\left(\mathrm{CDCl}_{3}\right) \delta 171.5,156.1,153.7,152.9$, $145.9,144.6,141.7,136.3,135.5,135.2,131.3,129.9,128.0,121.6,115.0,114.4,113.2,109.7,105.5,66.0$ $\left(\mathrm{CH}_{2}\right), 60.5\left(\mathrm{OCH}_{3}\right), 55.6\left(\mathrm{OCH}_{3}\right), 55.4\left(\mathrm{OCH}_{3}\right), 47.4\left(\mathrm{CH}_{2}\right), 32.8\left(\mathrm{CH}_{3}\right), 29.3\left(\mathrm{CH}_{2}\right), 26.5\left(\mathrm{CH}_{2}\right) . \mathrm{IR}: v_{\max }$ $(\mathrm{KBr}) \mathrm{cm}^{-1}$ : 3433.5 (br.), 2933.4, 2862.0, 1603.9, 1508.1, 1408.8, 1238.4, 1125.3, 835.2. HRMS (EI): Found $688.2868[\mathrm{M}+\mathrm{Na}]^{+}, \mathrm{C}_{40} \mathrm{H}_{43} \mathrm{NNaO}_{8}$ requires 688.2886.

(E)-N-(2-(4-(Cyclohexaneylidene(4-hydroxyphenyl)methyl)phenoxy)ethyl)-3-(3-hydroxy-4-methoxyphenyl)-Nmethyl-2-(3,4,5-trimethoxyphenyl)acrylamide (13b). The protected cyclofenil-acrylic acid derivative $\mathbf{1 2 b}$ $(150 \mathrm{mg}, 0.189 \mathrm{mmol})$ and TBAF $(1 \mathrm{M}$ in THF) $(0.189 \mathrm{mmol}, 0.189 \mathrm{ml})$ were reacted together in THF ( $3 \mathrm{~mL}$ ) following the general method above. The residue was purified via flash chromatography on 
silica gel (DCM:EtOAc, gradient 5:1 to 2:1) to afford the product as a yellow solid (119 mg, 93\%), m.p. 166-170 ${ }^{\circ} \mathrm{C} .{ }^{1} \mathrm{H}-\mathrm{NMR}\left(\mathrm{CDCl}_{3}\right)$ 8 6.87-7.07 (m, 4H, Ar-H), 6.50-6.84 (m, 10H, Ar-H), 4.17-4.31 (m, 1H, $\left.0.5 \times \mathrm{CH}_{2}\right), 3.54-3.95\left(\mathrm{~m}, 15 \mathrm{H}, 0.5 \times \mathrm{CH}_{2}, \mathrm{CH}_{2}, 3 \times \mathrm{OCH}_{3}\right), 3.08-3.24\left(\mathrm{~m}, 3 \mathrm{H}, \mathrm{NCH}_{3}\right), 2.17-2.30(\mathrm{~m}$, $\left.4 \mathrm{H}, 2 \times \mathrm{CH}_{2}\right), 1.50-1.67\left(\mathrm{~m}, 6 \mathrm{H}, 3 \times \mathrm{CH}_{2}\right) .{ }^{13} \mathrm{C}-\mathrm{NMR}\left(\mathrm{CDCl}_{3}\right) \delta 172.1,154.0,152.9,146.0,144.7,137.8$, $137.3,135.2,134.9,132.9,130.5,130.5,129.6,128.0,121.6,115.0,114.3,113.2,109.7,105.5,66.0\left(\mathrm{CH}_{2}\right), 60.5$ $\left(\mathrm{OCH}_{3}\right), 60.0\left(\mathrm{OCH}_{3}\right), 55.6\left(\mathrm{OCH}_{3}\right), 55.4\left(\mathrm{OCH}_{3}\right), 47.3\left(\mathrm{CH}_{2}\right), 38.7\left(\mathrm{CH}_{3}\right), 32.0\left(\mathrm{CH}_{2}\right), 28.2\left(\mathrm{CH}_{2}\right), 26.4$ $\left(\mathrm{CH}_{2}\right)$. IR: $v_{\max }(\mathrm{KBr}) \mathrm{cm}^{-1}$ : 3425.4 (br.), 2926.5, 2847.3, 1605.2, 1582.5, 1510.9, 1449.1, 1273.8, 1237.5, 1125.7, 1026.9, 835.4. HRMS (EI): Found 702.3026 [M + Na $]^{+}, \mathrm{C}_{41} \mathrm{H}_{45} \mathrm{NNaO}_{8}$ requires 702.3043.

(E)-N-(2-(4-(Cycloheptylidene(4-hydroxyphenyl)methyl)phenoxy)ethyl)-3-(3-hydroxy-4-methoxyphenyl)-Nmethyl-2-(3,4,5-trimethoxyphenyl)acrylamide (13c). The protected cyclofenil-acrylic acid derivative 12c $(150 \mathrm{mg}, 0.185 \mathrm{mmol})$ and TBAF $(1 \mathrm{M}$ in THF) $(0.185 \mathrm{mmol}, 0.185 \mathrm{ml})$ were reacted together in THF ( $3 \mathrm{~mL}$ ) following the general method above. The residue was purified via flash chromatography on silica gel (DCM:EtOAc, gradient 5:1 to 2:1) to afford the product as a yellow solid (113 mg, 98\%), m.p. 162-163 ${ }^{\circ} \mathrm{C} .{ }^{1} \mathrm{H}-\mathrm{NMR}\left(\mathrm{CDCl}_{3}\right)$ 8 6.92-7.12 (m, 4H, Ar-H, C=CH), 6.49-6.84 (m, 10H, Ar-H), 4.16-4.26 $\left(\mathrm{m}, 1 \mathrm{H}, 0.5 \times \mathrm{OCH}_{2}\right), 3.53-3.93\left(\mathrm{~m}, 15 \mathrm{H}, 0.5 \times \mathrm{OCH}_{2}, \mathrm{NCH}_{2}, 4 \times \mathrm{OCH}_{3}\right)$, 3.0. ${ }^{13} \mathrm{C}-\mathrm{NMR}\left(\mathrm{CDCl}_{3}\right) \delta$ 172.2, 156.6, 154.3, 153.3, 146.4, 145.1, 139.6, 137.8, 136.9, 136.2, 135.8, 135.6, 130.5, 130.4, 130.1, 128.5, 122.0, 115.5, 114.9, 113.7, 110.2, 106.1, $66.4\left(\mathrm{CH}_{2}\right), 60.9\left(\mathrm{OCH}_{3}\right), 60.5\left(\mathrm{CH}_{2}\right), 56.0\left(\mathrm{OCH}_{3}\right), 55.9\left(\mathrm{OCH}_{3}\right)$, $53.5\left(\mathrm{CH}_{2}\right), 50.1\left(\mathrm{CH}_{2}\right), 47.8\left(\mathrm{CH}_{2}\right), 39.1\left(\mathrm{NCH}_{3}\right), 33.4\left(\mathrm{CH}_{2}\right), 29.4\left(\mathrm{CH}_{2}\right), 28.1\left(\mathrm{CH}_{2}\right)$. IR: $v_{\max }(\mathrm{KBr})$ $\mathrm{cm}^{-1}$ : 3437.4 (br.), 2923.4, 2842.2, 160.3, 1582.3, 1506.0, 1410.0, 1273.7, 1238.2, 1125.3, 831.2. HRMS (EI): Found $716.3185[\mathrm{M}+\mathrm{Na}]^{+}, \mathrm{C}_{42} \mathrm{H}_{47} \mathrm{NNaO}_{8}$ requires 716.3199 .

(E)-N-(2-(4-(Cyclooctylidene(4-hydroxyphenyl)methyl)phenoxy)ethyl)-3-(3-hydroxy-4-methoxyphenyl)-Nmethyl-2-(3,4,5-trimethoxyphenyl)acrylamide (13d). The protected cyclofenil-acrylic acid derivative 12e $(150 \mathrm{mg}, 0.182 \mathrm{mmol})$ and TBAF $(1 \mathrm{M}$ in THF) $(0.182 \mathrm{mmol}, 0.182 \mathrm{ml})$ were reacted together in THF $(3 \mathrm{~mL}$ ) following the general method above. The residue was purified via flash chromatography on silica gel (DCM:EtOAc, gradient 5:1 to 2:1) to afford the product as a yellow solid (102 mg, 79\%), m.p. 158-159 ${ }^{\circ} \mathrm{C} .{ }^{1} \mathrm{H}-\mathrm{NMR}\left(\mathrm{CDCl}_{3}\right) \delta 6.92-7.13(\mathrm{~m}, 4 \mathrm{H}, \mathrm{Ar}-\mathrm{H}, \mathrm{C}=\mathrm{CH}), 6.50-6.86(\mathrm{~m}, 10 \mathrm{H}, \mathrm{Ar}-\mathrm{H}), 4.16-4.25$ $\left(\mathrm{m}, 1 \mathrm{H}, 0.5 \times \mathrm{OCH}_{2}\right), 3.51-3.95\left(\mathrm{~m}, 15 \mathrm{H}, 0.5 \times \mathrm{OCH}_{2}, \mathrm{NCH}_{2}, 4 \times \mathrm{OCH}_{3}\right), 3.05-3.24\left(\mathrm{~m}, 3 \mathrm{H}, \mathrm{NCH}_{3}\right)$, 2.17-2.36 (m, 4H, $\left.2 \times \mathrm{CH}_{2}\right), 1.62-1.74\left(\mathrm{~m}, 2 \mathrm{H}, \mathrm{CH}_{2}\right), 1.45-1.61\left(\mathrm{~m}, 8 \mathrm{H}, 4 \times \mathrm{CH}_{2}\right) .{ }^{13} \mathrm{C}-\mathrm{NMR}\left(\mathrm{CDCl}_{3}\right) \delta$ 172.4, 156.6, 153.8, 152.9, 146.0, 144.7, 139.4, 139.4, 137.3, 135.6, 135.2, 133.9, 129.6, 129.6, 121.6, 115.0, 114.6, 113.4, 109.8, 105.5, $65.9\left(\mathrm{CH}_{2}\right), 60.5\left(\mathrm{OCH}_{3}\right), 60.1\left(\mathrm{CH}_{2}\right), 55.5\left(\mathrm{OCH}_{3}\right), 55.4\left(\mathrm{OCH}_{3}\right), 39.1\left(\mathrm{NCH}_{3}\right)$, $32.0\left(\mathrm{CH}_{2}\right), 26.1\left(\mathrm{CH}_{2}\right), 25.9\left(\mathrm{CH}_{2}\right), 25.8\left(\mathrm{CH}_{2}\right)$. IR: $v_{\max }(\mathrm{KBr}) \mathrm{cm}^{-1}: 3437.6$ (br.), 2927.9, 2847.3, 1604.1, 1582.3, 1505.9, 1274.6, 1238.3, 1125.6, 831.6. HRMS (EI): Found $730.3336\left[\mathrm{M}+\mathrm{Na}^{+}, \mathrm{C}_{43} \mathrm{H}_{49} \mathrm{NNaO}_{8}\right.$ requires 730.3356 .

(E)-3-(3-Hydroxy-4-methoxyphenyl)-N-(2-(4-((4-hydroxyphenyl)(4-methylcyclohexaneylidene)methyl)-phenoxy) ethyl)-N-methyl-2-(3,4,5-trimethoxy phenyl) acrylamide (13e). The protected cyclofenil-acrylic acid derivative $12 \mathrm{e}(150 \mathrm{mg}, 0.186 \mathrm{mmol})$ and TBAF $(1 \mathrm{M}$ in THF) $(0.186 \mathrm{mmol}, 0.186 \mathrm{ml})$ were reacted together in THF $(3 \mathrm{~mL})$ following the general method above. The residue was purified via flash chromatography on silica gel (DCM:EtOAc; gradient 5:1 to 2:1) to afford the product as a yellow solid (110 mg, 86\%), m.p. $158-161{ }^{\circ} \mathrm{C} .{ }^{1} \mathrm{H}-\mathrm{NMR}\left(\mathrm{CDCl}_{3}\right) \delta 6.87-7.06(\mathrm{~m}, 4 \mathrm{H}, \mathrm{Ar}-\mathrm{H}), 6.51-6.84(\mathrm{~m}, 10 \mathrm{H}$, Ar-H), 4.17-4.27 (m, 1H, $\left.0.5 \times \mathrm{CH}_{2}\right), 3.54-3.94\left(\mathrm{~m}, 15 \mathrm{H}, 0.5 \times \mathrm{OCH}_{2}, \mathrm{NCH}_{2}, 4 \times \mathrm{OCH}_{3}\right), 3.08-3.25$ $\left(\mathrm{m}, 3 \mathrm{H}, \mathrm{NCH}_{3}\right), 2.49-2.64\left(\mathrm{~m}, 2 \mathrm{H}, \mathrm{CH}_{2}\right), 1.93\left(\mathrm{t}, J=11.54 \mathrm{~Hz}, 2 \mathrm{H}, \mathrm{CH}_{2}\right), 1.76(\mathrm{~d}, J=10.54 \mathrm{~Hz}, 2 \mathrm{H}$, $\left.\mathrm{CH}_{2}\right), 1.55-1.68(\mathrm{~m}, 1 \mathrm{H}, \mathrm{CH}), 1.01-1.15\left(\mathrm{~m}, 2 \mathrm{H}, \mathrm{CH}_{2}\right), 0.87-0.98\left(\mathrm{~m}, 3 \mathrm{H}, \mathrm{CH}_{3}\right) .{ }^{13} \mathrm{C}-\mathrm{NMR}\left(\mathrm{CDCl}_{3}\right) \delta$ 172.2, 154.1, 152.8, 146.0, 144.7, 137.4, 134.8, 133.1, 130.5, 130.5, 128.0, 121.6, 115.0, 114.3, 113.2, 109.8, 105.5, $65.9\left(\mathrm{CH}_{2}\right), 60.5\left(\mathrm{OCH}_{3}\right), 60.1\left(\mathrm{OCH}_{3}\right), 55.5\left(\mathrm{OCH}_{3}\right), 55.4\left(\mathrm{OCH}_{3}\right), 47.4\left(\mathrm{CH}_{3}\right), 38.7\left(\mathrm{NCH}_{3}\right), 36.4$ $\left(\mathrm{CH}_{2}\right), 32.3(\mathrm{CH}), 31.3\left(\mathrm{CH}_{2}\right), 21.6\left(\mathrm{CH}_{3}\right)$. IR: $v_{\max }(\mathrm{KBr}) \mathrm{cm}^{-1}: 3421.5$ (br.), 2912.0, 2840.1, 1605.5, 1582.3, 1508.4, 1454.1, 1274.2, 1237.9, 1125.8, 830.8. HRMS (EI): Found $694.3359[\mathrm{M}+\mathrm{H}]^{+}, \mathrm{C}_{42} \mathrm{H}_{48} \mathrm{NO}_{8}$ requires 694.3380 . 
N-\{2-[4-(1,2-Diphenylbut-1-enyl)phenoxy]ethyl\}-N-methylsuccinamic acid (14a). (i) The amine $2 \mathbf{b}(0.10 \mathrm{~g}$, $0.28 \mathrm{mmol})$ and succinic anhydride $(0.03 \mathrm{~g}, 0.28 \mathrm{mmol})$ were dissolved in dry DCM $(5 \mathrm{~mL})$. The reaction was allowed stir at room temperature for $16 \mathrm{~h}$. (The reaction was monitored via TLC, DCM:MeOH, 4:1). The reaction mixture was diluted with DCM $(10 \mathrm{~mL})$, washed with $1 \mathrm{M} \mathrm{NaOH}$ solution $(10 \mathrm{~mL})$. The aqueous phase was extracted with DCM $(10 \mathrm{~mL} \times 3)$. The combined organic layers were acidified with dilute $\mathrm{HCl}$ dropwise, washed with water $(10 \mathrm{~mL})$ and brine $(10 \mathrm{~mL})$, dried over sodium sulfate and then evaporated to dryness in vacuo to afford the product 14a $(0.13 \mathrm{~g}, 97 \%)$ as a light brown oil. (ii) Succinic acid (0.05 g, $0.42 \mathrm{mmol})$, dicyclohexylcarbodiimide (DCC) (0.09 g, $0.42 \mathrm{mmol})$ and 1-hydroxy benzotriazole hydrate (HOBt) were dissolved in dry DCM ( $5 \mathrm{~mL})$ under a $\mathrm{N}_{2}$ environment. The mixture was allowed to stir for 20 minutes before adding a solution of $\mathbf{1 b}(0.15 \mathrm{~g}, 0.42 \mathrm{mmol})$ in dry DCM (3 mL). The reaction was allowed stir at room temperature for $24 \mathrm{~h}$ until no starting material was visible by TLC (DCM:MeOH = 4:1). The reaction mixture was filtered to remove the dicyclohexylurea and then evaporated in vacuo and the residue was purified via flash chromatography on silica gel (DCM:MeOH = 20:1) to afford an isomeric mixture $(E: Z=1: 1)$ of the product as a light brown oil $(0.17 \mathrm{~g}$, 90\% yield). ${ }^{1} \mathrm{H}-\mathrm{NMR}\left(\mathrm{CDCl}_{3}\right): \delta 0.95-1.00\left(\mathrm{~m}, 6 \mathrm{H}, \mathrm{CH}_{3}\right), 2.47-2.57\left(\mathrm{~m}, 4 \mathrm{H}, \mathrm{CH}_{2}\right), 2.61-2.86(\mathrm{~m}, 8 \mathrm{H}$, succinic $\left.\mathrm{CH}_{2}\right), 2.99-3.21\left(\mathrm{~m}, 6 \mathrm{H}, \mathrm{NCH}_{3}\right), 3.65-4.18\left(\mathrm{~m}, 8 \mathrm{H}, \mathrm{CH}_{2} \mathrm{~N}, \mathrm{CH}_{2} \mathrm{O}\right), 6.54-7.40(\mathrm{~m}, 28 \mathrm{H}, \mathrm{ArH})$, $8.72(\mathrm{~s}, 2 \mathrm{H}, \mathrm{COOH}) .{ }^{13} \mathrm{C}-\mathrm{NMR}\left(\mathrm{CDCl}_{3}\right): \delta 13.65,28.08,28.46,28.50,29.06,29.58,29.88,34.19,34.26$, $37.48,37.55,48.29,48.33,49.17,49.26,64.71,65.04,66.25,66.59,113.22,113.97,114.00,125.71,125.75$, $126.09,126.14,126.59,127.34,127.81,127.91,127.95,128.15,129.47,129.71,130.68,130.77,131.98,132.06$, $135.86,136.32,136.37,136.83,138.14,138.29,141.50,141.69,142.02,142.14,142.26,142.32,142.42,143.21$, $143.29,143.75,155.98,156.36,156.86,157.21,172.32,172.69,176.78,176.85$. IR: $v_{\max }(\mathrm{KBr}) \mathrm{cm}^{-1}: 3054.8$, 2969.2, 1732.2, 1606.5, 1507.4, 1463.1, 1442.2, 1407.6, 1283.3, 1241.3, 1174.0, 1138.9, 1074.1, 1054.4, 1030.3, 909.8, 732.1. HRMS (EI): Found 480.2162 [M + Na] ${ }^{+}, \mathrm{C}_{29} \mathrm{H}_{31} \mathrm{NO}_{4} \mathrm{Na}$ requires 480.2151.

N-[2-(4-\{1-[4-(tert-Butyldimethylsilanyloxy)phenyl]-2-phenylbut-1-enyl\}phenoxy)ethyl]-N-methyl-succinamic acid $\mathbf{( 1 4 b )}$. The amine $\mathbf{2 b}(0.20 \mathrm{~g}, 0.41 \mathrm{mmol}, E / Z=1: 1)$ and succinic anhydride $(0.04 \mathrm{~g}, 0.41 \mathrm{mmol})$ were dissolved in dry DCM $(5 \mathrm{~mL})$. The reaction was allowed stir at room temperature for $16 \mathrm{~h}$ and monitored via TLC (DCM:MeOH = 4:1). The reaction mixture was diluted with DCM $(10 \mathrm{~mL})$ and washed with $1 \mathrm{M} \mathrm{NaOH}$ solution $(10 \mathrm{~mL})$. The aqueous phase was extracted with DCM $(10 \mathrm{~mL} \times 3)$. The combined organic layers were acidified with dilute $\mathrm{HCl}$ dropwise, washed with water $(10 \mathrm{~mL})$ and brine $(10 \mathrm{~mL})$, dried over sodium sulfate and then evaporated to dryness in vacuo to afford an isomeric mixture $(E: Z=1: 1)$ of the product $(222 \mathrm{mg}, 92 \%)$ as a light brown oil. ${ }^{1} \mathrm{H}-\mathrm{NMR}\left(\mathrm{CDCl}_{3}\right)$ : $\delta$ 0.12-0.25 (m, 12H, Si $\left.\left(\mathrm{CH}_{3}\right)_{2}\right), 0.94-1.02\left(\mathrm{~m}, 24 \mathrm{H}, \mathrm{SiC}\left(\mathrm{CH}_{3}\right)_{3}\right), 2.48-2.52\left(\mathrm{~m}, 4 \mathrm{H}, \mathrm{CH}_{2}\right), 2.65-2.87$ $\left(\mathrm{m}, 8 \mathrm{H}, 4 \times \mathrm{CH}_{2}\right), 3.00-3.22\left(\mathrm{~m}, 6 \mathrm{H}, \mathrm{NCH}_{3}\right), 3.70-4.17\left(\mathrm{~m}, 8 \mathrm{H}, \mathrm{CH}_{2} \mathrm{~N}, \mathrm{CH}_{2} \mathrm{O}\right), 6.49-7.20(\mathrm{~m}, 26 \mathrm{H}, \mathrm{ArH})$. ${ }^{13} \mathrm{C}-\mathrm{NMR}\left(\mathrm{CDCl}_{3}\right): \delta-4.92,-4.80,13.18,13.22,17.75,25.22,25.24,28.46,28.60,37.04,37.10,47.91$, $65.78,66.12,112.65,113.42,118.53,119.10,125.46,127.31,127.39,127.43,129.26,130.09,130.22,130.30$, 131.38, 131.57, 131.65, 135.73, 136.20, 136.27, 137.37, 137.44, 140.65, 142.08, 153.06, 156.68, 172.69, 176.78. IR: $v_{\max }(\mathrm{KBr}) \mathrm{cm}^{-1}: 3435.7,2927.5,1696.5,1624.0,1603.6,1509.3,1417.2,1248.5,1202.1,1167.1,928.4$, 837.0. HRMS (EI): Found 610.2972 [M+ Na ${ }^{+}, \mathrm{C}_{35} \mathrm{H}_{45} \mathrm{NO}_{5} \mathrm{SiNa}$ requires 610.2965.

N-(2-\{4-[1,2-Bis-(4-hydroxyphenyl)but-1-enyl]phenoxy\}ethyl)-N-methylsuccinamic acid (14c). The protected acid $14 \mathrm{~b}(0.09 \mathrm{~g}, 0.15 \mathrm{mmol})$ was treated with TBAF following the general deprotection method above and afforded an isomeric mixture $(E: Z=1: 1)$ of product $13 \mathrm{c}$ as a brown oil $(0.06 \mathrm{~g}, 82 \%)$. ${ }^{1} \mathrm{H}-\mathrm{NMR}$ $\left(\mathrm{CDCl}_{3}\right)$ : $\delta$ 0.92-0.96 (m, 6H, $\left.\mathrm{CH}_{3}\right), 2.47-2.70\left(\mathrm{~m}, 12 \mathrm{H}, \mathrm{CH}_{2}\right.$, succinic $\left.\mathrm{CH}_{2}\right), 2.95-3.16\left(\mathrm{~m}, 6 \mathrm{H}, \mathrm{NCH}_{3}\right)$, 3.61-3.76 (m, 4H, CH $2 \mathrm{~N}), 3.96-3.97\left(\mathrm{~m}, 2 \mathrm{H}, \mathrm{CH}_{2} \mathrm{O}\right), 4.11-4.12\left(\mathrm{~m}, 2 \mathrm{H}, \mathrm{CH}_{2} \mathrm{O}\right), 6.49-7.17(\mathrm{~m}, 26 \mathrm{H}$, $\mathrm{ArH}) .{ }^{13} \mathrm{C}-\mathrm{NMR}\left(\mathrm{CDCl}_{3}\right): \delta 13.48,13.52,28.76,28.90,37.34,37.40,48.21,66.08,66.42,112.95,113.72$, $118.83,119.40,125.86,127.61,127.69,127.73,129.56,130.39,130.52,130.60,131.68,131.87,131.95,136.03$, $136.50,136.57,137.67,137.74,140.95,142.38,153.36,156.98,172.99,177.08$. IR: $v_{\max }(\mathrm{KBr}) \mathrm{cm}^{-1}: 3435.7$, 2930.6, 1713.4, 1604.6, 1505.6, 1408.2, 1254.2, 1171.6, 912.1, 838.3. HRMS (EI): Found $496.2115[\mathrm{M}+\mathrm{H}]^{+}$, $\mathrm{C}_{29} \mathrm{H}_{31} \mathrm{NO}_{5} \mathrm{Na}$ requires 496.2100 . 
N-\{2-[4-((Z)-1,2-Diphenylbut-1-enyl)phenoxy]ethyl\}-N-methylsuccinamic acid 2-methoxy-5-[(Z)-2-(3,4,5trimethoxyphenyl)vinyl]phenyl ester (16a). $N$-\{2-[4-(1,2-Diphenylbut-1-enyl)phenoxy]ethyl\}- $N$-methylsuccinamic acid 13a $(0.11 \mathrm{~g}, 0.24 \mathrm{mmol})$, dicyclohexylcarbodiimide $(0.05 \mathrm{~g}, 0.24 \mathrm{mmol})$ and 1-hydroxybenzotriazole hydrate $(0.03 \mathrm{~g}, 0.24 \mathrm{mmol})$ were dissolved in dry DCM $(5 \mathrm{~mL})$ under nitrogen atmosphere. The mixture was stired for 20 min before adding a solution of combretastatin A-4 15 $(0.15 \mathrm{~g}, 0.42 \mathrm{mmol})$ in dry DCM $(3 \mathrm{~mL})$. The reaction was stirred at room temperature for $24 \mathrm{~h}$ until no starting material was visible by TLC (DCM:MeOH $=4: 1)$. The reaction mixture was filtered to remove the dicyclohexylurea byproduct. The mixture was evaporated to dryness in vacuo and the material was purified via flash chromatography on silica gel (DCM:MeOH $=20: 1)$ to afford the product as an isomeric mixture $(E: Z=1: 1)$ as a light yellow oil $(150 \mathrm{mg}, 83 \%$ yield $) .{ }^{1} \mathrm{H}-\mathrm{NMR}\left(\mathrm{CDCl}_{3}\right): \delta 0.92-0.98(\mathrm{~m}$, $\left.6 \mathrm{H}, \mathrm{CH}_{3}\right), 2.45-2.55\left(\mathrm{~m}, 4 \mathrm{H}, \mathrm{CH}_{2}\right), 2.67-3.24\left(\mathrm{~m}, 14 \mathrm{H}\right.$, succinic $\left.\mathrm{CH}_{2}, \mathrm{NCH}_{3}\right), 3.69-4.26\left(\mathrm{~m}, 32 \mathrm{H}, \mathrm{OCH}_{3}\right.$, $\left.\mathrm{OCH}_{3}, \mathrm{NCH}_{3}\right), 6.47-7.39(\mathrm{~m}, 42 \mathrm{H}, \mathrm{ArH}) .{ }^{13} \mathrm{C}-\mathrm{NMR}\left(\mathrm{CDCl}_{3}\right): \delta 13.17,24.53,25.18,25.68,28.58,33.51$, 36.95, 47.67, 48.63, 55.47, 55.47, 55.64, 60.46, 60.53, 102.86, 105.39, 106.08, 111.50, 111.92, 112.76, 113.50, $122.89,124.82,125.21,125.61,125.99,126.52,126.85,127.09,127.33,127.43,127.67,128.19,129.00,129.24$, 129.65, 130.20, 130.35, 131.49, 132.01, 135.82, 139.55, 149.78, 152.48, 152.92, 170.91, 174.44. IR: $v_{\max }(\mathrm{KBr})$ $\mathrm{cm}^{-1}: 3434.8,3326.8,2929.3,2850.8,1764.3,1626.5,1578.1,1508.5,1243.5,1127.1,701.3$. HRMS (EI): Found $778.3353\left[\mathrm{M}+\mathrm{Na}^{+}, \mathrm{C}_{47} \mathrm{H}_{49} \mathrm{NO}_{8} \mathrm{Na}\right.$ requires 778.3356 .

$N-(2-\{4-[(Z)-1-(4-H y d r o x y p h e n y l)-2-p h e n y l b u t-1-e n y l] p h e n o x y\} e t h y l)-N-m e t h y l \quad$ succinamic acid 2-methoxy-5- [(Z)-2-(3,4,5-trimethoxyphenyl)vinyl]phenyl ester $\mathbf{1 6 b} . \quad N$-[2-(4-\{1-[4-(tertButyldimethylsilanyloxy)-phenyl]-2-phenylbut-1-enyl\}phenoxy)ethyl]- $N$-methylsuccinamic acid (14b, $0.10 \mathrm{~g}, 0.17 \mathrm{mmol})$, dicyclohexylcarbodiimide $(0.04 \mathrm{~g}, 0.17 \mathrm{mmol})$ and 1-hydroxybenzotriazole hydrate $(0.02 \mathrm{~g}, 0.17 \mathrm{mmol})$ were dissolved in dry DCM $(5 \mathrm{~mL})$ under a nitrogen atmosphere. The mixture was allowed to stir for 20 minutes before adding a solution of combretastatin A-4 $14(0.05 \mathrm{~g}, 0.17 \mathrm{mmol})$ in dry DCM $(3 \mathrm{~mL})$. The reaction was allowed stir at room temperature for $24 \mathrm{~h}$ until no starting material was visible by TLC (DCM:MeOH $=4: 1$ ). The reaction mixture was filtered to remove the dicyclohexylurea byproduct. The mixture was evaporated to dryness in vacuo. The residue was dissolved in $3 \mathrm{~mL}$ anhydrous THF and stirred under a nitrogen atmosphere. A quantity of $0.1 \mathrm{M}$ TBAF $(0.20 \mathrm{~mL}, 0.02 \mathrm{mmol})$ was added to the mixture and allowed stir for $24 \mathrm{~h}$. The mixture was evaporated to dryness under reduced pressure. The residue was dissolved in DCM and washed with $10 \% \mathrm{HCl}$ solution. The resulting organic phase was dried over sodium sulfate and evaporated to dryness under vacuum. The residue was purified via flash chromatography on silica gel (DCM:MeOH, 20:1) to yield an isomeric mixture $(E: Z=1: 1)$ of the product $16 \mathbf{b}(115 \mathrm{mg}, 88 \%) .{ }^{1} \mathrm{H}-\mathrm{NMR}\left(\mathrm{CDCl}_{3}\right): \delta 0.92-0.96$ $\left(\mathrm{m}, 6 \mathrm{H}, \mathrm{CH}_{3}\right), 2.46-2.54\left(\mathrm{~m}, 4 \mathrm{H}, \mathrm{CH}_{2}\right), 2.61-3.20\left(\mathrm{~m}, 14 \mathrm{H}, 4 \times \mathrm{CH}_{2}, \mathrm{NCH}_{3}\right), 3.67-3.88\left(\mathrm{~m}, 28 \mathrm{H}, \mathrm{OCH}_{3}\right.$, $\left.\mathrm{NCH}_{3}\right), 3.97\left(\mathrm{t}, 0.48 \times 4 \mathrm{H}, J=5.0 \mathrm{~Hz}, \mathrm{CH}_{2} \mathrm{O}\right), 4.13\left(\mathrm{t}, 0.52 \times 4 \mathrm{H}, J=5.0 \mathrm{~Hz}, \mathrm{CH}_{2} \mathrm{O}\right), 6.42-6.56(\mathrm{~m}, 10 \mathrm{H}$, $\mathrm{ArH}), 6.42-6.56(\mathrm{~m}, 14 \mathrm{H}, \mathrm{ArH}), 7.07-7.18(\mathrm{~m}, 16 \mathrm{H}, \mathrm{ArH}) .{ }^{13} \mathrm{C}-\mathrm{NMR}\left(\mathrm{CDCl}_{3}\right): \delta 13.22,24.46,25.13,27.95$, 28.58, 28.82, 33.43, 36.91, 36.98, 47.73, 48.68, 51.40, 53.02, 55.47, 55.50, 60.49, 64.37, 65.91, 66.24, 105.41, $105.55,109.91,111.51,112.65,113.42,113.91,114.63,120.65,122.87,125.41,127.38,128.53,129.09,129.28$, 129.63, 130.11, 130.19, 130.28, 131.57, 132.31, 134.68, 135.79, 136.26, 136.57, 137.48, 142.21, 142.29, 144.81, 145.38, 149.74, 152.38, 152.45, 153.87, 154.84, 155.87, 156.72, 171.20, 173.27. IR: $v_{\max }(\mathrm{KBr}) \mathrm{cm}^{-1}: 3429.3$, 2930.5, 2347.8, 1735.7, 1627.6, 1580.6, 1508.3, 1264.8, 1240.1, 1171.1, 1127.2, 834.6, 732.1. HRMS (EI): Found $794.3306[\mathrm{M}+\mathrm{Na}]^{+}, \mathrm{C}_{47} \mathrm{H}_{49} \mathrm{NO}_{9} \mathrm{Na}$ requires 794.3305 .

$N-\{2-[4-((Z)-1,2-D i p h e n y l b u t-1-e n y l) p h e n o x y] e t h y l\}-N-m e t h y l s u c c i n a m i c \quad$ acid 2-methoxy-5- $[(E)-2-$ methoxycarbonyl-2-(3,4,5-trimethoxyphenyl)vinyl]phenyl ester (16c). N-\{2-[4-(1,2-Diphenylbut-1-enyl)phenoxy]ethyl\}- $N$-methylsuccinamic acid $(\mathbf{1 4 a}, 0.06 \mathrm{~g}, 0.14 \mathrm{mmol})$, dicyclohexylcarbodiimide $(0.03 \mathrm{~g}$, $0.14 \mathrm{mmol})$ and 1-hydroxybenzo triazole hydrate $(0.017 \mathrm{~g}, 0.136 \mathrm{mmol})$ were dissolved in dry DCM $(5 \mathrm{~mL})$ under a $\mathrm{N}_{2}$ environment. The mixture was allowed to stir for $20 \mathrm{~min}$ before adding a solution of the combretastatin analogue $1 \mathrm{~s}(0.05 \mathrm{~g}, 0.14 \mathrm{mmol})$ in dry DCM $(3 \mathrm{~mL})$. The reaction was allowed stir at room temperature for $24 \mathrm{~h}$ until no starting material was visible by TLC (DCM:MeOH $=4: 1)$. The reaction mixture was filtered to remove the dicyclohexylurea byproduct. The mixture was evaporated 
to dryness in vacuo and the material was purified via flash chromatography on silica gel (DCM:MeOH $=20: 1)$ to afford an isomeric mixture $(E: Z=1: 1)$ of the product as a light yellow oil (108 $\mathrm{mg}, 97 \%$ yield). ${ }^{1} \mathrm{H}-\mathrm{NMR}\left(\mathrm{CDCl}_{3}\right): \delta 0.92-0.98\left(\mathrm{~m}, 6 \mathrm{H}, \mathrm{CH}_{3}\right), 2.44-2.55\left(\mathrm{~m}, 4 \mathrm{H}, \mathrm{CH}_{2}\right), 2.65-3.22\left(\mathrm{~m}, 14 \mathrm{H}, 4 \times \mathrm{CH}_{2}\right.$, $\left.\mathrm{NCH}_{3}\right), 3.74-4.18\left(\mathrm{~m}, 38 \mathrm{H}, \mathrm{OCH}_{3}, \mathrm{NCH}_{3}, \mathrm{CH}_{2} \mathrm{O}\right), 6.45-7.38(\mathrm{~m}, 40 \mathrm{H}, \mathrm{ArH}) .{ }^{13} \mathrm{C}-\mathrm{NMR}\left(\mathrm{CDCl}_{3}\right): \delta$ 13.16, 24.51, 25.17, 28.58, 33.50, 48.70, 51.95, 52.01, 55.45, 55.51, 55.65, 55.74, 60.48, 65.99, 66.31, 103.35, 106.00, 106.18, 109.71, 111.40, 111.71, 112.74, 113.48, 116.24, 122.66, 125.08, 125.21, 125.59, 126.30, 126.84, 127.14, 127.32, 128.99, 129.99, 130.12, 130.20, 130.26, 130.34, 130.73, 131.48, 133.08, 138.94, 141.87, 152.83, 153.19, 167.81, 170.63, 170.70. IR: $v_{\max }(\mathrm{KBr}) \mathrm{cm}^{-1}: 3430.0,3326.7,2929.2,2850.5,1765.4,1710.4,1626.6$, 1579.5, 1509.0, 1274.4, 1243.7, 1126.3, 1025.2, 771.1, 701.4. HRMS (EI): Found $836.3388[\mathrm{M}+\mathrm{Na}]^{+}$, $\mathrm{C}_{49} \mathrm{H}_{51} \mathrm{NO}_{10} \mathrm{Na}$ requires 836.3411.

\subsubsection{Stability Study for Compounds $16 a, 16 b$ and $16 c$}

Analytical high-performance liquid chromatography (HPLC) stability studies were performed using a Symmetry ${ }^{\circledR}$ column $\left(\mathrm{C}_{18}, 5 \mu \mathrm{m}, 4.6 \times 150 \mathrm{~mm}\right)$, a Waters 2487 Dual Wavelength Absorbance detector, a Waters 1525 binary HPLC pump and a Waters 717 plus Autosampler. Samples were detected at wavelength of $254 \mathrm{~nm}$. All samples were analysed using acetonitrile (80\%):water (20\%) as the mobile phase over $10 \mathrm{~min}$ and a flow rate of $1 \mathrm{~mL} / \mathrm{min}$. Stock solutions are prepared by dissolving $5 \mathrm{mg}$ of each of the compounds 16a, 16b and 16c in $10 \mathrm{~mL}$ of mobile phase. Phosphate buffers at the desired $\mathrm{pH}$ values $(4,7.4$, and 9) were prepared in accordance with the British Pharmacopoeia monograph 2017. Thirty $\mu \mathrm{L}$ of stock solution was diluted with $1 \mathrm{~mL}$ of appropriate buffer, shaken and injected immediately. Samples were withdrawn and analysed at time intervals of $t=0 \mathrm{~min}, 5 \mathrm{~min}, 30 \mathrm{~min}$, $60 \mathrm{~min}, 90 \mathrm{~min}, 120 \mathrm{~min}, 24 \mathrm{~h}$ and $48 \mathrm{~h}$.

\subsection{Biochemical Evaluation}

\subsubsection{Cell Culture of MCF-7 Cell Line}

The human breast carcinoma cell line, MCF-7, was purchased from the European Collection of Animal Cell Cultures (ECACC, Public Health England, Porton Down, UK). The cells were maintained in MCF-7 complete medium; consisting of Eagle's Minimum Essential Medium (MEM) supplemented with 10\% $(v / v)$ Foetal Bovine Serum (FBS), $2 \mathrm{mM}$ L-glutamine, $100 \mu \mathrm{g} / \mathrm{mL}$ penicillin/streptomycin and $1 \%(v / v)$ non-essential amino acids. Cell cultures were maintained at $37^{\circ} \mathrm{C}$ under a humidified atmosphere of $5 \% \mathrm{CO}_{2} / 95 \% \mathrm{O}_{2}$. The MTT assay was performed according to the reported protocol. The tetrazolium salt, 3-(4,5-dimethylthiazol-2-yl)-2,5-diphenyltetrazolium bromide (MTT) is taken up only by metabolically active cells and cleaved to form a formazan dye by mitochondrial dehydrogenases [30]. Assays were repeated in three experiments performed in triplicate (unless otherwise stated) and reported results represent the mean value \pm standard error mean. Graphs of percentage cell viability versus concentration of the subject compound were processed using PRISM [78].

\subsubsection{Alamar Blue Assay for Measurement of Antiproliferative Effects}

The biochemical assay was performed in triplicate on at least three independent occasions for the determinationof the mean values reported. MCF-7 cells were seeded in triplicate in 96-well plates at a density of $2.5 \times 10^{4}$ cells $/ \mathrm{mL}$ in a total volume of $200 \mu \mathrm{L}$ per well, and incubated at $37^{\circ} \mathrm{C}$ for $24 \mathrm{~h}$. Cells were treated with varying concentrations of the appropriate compounds to yield the desired final concentration. Ethanol was used as a vehicle and cells were treated with $1 \%$ ethanol $(v / v)$ in all experiments. Plates were incubated for $72 \mathrm{~h}$ at $37^{\circ} \mathrm{C}+5 \% \mathrm{CO}_{2}$ after which Alamar Blue (Invitrogen, Carlsbad, CA, USA) was added to each well. The plates were incubated for a further $4 \mathrm{~h}$ without exposure to light. EMEM medium with the addition of Alamar Blue was used as a blank. Vehicle treated cells were considered to be $100 \%$ viable and the viabilities of each compound was calculated accordingly. Results were calculated using transformed data [Final Concentration $=$ Log 
(Final Concentration)] to plot a non-linear, sigmoidal dose response curve from which the relative $\mathrm{IC}_{50}$ values were determined.

\subsubsection{Lactate Dehydrogenase Assay for Measurement of Cytotoxicity}

In this assay, the release of cytoplasmic lactate dehydrogenase (LDH) is used as a measure of cell lysis. MCF-7 cells were seeded at a density of $1 \times 10^{4}$ cells/well in a 96-well plate and incubated for $24 \mathrm{~h}$. The cells were then dosed with $2 \mu \mathrm{L}$ volumes of the test compounds, over the concentration range $1 \mathrm{nM}-50 \mu \mathrm{M}$. Cytotoxicity was determined using the CytoTox 96 nonradioactive cytotoxicity assay (Promega, Madison, WI, USA) following the manufacturer's protocol [79].

\subsubsection{Estrogen Receptor Fluorescent Polarisation Assay}

Competitive binding affinity experiments were carried out using purified baculovirus-expressed human ER $\alpha$ and ER $\beta$ and fluoromone, a fluorescein labelled estrogen ligand. ER binding ability of the selected compounds was investigated using ER $\alpha$ and ER $\beta$ fluorescence based ER competitive assay kits supplied by Invitrogen $[67,68]$. The assay was performed using a protocol described by the manufacturer. The assay allows for high throughput screening of potential ER-subtype ligands. The selected compounds were screened using both the ER $\alpha$ and ER $\beta$ competitive assay kits. The protocol for carrying out the assay was similar for both ER subtypes. Principally, the main difference between the kits relates to the functional receptor concentration and the specific activity of the different ERs $[33,34]$. The recombinant ER and the fluorescent estrogen ligand were removed from the $-80^{\circ}$ freezer and thawed on ice $\left(4{ }^{\circ} \mathrm{C}\right)$ for $1 \mathrm{~h}$ prior to use. Previously prepared serial dilutions of the test compounds, consisting of the concentration range: $0.1 \mathrm{mM}, 10 \mu \mathrm{M}, 1 \mu \mathrm{M}, 100 \mathrm{nM}$ and $10 \mathrm{nM}$, were pipetted $(1 \mu \mathrm{L})$ into a 96-well Greiner black-bottomed multiwell plate. The final concentration in the well was diluted by two orders of magnitude. The concentration range of test compounds can be adjusted accordingly to best suit the assay. Each compound was repeated in duplicate. The ES2 screening buffer (100 mM potassium phosphate ( $\mathrm{pH} 7.4), 100 \mu \mathrm{g} / \mathrm{mL}$ bovine gamma-globulin and $0.02 \%$ sodium azide) was pipetted $(49 \mu \mathrm{L})$ into each well containing the test compounds. The amount of ER/Fluormone ${ }^{\mathrm{TM}} \mathrm{ES} 2$ complex was calculated based on a final reaction volume of $100 \mu \mathrm{L}$ per well, thus $50 \mu \mathrm{L}$ of complex was required per well. The complex was made up with ES2 screening buffer and was then pipetted $(50 \mu \mathrm{L})$ to the required wells. The controls used in the assay consisted of a well containing $100 \mu \mathrm{L}$ of screening buffer (no fluorescence expected), 50:50 complex/buffer (maximum polarisation), 1:49:50 ethanol(test sample diluent $) /$ complex $/$ buffer $(\sim$ maximum polarisation $=$ negative control) and 1:49:50 Estradiol $(10 \mu \mathrm{M}) /$ complex/buffer ( minimum polarisation = positive control). The plate was read on a BMG Pherastar fluorescence polarisation instrument with $485 \mathrm{~nm}$ excitation and $530 \mathrm{~nm}$ emission interference filters and processed using the Pherastar software. The plate was read over a $20 \mathrm{~min}$ period with polarisation readings taken every two minutes. The average of the polarisation readings was reported. Curve-fitting of the polarisation results were carried out using PRISM. The concentration of the test compound that results in a half-maximum shift in polarisation equals the $\mathrm{IC}_{50}$ of the test compound. The $\mathrm{IC}_{50}$ value is a measure of the relative binding affinity of the test compound for the ER.

\subsubsection{Flow Cytometry}

MCF-7 cells were seeded at a density of $5 \times 10^{4}$ cells/well in a 12-well plate and treated with the indicated compounds for $72 \mathrm{~h}$. Samples were then centrifuged at $650 \times \mathrm{g}$ for $5 \mathrm{~min}$ and resuspended in $100 \mu \mathrm{L}$ ice-cold PBS. Ice-cold 70\% $(v / v)$ ethanol $(1 \mathrm{~mL})$ was then added to fix the samples overnight at $4{ }^{\circ} \mathrm{C}$. Samples were subsequently centrifuged at $800 \times g$ for $10 \mathrm{~min}$ and resuspended in $200 \mu \mathrm{L}$ PBS. RNase A $(12.5 \mu \mathrm{L}$ of $10 \mathrm{mg} / \mathrm{mL})$ and propidium iodide $(37.5 \mu \mathrm{L}$ of $1 \mathrm{mg} / \mathrm{mL})$ were added to samples which were then incubated for $30 \mathrm{~min}$ at $37^{\circ} \mathrm{C}$. Cell cycle analysis was performed at $488 \mathrm{~nm}$ using a FACS Calibur flow cytometer (Becton Dickinson, Franklin Lakes, NJ, USA). The Macintosh-based 
application CellQuest was then used to analyse the data of 10,000 gated cells once cell debris had been excluded. Data points represent the mean \pm S.E.M. of three independent experiments.

\subsubsection{Generation of Human Peripheral Blood Mononuclear Cells}

Fresh peripheral blood was collected from healthy donors and diluted 1:3 with RPMI medium and added to half the equivalent volume of Lymphoprep. Samples were centrifuged at $750 \times g$ for $30 \mathrm{~min}$ to form a Ficoll gradient. The white buffy layer containing the peripheral blood mononuclear cells was removed, diluted to a volume of $50 \mathrm{~mL}$ with medium and centrifuged again for $10 \mathrm{~min}$ at $650 \times g$. Cells were then seeded at a density of $1 \times 10^{6}$ cells in $1 \mathrm{~mL}$ of RPMI medium supplemented with $10 \%$ FBS, $2 \mathrm{mM}$ L-glutamine and $100 \mathrm{U} / \mathrm{mL}$ penicillin and $100 \mu \mathrm{g} / \mathrm{mL}$ streptomycin.

\subsubsection{NCI One-Dose and Five-Dose Screen Output}

The NCI one-dose screen output is reported as a mean graph of the percent growth of treated cells and is similar in appearance to mean graphs generated in the 5-dose assay [80]. The value reported for the one-dose assay is growth relative to the no-drug control and relative to the time zero number of cells. The one-dose assay allows detection of growth inhibition (values between 0 and 100) and lethality (values less than 0). For example, a value of 100 means no growth inhibition. A value of 40 would mean $60 \%$ growth inhibition. A value of zero means no net growth over the course of the experiment. A value of -40 would mean $40 \%$ lethality. A value of -100 means all cells are dead. The results from the five-dose screen for 15a were manually entered into the COMPARE analysis software via an on-line submission form [80]. The results from the COMPARE analysis are retrievable on-line by searching using the relevant JobID reference number. The COMPARE analysis was run on a database of common anti-cancer agents (JobID: 37888) and the larger more comprehensive database including natural products and other submitted agents (JobID: 37889).

\subsection{Computational Details: Molecular Docking Study}

The 3ERT X-ray structure of hER $\alpha$ cocrystallized with 4-OHT was downloaded from the PDB Web site $[69,81]$. For ER $\beta$, the $1 \mathrm{NDE} X$-ray structure cocrystallized with the triazine ER $\beta$ modulator 4-(2-\{[4-\{[3-(4-chlorophenyl)-propyl]sulfanyl\}-6-(1-piperazinyl)-1,3,5-triazin-2-yl]amino\}ethyl)-phenol was downloaded [70]. Both were prepared using QuickPrep in MOE 2016.0802 [82]. Water molecules in proximity to the ligands were retained. The preprocessed X-ray structures were previously validated by our group [83]. Compounds were drawn in ChemBioDraw Ultra 13.0.2.3021 (PerkinElmer) and converted to sd files within Pipeline Pilot [BIOVIA, Dassault Systèmes, http://accelrys.com/products/collaborative-science/biovia-pipeline-pilot/]. MOE Dock was utilised for generation of the three compounds docking poses using default parameters with the exception of placing and refining 100 poses [82]. Over 300 conformers of each compound were generated stochastically in MOE for docking.

\section{Conclusions}

The estrogen receptors ER $\alpha$ and ER $\beta$ which modulate the effects of the estrogen hormones are important targets for design of chemotherapeutic agents whch target diseases such as breast cancer and osteoporosis. A series of novel conjugate molecules incorporating the ER ligands endoxifen and cyclofenil-endoxifen hybrids covalently linked to the antimitotic and tubulin targetting agent CA-4 were synthesised. These conjugates were evaluated as ER targeting ligands. A number of these compounds demonstrated pro-apoptotic effects, with significant antiproliferative activity in ER-positive MCF-7 breast cancer cell lines. These conjugates displayed potent binding affinity towards ER $\alpha$ and ER $\beta$ isoforms at nanomolar concentrations as determined by FP assay. The endoxifen conjugate $\mathbf{1 6 b}$ demonstrates antiproliferative activity in ER positive MCF-7 breast cancer cells $\left(\mathrm{IC}_{50}=5.7 \mathrm{nM}\right)$ and ER binding affinity to $\mathrm{ER} \alpha\left(\mathrm{IC}_{50}=52 \mathrm{nM}\right)$ and $\mathrm{ER} \beta\left(\mathrm{IC}_{50}=115 \mathrm{nM}\right)$. The conjugate 16a displayed significant growth inhibition effects on the NCI 60 cancer cell panel, suggesting 
that this compound may also inhibit cancer cell growth through non-ER dependent mechanisms. These conjugate compounds are identified as suitable lead compounds for future drug development based on favourable in vitro stability profile over $\mathrm{pH}$ range 4-9 and also in plasma. The conjugate 16a differs from $16 b$ only by a hydroxy functionality which is known to improve the binding of the ER-ligand fragment and is presumably the major factor in the 18-fold difference in antiproliferative potency. This is reinforced by the high affinity binding of $16 \mathbf{b}$ to ER $\alpha$ with an $\mathrm{IC}_{50} \mathrm{ER} \alpha$ of $52.1 \mathrm{nM}$. It remains unclear the exact role the combretastatin moiety has in the antiproliferative effect. These two conjugates $\mathbf{1 6 a}$ and $\mathbf{1 6 b}$ are covalently bound to the CA4 fragment by ester linkages which could be readily hydrolysed in vivo thus releasing the CA4. The compound 14a represents the cleaved endoxifen-linker component of conjugate 16a and displays very low antiproliferative activity. The intact conjugate may be exerting antiproliferative activity through binding in the ER resulting in the displacement of helix-12 and ER-antagonism. However, if the conjugate is cleaved the combretastatin may be exerting its antimitotic activity. Additionally, the conjugate may be working through both an ER-antagonistic pathway and antimitotic pathway i.e., through dual-action.

The cyclofenil-amide compound $\mathbf{1 3 e}$ is also identified as a promising lead compound of a clinically relevant ER conjugate with $\mathrm{IC}_{50}$ in MCF-7 cells of $187 \mathrm{nM}$, and ER binding affinity to $\mathrm{ER} \alpha\left(\mathrm{IC}_{50}=19 \mathrm{nM}\right)$ and $\mathrm{ER} \beta\left(\mathrm{IC}_{50}=229 \mathrm{nM}\right)$, which can target ER in the breast cancer cell and can thus deliver a cytotoxic agent CA4 to the cancer cell. Conjugate and bifunctional compounds which incorporate an ER ligand offer a useful method of delivering cytotoxic drugs to tissue sites such as breast cancers which express ERs. From the results obtained in the NCI 60 cell line assay, it is clear that compounds such as $\mathbf{1 6 a}$, although displaying nanomolar potency for MCF-7 ER positive cells and high affinity ER binding, do not display selectivity in activity towards the ER-expressing cell line MCF-7, indicating that 16a may also be modulating additional biological mechanisms (i.e., in promoting apoptosis or inhibition of tubulin polymerisation) other than via the ER alone. This result highlights possible therapeutic applications for these prototype ER-conjugates. Further research may determine the mechanism of antiproliferative action of these compounds in cancer cells. These conjugate compounds have potential application for further development as antineoplastic agents, (possibly modulating more than a single molecular target-in this case tubulin), in the treatment of both ER positive and ER negative breast cancers and these chemical classes of structures may be useful as scaffolds to be considered for multitarget drugs in future drug development studies.

\section{Appendix Supplementary Material}

The following are available online.

Acknowledgments: This study was supported by the Irish Research Council for Science, Engineering and Technology (IRCSET). Nuclear magnetic resonance spectroscopy was carried out by John O'Brien and Manuel Ruether at the School of Chemistry, Trinity College Dublin. The Trinity Biomedical Sciences Institute is supported by a capital infrastructure investment from Cycle 5 of the Irish Higher Education Authority's Programme for Research in Third Level Institutions (PRTLI). D.F. thanks the software vendors for their continuing support of academic research efforts, in particular the contributions of Biovia, the Chemical Computing Group, and OpenEye Scientific. The support and provisions of Dell Ireland, the Trinity Centre for High Performance Computing (TCHPC), and the Irish Centre for High-End Computing (ICHEC) are also gratefully acknowledged.

Author Contributions: Patrick M. Kelly synthesised and characterised the molecules in the studies according to Schemes 1, 2, 4 and 5, performed cell studies and generated the data in Tables 1, 2 and 4 and performed data analysis and interpreted data. Niall O. Keely synthesised and characterised the molecules in the studies in Scheme 6, performed the cell studies on these compounds and generated data in Tables 2 and 4. Sandra A. Bright performed biochemical experiments and generated the data in Figure 2. Gloria Ana synthesised compounds in Scheme 3, characterised these compounds, performed the cell studies and generated data in Table 2. Bassem Yassin performed the HPLC analytical study and the stability study. Daniela M. Zisterer assisted with the design of the biochemical studies. Darren Fayne performed the molecular modelling studies in Figures 3-5. Mary J. Meegan designed the studies, wrote drafts of the manuscript and submitted the manuscript.

Conflicts of Interest: The authors declare no conflict of interest. 


\section{References}

1. Jemal, A.; Siegel, R.; Xu, J.; Ward, E. Cancer statistics, 2010. CA Cancer J. Clin. 2010, 60, 277-300. [CrossRef] [PubMed]

2. Pasqualini, J.R.; Chetrite, G.S. Recent insight on the control of enzymes involved in estrogen formation and transformation in human breast cancer. J. Steroid Biochem. Mol. Biol. 2005, 93, 221-236. [CrossRef] [PubMed]

3. Nilsson, S.; Gustafsson, J.A. Estrogen receptors: Therapies targeted to receptor subtypes. Clin. Pharmacol. Ther. 2011, 89, 44-55. [CrossRef] [PubMed]

4. Jordan, V.C. Antiestrogens and selective estrogen receptor modulators as multifunctional medicines. 2. Clinical considerations and new agents. J. Med. Chem. 2003, 46, 1081-1111. [CrossRef] [PubMed]

5. Jordan, V.C. Antiestrogens and selective estrogen receptor modulators as multifunctional medicines. 1. Receptor interactions. J. Med. Chem. 2003, 46, 883-908. [CrossRef] [PubMed]

6. Meegan, M.J.; Lloyd, D.G. Advances in the science of estrogen receptor modulation. Curr. Med. Chem. 2003, 10, 181-210. [CrossRef] [PubMed]

7. Pettersson, K.; Gustafsson, J.A. Role of estrogen receptor beta in estrogen action. Annu. Rev. Physiol. 2001, 63, 165-192. [CrossRef] [PubMed]

8. Hartman, J.; Strom, A.; Gustafsson, J.A. Estrogen receptor beta in breast cancer-Diagnostic and therapeutic implications. Steroids 2009, 74, 635-641. [CrossRef] [PubMed]

9. Murphy, L.C.; Leygue, E. The role of estrogen receptor-beta in breast cancer. Semin. Reprod. Med. 2012, 30, 5-13. [PubMed]

10. Nelson, A.W.; Tilley, W.D.; Neal, D.E.; Carroll, J.S. Estrogen receptor beta in prostate cancer: Friend or foe? Endocr-Relat. Cancer 2014, 21, T219-T234. [CrossRef] [PubMed]

11. Christoforou, P.; Christopoulos, P.F.; Koutsilieris, M. The role of estrogen receptor beta in prostate cancer. Mol. Med. 2014, 20, 427-434. [CrossRef] [PubMed]

12. Bardin, A.; Boulle, N.; Lazennec, G.; Vignon, F.; Pujol, P. Loss of erbeta expression as a common step in estrogen-dependent tumor progression. Endocr.-Relat. Cancer 2004, 11, 537-551. [CrossRef] [PubMed]

13. Pike, A.C.W. Lessons learnt from structural studies of the oestrogen receptor. Best Pract. Res. Clin. Endocrinol. Metab. 2006, 20, 1-14. [CrossRef] [PubMed]

14. Ascenzi, P.; Bocedi, A.; Marino, M. Structure-function relationship of estrogen receptor alpha and beta: Impact on human health. Mol. Asp. Med. 2006, 27, 299-402. [CrossRef] [PubMed]

15. Enmark, E.; Pelto-Huikko, M.; Grandien, K.; Lagercrantz, S.; Lagercrantz, J.; Fried, G.; Nordenskjold, M.; Gustafsson, J.A. Human estrogen receptor beta-gene structure, chromosomal localization, and expression pattern. J. Clin. Endocrinol. Metab. 1997, 82, 4258-4265. [PubMed]

16. Maximov, P.Y.; Lee, T.M.; Jordan, V.C. The discovery and development of selective estrogen receptor modulators (serms) for clinical practice. Curr. Clin. Pharmacol. 2013, 8, 135-155. [CrossRef] [PubMed]

17. Heringa, M. Review on raloxifene: Profile of a selective estrogen receptor modulator. Int. J. Clin. Pharmacol. Ther. 2003, 41, 331-345. [CrossRef] [PubMed]

18. Jordan, V.C. New insights into the metabolism of tamoxifen and its role in the treatment and prevention of breast cancer. Steroids 2007, 72, 829-842. [CrossRef] [PubMed]

19. Morrow, M.; Jordan, V.C. The current status of breast cancer chemoprevention: A star is born. J. Surg. Oncol. 2007, 95, 4-5. [CrossRef] [PubMed]

20. Robertson, J.F. Selective oestrogen receptor modulators/new antioestrogens: A clinical perspective. Cancer Treat. Rev. 2004, 30, 695-706. [CrossRef] [PubMed]

21. Gruber, C.; Gruber, D. Bazedoxifene (Wyeth). Curr. Opin. Investig. Drugs 2004, 5, 1086-1093. [PubMed]

22. Soe, L.H.; Wurz, G.T.; Kao, C.J.; Degregorio, M.W. Ospemifene for the treatment of dyspareunia associated with vulvar and vaginal atrophy: Potential benefits in bone and breast. Int. J. Womens Health 2013, 5, 605-611. [PubMed]

23. Johnston, S.J.; Cheung, K.L. Fulvestrant-A novel endocrine therapy for breast cancer. Curr. Med. Chem. 2010, 17, 902-914. [CrossRef] [PubMed]

24. Willson, T.M.; Henke, B.R.; Momtahen, T.M.; Charifson, P.S.; Batchelor, K.W.; Lubahn, D.B.; Moore, L.B.; Oliver, B.B.; Sauls, H.R.; Triantafillou, J.A.; et al. 3-[4-(1,2-Diphenylbut-1-enyl)phenyl]acrylic acid: A non-steroidal estrogen with functional selectivity for bone over uterus in rats. J. Med. Chem. 1994, 37, 1550-1552. [CrossRef] [PubMed] 
25. Wu, Y.L.; Yang, X.; Ren, Z.; McDonnell, D.P.; Norris, J.D.; Willson, T.M.; Greene, G.L. Structural basis for an unexpected mode of serm-mediated er antagonism. Mol. Cell 2005, 18, 413-424. [CrossRef] [PubMed]

26. Teft, W.A.; Mansell, S.E.; Kim, R.B. Endoxifen, the active metabolite of tamoxifen, is a substrate of the efflux transporter p-glycoprotein (multidrug resistance 1). Drug Metab. Dispos. Biol. Fate Chem. 2011, 39, 558-562. [CrossRef] [PubMed]

27. Wu, X.; Hawse, J.R.; Subramaniam, M.; Goetz, M.P.; Ingle, J.N.; Spelsberg, T.C. The tamoxifen metabolite, endoxifen, is a potent antiestrogen that targets estrogen receptor alpha for degradation in breast cancer cells. Cancer Res. 2009, 69, 1722-1727. [CrossRef] [PubMed]

28. Lim, Y.C.; Li, L.; Desta, Z.; Zhao, Q.; Rae, J.M.; Flockhart, D.A.; Skaar, T.C. Endoxifen, a secondary metabolite of tamoxifen, and 4-oh-tamoxifen induce similar changes in global gene expression patterns in mcf-7 breast cancer cells. J. Pharmacol. Exp. Ther. 2006, 318, 503-512. [CrossRef] [PubMed]

29. Lu, W.J.; Desta, Z.; Flockhart, D.A. Tamoxifen metabolites as active inhibitors of aromatase in the treatment of breast cancer. Breast Cancer Res. Treat. 2012, 131, 473-481. [CrossRef] [PubMed]

30. Burke, P.J.; Koch, T.H. Design, synthesis, and biological evaluation of doxorubicin-formaldehyde conjugates targeted to breast cancer cells. J. Med. Chem. 2004, 47, 1193-1206. [CrossRef] [PubMed]

31. Keely, N.O.; Carr, M.; Yassin, B.; Ana, G.; Lloyd, D.G.; Zisterer, D.; Meegan, M.J. Design, synthesis and biochemical evaluation of novel selective estrogen receptor ligand conjugates incorporating an endoxifen-combretastatin hybrid scaffold. Biomedicines 2016, 4, E15. [CrossRef] [PubMed]

32. Kieser, K.J.; Kim, D.W.; Carlson, K.E.; Katzenellenbogen, B.S.; Katzenellenbogen, J.A. Characterization of the pharmacophore properties of novel selective estrogen receptor downregulators (serds). J. Med. Chem. 2010, 53, 3320-3329. [CrossRef] [PubMed]

33. Seo, J.W.; Comninos, J.S.; Chi, D.Y.; Kim, D.W.; Carlson, K.E.; Katzenellenbogen, J.A. Fluorine-substituted cyclofenil derivatives as estrogen receptor ligands: Synthesis and structure-affinity relationship study of potential positron emission tomography agents for imaging estrogen receptors in breast cancer. J. Med. Chem. 2006, 49, 2496-2511. [CrossRef] [PubMed]

34. Bai, L.; Zhu, R.; Chen, Z.; Gao, L.; Zhang, X.; Wang, X.; Bai, C. Potential role of short hairpin rna targeting epidermal growth factor receptor in growth and sensitivity to drugs of human lung adenocarcinoma cells. Biochem. Pharmacol. 2006, 71, 1265-1271. [CrossRef] [PubMed]

35. Corson, T.W.; Aberle, N.; Crews, C.M. Design and applications of bifunctional small molecules: Why two heads are better than one. ACS Chem. Biol. 2008, 3, 677-692. [CrossRef] [PubMed]

36. Jaracz, S.; Chen, J.; Kuznetsova, L.V.; Ojima, I. Recent advances in tumor-targeting anticancer drug conjugates. Bioorg. Med. Chem. 2005, 13, 5043-5054. [CrossRef] [PubMed]

37. Dao, K.L.; Hanson, R.N. Targeting the estrogen receptor using steroid-therapeutic drug conjugates (hybrids). Bioconj. Chem. 2012, 23, 2139-2158. [CrossRef] [PubMed]

38. Keely, N.O.; Meegan, M.J. Design, synthesis and biochemical evaluation of estrogen receptor ligand conjugates as tumor targeting agents. Lett. Drug Des. Discov. 2012, 9, 295-304. [CrossRef]

39. Kelly, P.M.; Bright, S.A.; Fayne, D.; Pollock, J.K.; Zisterer, D.M.; Williams, D.C.; Meegan, M.J. Synthesis, antiproliferative and pro-apoptotic activity of 2-phenylindoles. Bioorg. Med. Chem. 2016, 24, 4075-4099. [CrossRef] [PubMed]

40. Keely, N.O.; Meegan, M.J. Targeting tumors using estrogen receptor ligand conjugates. Curr. Cancer Drug Targets 2009, 9, 370-380. [CrossRef] [PubMed]

41. Pettit, G.R.; Temple, C., Jr.; Narayanan, V.L.; Varma, R.; Simpson, M.J.; Boyd, M.R.; Rener, G.A.; Bansal, N. Antineoplastic agents 322. Synthesis of combretastatin a-4 prodrugs. Anti-Cancer Drug Des. 1995, 10, $299-309$.

42. McGown, A.T.; Fox, B.W. Differential cytotoxicity of combretastatins a1 and a4 in two daunorubicin-resistant p388 cell lines. Cancer Chemother. Pharmacol. 1990, 26, 79-81. [CrossRef] [PubMed]

43. Hsieh, H.P.; Liou, J.P.; Mahindroo, N. Pharmaceutical design of antimitotic agents based on combretastatins. Curr. Pharm. Des. 2005, 11, 1655-1677. [CrossRef] [PubMed]

44. Clinicaltrials. Gov. A Service of the U.S. National Institutes of Health. Available online: http://www. Clinicaltrials.Gov/ct2/show / nct02055690?Term=fosbretabulin\&rank=1 (accessed on 8 June 2017).

45. Tron, G.C.; Pirali, T.; Sorba, G.; Pagliai, F.; Busacca, S.; Genazzani, A.A. Medicinal chemistry of combretastatin a4: Present and future directions. J. Med. Chem. 2006, 49, 3033-3044. [CrossRef] [PubMed]

46. Zhang, R.L.; Li, Y.; Zhang, M.; Tang, Q.W.; Zhang, X. Hypoxia-responsive drug-drug conjugated nanoparticles for breast cancer synergistic therapy. RSC Adv. 2016, 6, 30268-30276. [CrossRef] 
47. Ishikawa, K.K.M.; Masuda, A.; Takashio, K. Polymer Conjugate of Combretastatin, pct/jp2007/063990. EP Patent 2,042,195, 2009.

48. Sumer Bolu, B.; Manavoglu Gecici, E.; Sanyal, R. Combretastatin a-4 conjugated antiangiogenic micellar drug delivery systems using dendron-polymer conjugates. Mol. Pharm. 2016, 13, 1482-1490. [CrossRef] [PubMed]

49. Parihar, S.; Kumar, A.; Chaturvedi, A.K.; Sachan, N.K.; Luqman, S.; Changkija, B.; Manohar, M.; Prakash, O.; Chanda, D.; Khan, F.; et al. Synthesis of combretastatin a4 analogues on steroidal framework and their anti-breast cancer activity. J. Steroid Biochem. Mol. Biol. 2013, 137, 332-344. [CrossRef] [PubMed]

50. Gaukroger, K.; Hadfield, J.A.; Hepworth, L.A.; Lawrence, N.J.; McGown, A.T. Novel syntheses of cis and trans isomers of combretastatin a-4. J. Org. Chem. 2001, 66, 8135-8138. [CrossRef] [PubMed]

51. Zou, Y.; Xiao, C.F.; Zhong, R.Q.; Wei, W.; Huang, W.M.; He, S.J. Synthesis of combretastatin a-4 and erianin. J. Chem. Res. 2008, 354-356. [CrossRef]

52. Pettit, G.R.; Singh, S.B.; Boyd, M.R.; Hamel, E.; Pettit, R.K.; Schmidt, J.M.; Hogan, F. Antineoplastic agents. 291. Isolation and synthesis of combretastatins a-4, a-5, and a-6(1a). J. Med. Chem. 1995, 38, 1666-1672. [CrossRef] [PubMed]

53. Coe, P.L.; Scriven, C.E. Crossed coupling of functionalized ketones by low valent titanium (the mcmurry reaction)-A new stereoselective synthesis of tamoxifen. J. Chem. Soc. Perkin Trans 1 1986, 475-477. [CrossRef]

54. Fauq, A.H.; Maharvi, G.M.; Sinha, D. A convenient synthesis of (Z)-4-Hydroxy-N-desmethyltamoxifen (endoxifen). Bioorg. Med. Chem. Lett. 2010, 20, 3036-3038. [CrossRef] [PubMed]

55. Maximov, P.Y.; Myers, C.B.; Curpan, R.F.; Lewis-Wambi, J.S.; Jordan, V.C. Structure-function relationships of estrogenic triphenylethylenes related to endoxifen and 4-hydroxytamoxifen. J. Med. Chem. 2010, 53, 3273-3283. [CrossRef] [PubMed]

56. Katzenellenbogen, J.A.; Carlson, K.E.; Katzenellenbogen, B.S. Facile geometric isomerization of phenolic non-steroidal estrogens and antiestrogens: Limitations to the interpretation of experiments characterizing the activity of individual isomers. J. Steroid Biochem. 1985, 22, 589-596. [CrossRef]

57. Lim, Y.C.; Desta, Z.; Flockhart, D.A.; Skaar, T.C. Endoxifen (4-Hydroxy-N-desmethyl-tamoxifen) has anti-estrogenic effects in breast cancer cells with potency similar to 4-Hydroxy-tamoxifen. Cancer Chemother. Pharmacol. 2005, 55, 471-478. [CrossRef] [PubMed]

58. Sinha, A.K.; Sharma, A.; Joshi, B.P. One-pot two-step synthesis of 4-vinylphenols from 4-hydroxy substituted benzaldehydes under microwave irradiation: A new perspective on the classical knoevenagel-doebner reaction. Tetrahedron 2007, 63, 960-965. [CrossRef]

59. Sinha, A.K.; Joshi, B.P.; Sharma, A.; Kumar, J.K.; Kaul, V.K. Microwave-assisted rapid synthesis of methyl 2,4,5-trimethoxyphenylpropionate, a metabolite of cordia alliodora. Nat. Prod. Res. 2003, 17, 419-422. [CrossRef] [PubMed]

60. Bidlack, J.M.; Lockshin, R.A. Evolution of ldh isozymes during programmed cell death. Comp. Biochem. Physiol. B 1976, 55, 161-166. [CrossRef]

61. Flynn, B.L.; Flynn, G.P.; Hamel, E.; Jung, M.K. The synthesis and tubulin binding activity of thiophene-based analogues of combretastatin a-4. Bioorg. Med. Chem. Lett. 2001, 11, 2341-2343. [CrossRef]

62. Dark, G.G.; Hill, S.A.; Prise, V.E.; Tozer, G.M.; Pettit, G.R.; Chaplin, D.J. Combretastatin a-4, an agent that displays potent and selective toxicity toward tumor vasculature. Cancer Res. 1997, 57, 1829-1834. [PubMed]

63. De Martino, G.; La Regina, G.; Coluccia, A.; Edler, M.C.; Barbera, M.C.; Brancale, A.; Wilcox, E.; Hamel, E.; Artico, M.; Silvestri, R. Arylthioindoles, potent inhibitors of tubulin polymerization. J. Med. Chem. 2004, 47, 6120-6123. [CrossRef] [PubMed]

64. Reddel, R.R.; Murphy, L.C.; Hall, R.E.; Sutherland, R.L. Differential sensitivity of human breast cancer cell lines to the growth-inhibitory effects of tamoxifen. Cancer Res. 1985, 45, 1525-1531. [PubMed]

65. Johnson, M.D.; Zuo, H.; Lee, K.H.; Trebley, J.P.; Rae, J.M.; Weatherman, R.V.; Desta, Z.; Flockhart, D.A.; Skaar, T.C. Pharmacological characterization of 4-Hydroxy- $N$-desmethyl tamoxifen, a novel active metabolite of tamoxifen. Breast Cancer Res. Treat. 2004, 85, 151-159. [CrossRef] [PubMed]

66. Popsavin, M.; Torovic, L.; Svircev, M.; Kojic, V.; Bogdanovic, G.; Popsavin, V. Synthesis and antiproliferative activity of two new tiazofurin analogues with 2'-amido functionalities. Bioorg. Med. Chem. Lett. 2006, 16, 2773-2776. [CrossRef] [PubMed]

67. Polarscreen ${ }^{\mathrm{TM}}$ er Alpha Competitor Assay, Green. 2016. Available online: https://tools.Thermofisher.Com/ content/sfs/manuals/polarscreen_er_alpha_green_man.Pdf (accessed on 10 June 2017). 
68. Polarscreen ${ }^{\mathrm{TM}}$ er Beta Competitor Assay Kit, Green. 2016. Available online: https://tools. Thermofisher. Com/content/sfs / manuals / polarscreen_er_beta_green_man.Pdf (accessed on 10 June 2017).

69. Shiau, A.K.; Barstad, D.; Loria, P.M.; Cheng, L.; Kushner, P.J.; Agard, D.A.; Greene, G.L. The structural basis of estrogen receptor/coactivator recognition and the antagonism of this interaction by tamoxifen. Cell 1998, 95, 927-937. [CrossRef]

70. Henke, B.R.; Consler, T.G.; Go, N.; Hale, R.L.; Hohman, D.R.; Jones, S.A.; Lu, A.T.; Moore, L.B.; Moore, J.T.; Orband-Miller, L.A.; et al. A new series of estrogen receptor modulators that display selectivity for estrogen receptor beta. J. Med. Chem. 2002, 45, 5492-5505. [CrossRef] [PubMed]

71. Borrel, C.; Thoret, S.; Cachet, X.; Guenard, D.; Tillequin, F.; Koch, M.; Michel, S. New antitubulin derivatives in the combretastatin a4 series: Synthesis and biological evaluation. Bioorg. Med. Chem. 2005, 13, 3853-3864. [CrossRef] [PubMed]

72. Wang, J.; Zhang, C.L.; Wang, T.J.; Li, X.F. Synthesis of resveratrol analogs/stilbene derivatives and their nitric oxide inhibitory and radical scavenging activities. Chem. Res. Chin. Univ. 2014, 30, 941-946. [CrossRef]

73. Letcher, R.M.; Nhamo, L.R.M.; Gumiro, I.T. Chemical constituents of combretaceae. 2. Substituted phenanthrenes and 9,10-dihydrophenanthrenes and a substituted bibenzyl from heartwood of combretum-molle. J. Chem. Soc. Perkin Trans. 1 1972, 206-210. [CrossRef]

74. Song, S.; Li, X.; Guo, J.; Hao, C.; Feng, Y.; Guo, B.; Liu, T.; Zhang, Q.; Zhang, Z.; Li, R.; et al. Design, synthesis and biological evaluation of 1-phenanthryl-tetrahydroisoquinoline derivatives as novel p21-activated kinase 4 (pak4) inhibitors. Org. Biomol. Chem. 2015, 13, 3803-3818. [CrossRef] [PubMed]

75. Zou, Y.; Huang, Q.; Huang, T.K.; Ni, Q.C.; Zhang, E.S.; Xu, T.L.; Yuan, M.; Li, J. Cui/1,10-phen/peg promoted decarboxylation of 2,3-diarylacrylic acids: Synthesis of stilbenes under neutral and microwave conditions with an in situ generated recyclable catalyst. Org. Biomol. Chem. 2013, 11, 6967-6974. [CrossRef] [PubMed]

76. Cushman, M.; Nagarathnam, D.; Gopal, D.; He, H.M.; Lin, C.M.; Hamel, E. Synthesis and evaluation of analogues of (Z)-1-(4-Methoxyphenyl)-2-(3,4,5-trimethoxyphenyl)ethene as potential cytotoxic and antimitotic agents. J. Med. Chem. 1992, 35, 2293-2306. [CrossRef] [PubMed]

77. Prakash, S.; Khan, M.A.; Khan, K.Z.; Zaman, A. Stilbenes of gnetum-ula. Phytochemistry 1985, $24,622-624$. [CrossRef]

78. GraphPad Prism. Available online: https://www.graphpad.com/scientific-software/prism/ (accessed on 29 August 2017).

79. Fisher Scientific. Promega CytoTox96 NonRadioactive Cytotoxicity Assay. Available online: https: / www.fishersci.com/shop/products/promega-cytotox-96-nonradioactive-cytotoxicity-assaycytotox-96-cytotoxicity-assay/prg1780 (accessed on 29 August 2017).

80. Welcome to the Developmental Therapeutics Program. National Cancer Institute, Bethesda, MD., 2016. Available online: Http:/ / dtp.Cancer.Gov (accessed on 10 June 2017).

81. Rcsb Protein Data Bank. Available online: Http://www.Rcsb.Org/ (accessed on 10 June 2017).

82. Molecular Operating Environment Chemical Computing Group. Available online: https://www.chemcomp. com/MOE-Molecular_Operating_Environment.htm (accessed on 29 August 2017).

83. O’Boyle, N.M.; Barrett, I.; Greene, L.M.; Carr, M.; Fayne, D.; Twamley, B.; Knox, A.J.S.; Keely, N.O.; Zisterer, D.M.; Meegan, M.J. Lead optimization of benzoxepin-type selective estrogen receptor (er) modulators and downregulators with subtype-specific eralpha and erbeta activity. J. Med. Chem. 2017. [CrossRef] [PubMed]

Sample Availability: Sample Availability: Samples of the compounds 3i, 11c, 11d, 11e, 13e, 14c, 16b and 16c are available from the authors.

(C) 2017 by the authors. Licensee MDPI, Basel, Switzerland. This article is an open access article distributed under the terms and conditions of the Creative Commons Attribution (CC BY) license (http:/ / creativecommons.org/licenses/by/4.0/). 